BEACH EROSION BOARD

OFFICE OF THE CHIEF OF ENGINEERS

\title{
LITTORAL STUDIES \\ NEAR SAN FRANCISCO \\ USING TRACER TECHNIQUES
}

TECHNICAL MEMORANDUM NO. 131

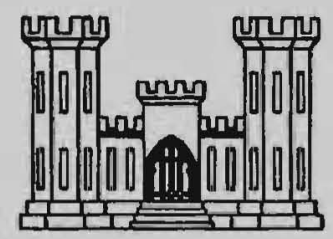




\section{LITTORAL STUDIES \\ NEAR SAN FRANCISCO \\ USING TRACER TECHNIQUES}

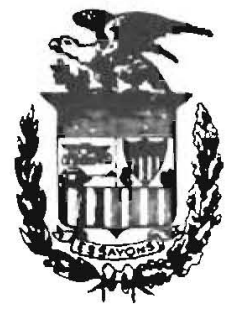

TECHNICAL MEMORANDUM NO. 131

BEACH EROSION BOARD

CORPS OF ENGINEERS

NOVEMBER 1962

LIMITED FREE DISTRIBUTION OF THIS PUBLICATION WITHIN THE UNITED STATES IS MADE BY THE BEACH EROSION BOARD, 5201 LITTLE FALLS ROAD, N. W., WASHINGTON 16, D. C. 


\section{POREWORD}

Differences in concentrations of mineral composition of beach areas along the shoreline have on occasion been used to estimate direction of movement of littoral drift and other littoral processes. Extension of the se methods to the use of naturally radioactive thorium as a means of detecting direction of littoral drift has been made over a portion of the California coast from the Russian River to Point San Fedro. This report discusses the se methods and the results which indicate the method to be rathe $r$ quick for qualitative results and quite simple compared to normal mineralogical analysis. After separation of the heavy mineral fraction from samples taken along the beaches, radioactivity present is determined by use of a two-channe 1 gamma-ray spectrometer with one channe 1 adjusted on the 0.238 mev. peak from $\mathrm{P}_{\mathrm{b}} 212$ in the thorium series and the other on the 0.118 mev. peak from $\mathrm{Ra}^{226}$ in the uranium series. As the method and its results appear of considerable interest in the field of beach erosion and shore processes, it is now being published as a Beach Erosion Board Technical Memorandum.

This report was prepared at the Wave Research Laboratory of the Institute of Engineering Research at the University of California. Much of the work was done under support by the National Science Foundation (Grant G-18123) but use was also made of data gathered concurrently by the University in pursuance of Contract DA-49-055Eng-8 with the Beach Erosion Board for the study of beach materials and sources of beach materials along the California coast. The author of the report, Adel kamel, was at that time a candidate for a doctoral degree at the University (in fact this report formed in part his $\mathrm{Ph}$. D. thesis) and is now a research engineer and assistant professor at the Coastal Engineering Laboratory, University of Plorida.

Views and conclusions stated in this report a re not necessarily those of the Beach Erosion Board.

This report is published under authority of Public Law 166, 79 th Congress, approved July 31, 1945. 
TABLE OF CONTENTS

$\underline{\text { Page }}$

List of figures

i1

ABSTRACT

1

INTRODUCTION

2

General problem

2

Summary of past studies on littoral drift

PRINCIPALS OP NATURAL RADIOACTIVITY

INVESTIGATIONAL PROCEDURE

ANALYSIS OF RESULTS

21

SUMMARY AND CONCLUS IONS

36

ACK NOWLEDGEMENTS

39

B IBL IOGRAPHY

40

Appendix I - EXPERIMENTAL EQUIPMENT

45

Appendix II - ADJUSTING THE GAMMA-RAY SPECTROMETER

50

Appendix III - CORRECTION POR SAMPLE SIZE

56

Appendix IV - TABLES OF EXPERIMENTAL RESULTS

60 


\section{List of Figures}

Figure

Page

1 Waves breaking at an angle with beach generate longshore currents; north of Oceanside, California

2 Gamma-ray spectrometer for $\mathrm{K}_{2} \mathrm{CO}_{3}$

3 Gamma-ray spectrum for vo

4 Gamma-ray spectrum for Th 0

5a Gama-ray spectrum for a sand sample before separating its heavy minerals by bromof orm

5b Gamma-ray spectrum for the heavy minerals af ter separation by bromoform

6 Counting channels for thorium and uranium

7 Number and location of samples, their thorium and heavy minerals concentration

8 Number and location of samples from north of the Russian River mouth to Bodega Head, their thorium and heavy minerals concentration, and the direction of littoral drift

9 Number and location of samples from Bodega Head to Tomales point, their thorium and heavy minerals concentration, and the direction of littoral drift

10 Number and location of samples for Point Reyes Beach and Drakes Bay, the ir thorium and heavy minerals concentration, and the direction of littoral drift

11 Number and location of samples for Bolinas Bay and San Francisco Bar, the ir thorium and heavy minerals concentration, and the direction of littoral drift

12 Number and location of samples south of the Golden Gate, their thorium and heavy minerals concentration, and the direction of littoral drift

13 Variation of thorium and heavy minerals concentration along a profile of Drakes Bay 
Figure

Page

14 Variation in thorium and heavy mine rals concentration with time at Ocean Beach in front of Fleishhacke $\mathrm{Zoo}$, San Francisco

15 Wave refraction diagrams for the reach under study

16 The direction of littoral drift and the sources of thorium 35 (streams and rocks) for the reach under study 35

17 Components of a 2-channel gamma-ray spectrometer 48

18 General view of the gamma-ray spectrometer used 49

19 Relationship between the anode volt dial and photomultiplier scale. 51

$20 \quad$ Gamma-ray spectra for standards 52

21 Relationship between the energy of the photon peak and the anode dial reading at which the peak appears 53

22 Thorium and uranium peaks counting at the same dial 1

23 Correction coefficient due to sample size 57

24 Rffect of sample size on counting rate 58 
LITTORAL STUDIES NEAR SAN FRANCISCO

US ING TRACER TBCHNIQUES

by

Ade1 M. Kame1, University of California

\section{ABST RACT}

A method of assaying for naturally radioactive thorium as a means of detecting the direction of littoral drift of sand along a sea coast was investigated and applied to the portion of the Coast of California from the Russian River mouth to Point San Pedro. The method proved to be very quick for qualitative results and rather simple compared to mineralogical analyses.

The method involved the collection of surface and deep samples along the reach of the coast under study. The heavy minerals for a limited size fraction of the sand samples were separated by bromoform and the radioactivity present in them was counted by the use of a two channel gamma-ray spectrometer. One channel was adjusted on the 0.238 mev. peak from $\mathrm{Pb}^{212}$ in the thorium serles and the other on the 0.118 mev. peak from $\mathrm{Ra}^{226}$ in the uranium series.

In this study the three factors considered in determining the direction of littoral drift along the coast were as follows:

1. The concentration of thorium (in parts per million) in the heavy minerals of a limited size fraction of the sand samples analyzed.

2. The percent of heavy minerals in the same size fraction used in ( 1 ).

3. Wave refraction diagrams.

A decrease in the concentration of thorium and heavy minerals from the source area indicated alongshore drift in the direction of decrease of both parameters, while wave refraction patterns showed a littoral sand drift in the direction of the alongshore energy component of waves breaking at an angle to the shore.

Based on the distribution of beach sand samples and the ir thorium and heavy minerals concentrations and wave refraction diagrams, the pattern of sand movement along the California Coast from the mouth of the Russian River to Point San Pedro was found to be from the north to the south except for a few locations where a reversal direction of littoral drift existed. 


\section{INTRODUCTION}

\section{Genera 1 Problem}

The source, movement, and deposition of sediments along shorelines have been studied extensively by geologists, geographers, and engineers. Johnson (1959*), defined the factors involved in the supply and loss of sand to a coast as follows:

Source of sand supply: (a) Major streams, (b) sma11 streams and gullies, (c) cliff e rosion and slides, (d) onshore movement of sand by wave action, and (e) wind action.

Sand losses: (a) Movement of $f$ shore into deep water, (b) losses into submarine canyons, (c) accretion against 1ittoral barriers, (d) removal of sand for construction purposes, (e) wind action, and ( $f$ ) abrasion by wave action.

The process by which sediments are moved along the shore is known as $11 t$ tora 1 drift and it includes beach drifting and alongshore drift (Johnson, 1919). Coarse material is moved along a foreshore in zigzag paths under the influence of swash and backwash of the waves. The process of alongshore drift is due to alongshore currents set up within the breaker zone by breaking waves approaching the shoreline at an angle (Pig. 1). Although the waves tend to become parallel to the coast as a result of refraction, they usua1ly break at a slight angle to the shore with the result that a littoral current is induced and is effective in moving a mass of wate $r$ (and the sediment placed in suspension by the breaking waves) slowly along the coast. It is this current combined with the agitating action of the breaking waves, that is the primary factor in causing movement of sand along a coastiine. It is believed that the largest percentage of the littoral transport occurs shoreward of the breaking point of the waves.

Knowledge of sand sources and direction of littoral drift along a coast are of prime importance in beach erosion studies. The se factors may be determined broadly by several distinct methods of approach, some of which are necessarily complementary to each other. The se include:

(1) The use of standard hydrographic methods of mapping the sea bed and shoreline, aerial surveys, wave data, and refraction diagram analyses, current measurements, sampling of suspended load and bed load sediments, etc.

(2) The use of natura 1 tracers such as heavy mineral fractions or she11 inclusions in sediment samples, in relation to their source areas.

(3) The use of radioisotopes as tracers for labeling sediment samples, either by incorporation of the activated material in artificial sediment, or by chemical or physical adhesion as a radioactive film on the particles of the real sediment, or by embedment within the particles (in the case of pebbles).

*See references p. 40 


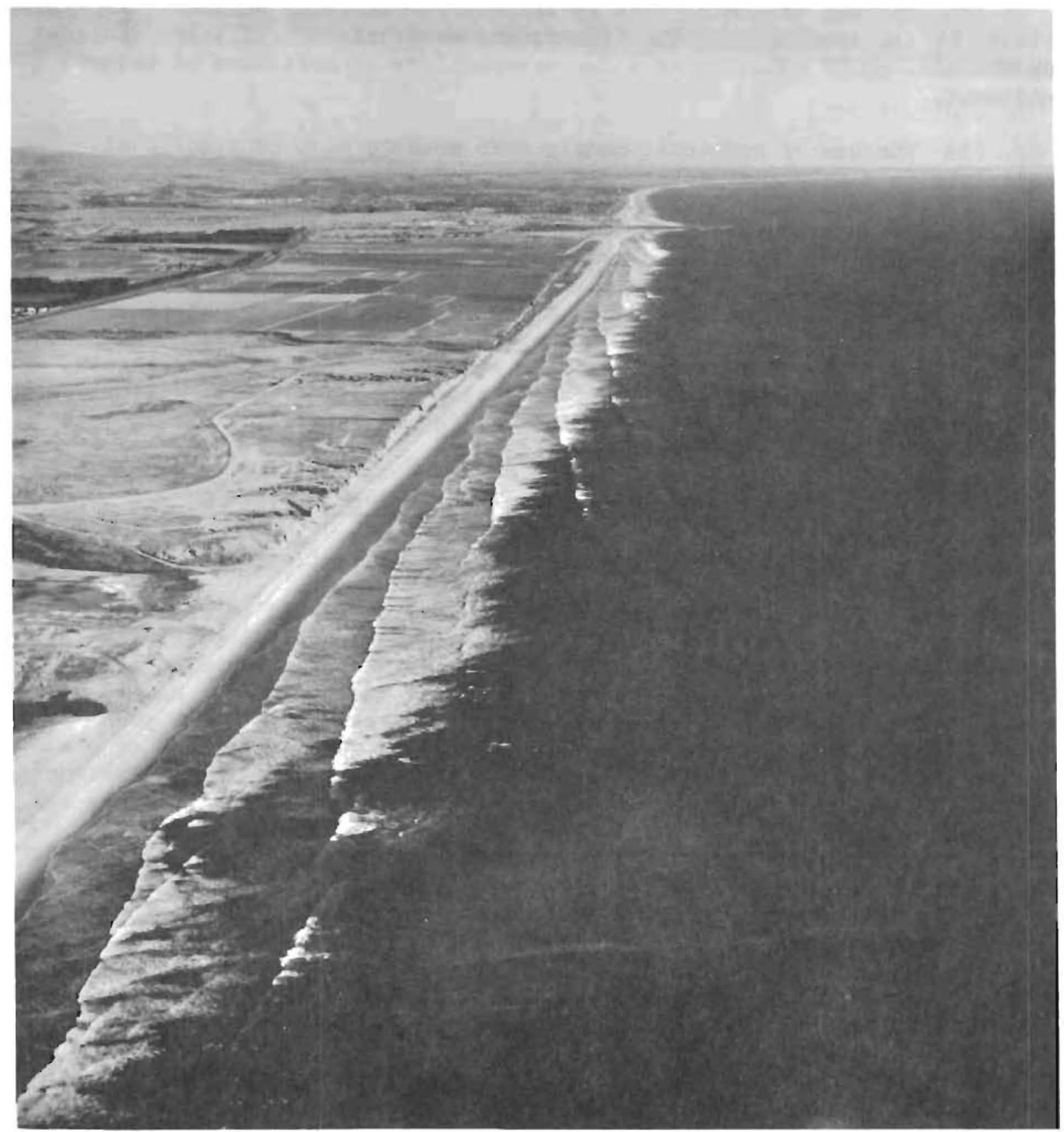

HYD-タ9O9

Waves breaking at an angle with beach generate longshore currents; north of Oceanside, California.

Fig. 1 
(4) The use of luminophors as tracers for labeling sediment samples, either by incorporation of the fluorescent material in artificial sediment or shingle, or by adhesion as a luminescent film on particles of natural sediment.

(5) The use of hydraulic models with movable beds of artificial materials to simulate prototype sediment processes.

Along the California Coast, a method of using radioactive tracers presented itself in that the re a re several locations on the coast where radioactive material is added naturally to the beaches. This material is thorlum ( $\mathrm{Th}^{232}, 0.238 \mathrm{mev}$.). It is added at discrete places along the coast where rivers flowing through thorium-rich granite outcrops reach the coast or whe re the thorium-rich granite itself outcrops at the seacoast. This thorium was used as a means of detecting the direction of 1 ittora 1 drift of sand along the portion of the California Coast from the Russian River mouth to Point San Pedro.

\section{Summary of Past Studies on Littora1 Drift}

Formulas for rate of littoral drift:

Many attempts have been made to determine the amount of material migrating along a shoreline. The principal factors affecting the rate of 1ittoral transport have been studied in the laboratory (K rumbein, 1944; Savi11e, 1950; Johnson, 1952; Sauvage De Saint Marc; 1955). However, complete understanding of the problem is still lacking, although such information is of utmost importance in the design and development of navigation channels, ports, and beaches. Advance towards a better understanding of this problem has been made in recent years, but the effect of waves and currents on littoral drift still defies accurate prediction of certain phenomenon. Existing formulas for estimating the amount of littoral drift a11 are of a semi-theoretical or entirely empirical nature inasmuch as some of the physical elements are not completely understood. Some of the more common formulas are:

1 - The Los Angeles formula (1937):

$$
Q=1 / 2 K_{1} \text { We } \sin 2 \alpha
$$

2 - Baton (1951) gave the formula (identical to formula 1 above):

$$
\mathrm{Q}=\mathrm{K} \text { we } \sin a_{\mathrm{b}} \cos a_{\mathrm{b}}
$$

3 - Caldwe11 (1956) gave the formula:

$$
Q=210 E^{0.8} \quad \text { where: } E=E_{t} \sin \varphi \cos \varphi
$$

4 - Bajorunas (1961) gave the formula:

$$
Q=a E_{0}^{n} \sin \alpha_{0}\left[1-e^{-b D \cot \alpha_{0}}\right]
$$




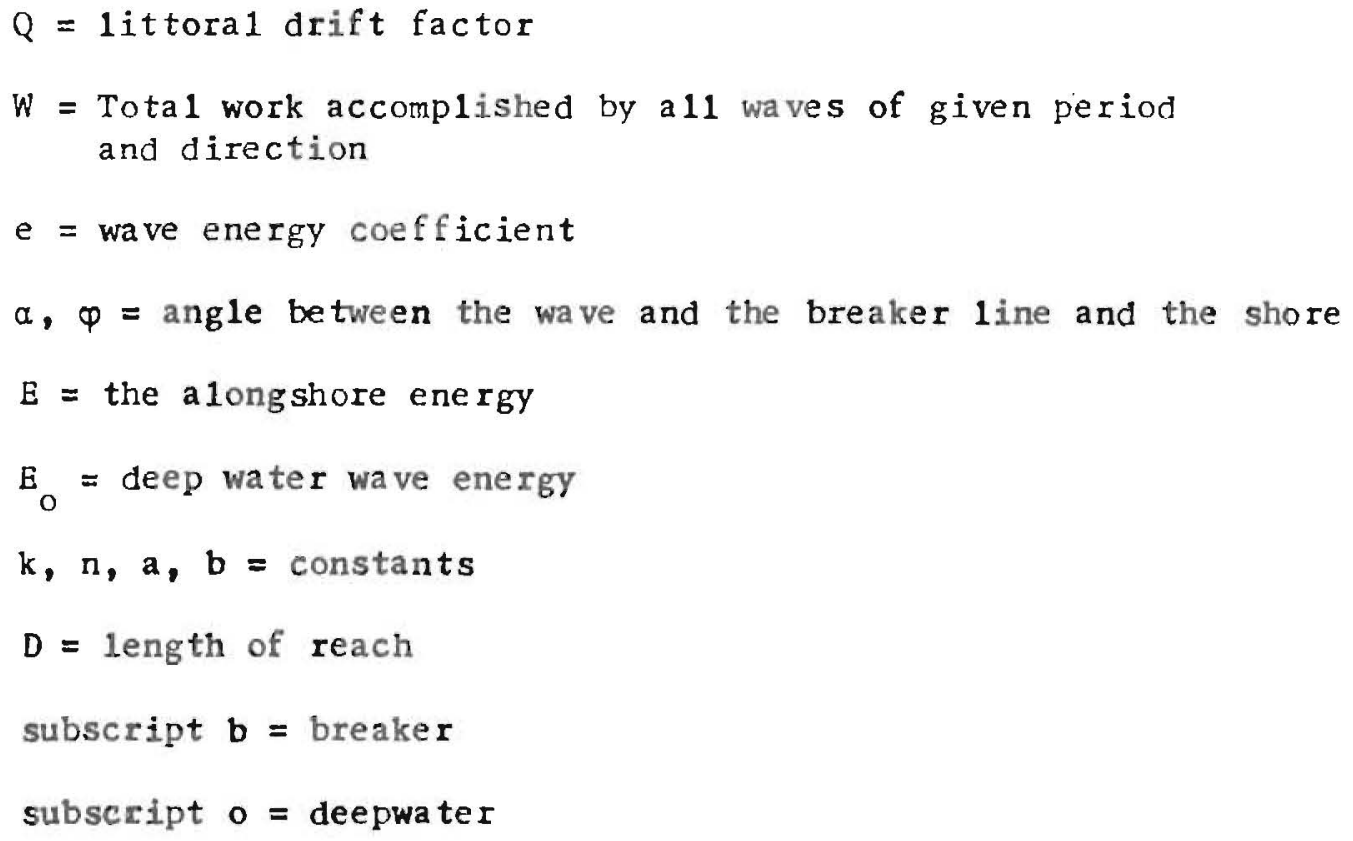

Other formulas are those by Iwagaki and Sawargi (1960), and Ishihara and Sawargi (1960).

The above authors agree that there is a relationship between the rate of littora 1 drift and the energy component paralle 1 to the shore, although energy is not a vector and a thorough discussion of these matters must necessarily involve the stress exerted on the bottom by the waves and the alongshore currents. The oscillating water motion in a wave places sediment into suspension and the littoral current furnishes a undirectional movement. Such motion meets the practical difficulty that it has not been possible to develop reliable theories for material transport in rivers and channels with unidirectional flow, although considerable advances have been made by Binstein (1950). As long as we are not able to solve this material transport problem, it is unlikely that the much more complex problem involving oscillating water motion will be solved in the near future.

\section{Rates of littoral drift by measuring deposition or e rosion:}

Another and more direct approach to the problem is the estimation of probable rates of transport along natural shorelines from the amount of material trapped by shore structures, either natural or man-made, a nd from a knowledge of sources of supply. Studies of this nature are those by Johnson, 1952; 1957; 1959). Johnson (1952) has studied the problem of accretion in the Santa Barbara harbor since the construction of the breakwater in 1929. In 1957 he gave a summary of measured rates of 1ittoral drift along coasts of the United States and presented the method of rate 
determination (whe the $r$ by scour or accretion), and in 1959 he summarized the various sources of supply and loss of sand to the coast and applied them to a reach of the coast of California. Quantitative estimates of the annual amounts of sand supplied or lost we presented.

Similar studies are those by Grant and Shepard (1936, 1937, 1939, 1946; Shepard, 1951; Handin, 1951; Pincus, 1954; Chie ruzzi, 1958).

\section{Natura 1 tracers:}

Mineral analyses of samples drawn from representative sites in a study a rea are helpful in the determination of the direction of 11 ttora 1 drift. The samples are subjected to sleve analyses and the heavy minerals from the fractions are processed microscopically by $\mathrm{X}$-ray, diffe rential the rmal analyses or by magnetic separator, and classified according to the ir geological type. Their roundness, sphericity, color and corrosion properties also are recorded. The fluvial sources of some of the se minerals can be traced and their distribution along the coast may sometimes yield important qualitative information in regard to the trends of sediment transport.

Rittenhouse (1944) determined the relative importance of various sources of sediment, which was largely sand, from the heavy mineral composition of channe 1 deposits of the Rio Grande and its tributaries. In this study, the hydraulic ratio basis of comparing mineral composition was used. This method appears to satisfy the three objections to methods in common use in rivers, namely: it uses both the frequency and absolute amounts of heavy minerals, it eliminates apparent differences in mineral composition that are associated with differences in texture of the bed deposits, and it effectively transposes the data from bed samples into usable data on mineral composition in the stream load.

Trask (1952) determined the source of sand deposited in Santa Barbara harbor by mineral grain studies. Mineralogical studies of this type generally are inconclusive, because the minerals in beach sand a re so thoroughly mixed that distinctive differences do not wholly exist. However, if part of the sand is derived from an area in which the rocks differ in mineral composition from the rocks in places from which the remainder of the sand is derived, the source of the sand is indicated by the rate of change in mineral content with respect to distance along the coast, as the original sand is progressively diluted with sand $f$ rom other a reas. Two studies of the mineral composition of the sand at Santa Barbara were made: (1) in the harbor itself in order to ascertain if the mineral content varied significantly in and near the harbor and associated beaches; and (2) along the coast we st and north of the harbor for a distance of more than 250 miles, in order to investigate migration of sand along the coast. The first study in the immediate area of Santa Barbara showed no distinctive difference in mineral content; consequently this study contributed 1ittle information of aid in understanding sand movement between the harbor and 
the beaches to the east. The second study of sand along the coast we st of santa Barbara has shown very clearly that a significant proportion of the sand at Santa Barbara comes from a distance of more than 100 miles up the coast. This conclusion wased upon the fact that the mineral, augite, a black ferromagnesian silicate found commonly in basic igneous rocks, is present in appreciable but constantly dimiaishing amounts from its source near Morro Bay southward for more than 100 miles to Santa Barbara. By a similar analysis Trask (1955) showed that sand moves around Southern California promontories.

McMaster (1960) made a study on sand movement along the Rhode Island coast. In this area beach sands are composed of a great variety of minerals, the most comon of which are amphiboles, chlorite, garnet, staurolite, and black opaques in the heavy fractions and feldspars and quartz in the light fractions. Counts of those fractions from samples collected at one-mile intervals were used as basic data for multivariate and trend analyses. The character of source materials and pattern of beach drift are believed responsible for a real differences in mineral composition. The decrease in heavy mineral percentages eastward with a general unifornity of grain size as we 11 as over-all decrease in abundance of amphiboles and feldspars and increase in garnet and black opaques seem to reflect an eastward drift away from the source area.

\section{Artificial tracers:}

\section{Use of radioactive isotopes}

Methods of sampling and mineral analyses are somewhat cumbersome in that they require a considerable amount of fleld work and laboratory research. Furthermore, bed sampling is of ten impossible under rough sea conditions and in the surf zone. These 1 imitations may be avoided by the use of radioisotopes for labeling specimens of sediment, since the se can be used in any sea state and are quite expeditiously traced with suitable detectors. A considerable literature has developed over the last five years on the detection of the movement of sediment by radioactive tracers. Many experiments have been conducted to study the feasibility of using new techniques for determining the general direction in which 1 ittoral material moves (Hours, 1955; Inose, 1955; Putman, 1956; Steers, 1957; Krone, 1957, 1959, 1960; Porest, 1957; Smith, 1957; Arlman, 1957; Redd, 1958; Ge ma in, 1958; Davidsson, 1958; Gibert, 1958; Inman, 1959; Svasek, 1961; and Ijima. 1960). A brief review of the se techniques is as follows:

Tracers. Glass, ground to the particle size distribution of the sediment under study and labeled by incorporated radioactive isotope, has been the most commonly used sediment tracer (Putman, 1956; Reid, 1958; Ge rma in, 1958; Forest, 1957; Inose, 1955; and Hours, 1955). The me thod of preparation preferred by most investigators is to incorporate an inactive isotope of the label in the glass, grind it to the desired size distribution, and activate the label by neutron irradiation just prior to placing the trace $r$ 
in the field. Boron-free soda glass is widely used. Ground glass has been used extensively for tracing sand movements. It also has been used for studying the movement of silts (Putman, 1956) and muds (Hiranandani, 1960). Natural sediment materials have been labeled with sorbed isotopes by investigators concerned with a closer simulation of sand and gravel particles (Smith, 1957), and by investigators seeking a method for labeling large quantities of sand (Gibert, 1958; Arlman, 1957). Tracers for pebbles have been made both by drilling natural or artificial pebbles and inserting an active 1abel into them (Forest, 1957; Inose, 1955; and Steers, 1956), and by sorption (Smith, 1957).

Labe1s. A number of radioactive labels have been investigated and used in tracing sediment movement. Most such 1abe1s (Sc $-46, \mathrm{Zn}_{\mathrm{n}}-65, \mathrm{Cr}_{\mathbf{r}}-51$, $\mathrm{La}-140, \mathrm{Ta}-182, \mathrm{~A}-110, \mathrm{Au}-198$, Ir - 192) emit gamma radiation which can be detected in place. For detection most of the investigators have used bundles of Geiger-Muller detectors; however, two investigators used scintillation detectors (Hours, 1955; Putman, 1956). None of the investigators used discriminators with scintillators to reject background activity. Most studies of sediment movement by tracer techniques involved sand (Putman, 1956; Reid, 1958; Germain, 1958; Forest, 1957; Inose, 1955; Hours, 1955; G1bert, 1958); ; two used pebbles (Forest, 1957; Steers, 1956); one used silt (Putman, 1956); and one used mud (Hiranandani, 1960). In a11 applications reported above measurements were made of the redistribution by wave action or tidal currents of material placed on the sea bottom.

\section{Use of luminophors:}

Luminophors have been used in many instances as a means for the detection of sediment movement (Zenkovich, 1958; Vendrov: 1957; Russe11, 1961; Halcrow, 1961). In this method natural sand particles are coated with a colloidal film of $f i n e 1 y$ disperged luminescent material which appears fluorescent when viewed in the darkness under ultra-violet 1ight. The procedure by which tracer sediment has been prepared in England (Russe11, 1961), consists of mixing the sediment samples with fluorescent dye and plastic glue and then crushing and sieving the material to the desired granular distribution.

Tracer pebbles have been prepared artificially from crushed concrete in which granulated fluorescent dye in plastic glue has been incorporated as a fine aggregate. Dyes used are Rhodamine $B$ (red); Primuline (green); Uvitex (blue); and Araldite. The variation of colors opens up possibilities of discriminating between sediment movement at various depths or at one depth as a function of grain size. Also, influences of different densities or of geometric nonsimilarities in particle shape can be studied effectively. Color differences have already been used to good advantage in tracing the velocity of progression of sand bars and in detecting the speed of advance of different fractions of sediment. Different colors of luminophors also are valuable for distinguishing test materials used at different times in the same locality, or at the same time in adjacent areas where there are 
likely to be overlapping effects. As compared with radioisotopes, luminescent tracers of fer advantages of being less costly, capable of more abundant and easier production and of being safe to handle,

\title{
PRINCIPLES OF NATURAL RADIOACTIVITY
}

\author{
Natura 1 Radioactivity
}

A11 elements found in nature with a tomic numbers greater than 83 (bismuth) are radioactive. In addition, a few of the lighter elements, namely, potassium, rubidium, samarium, leteium, rhenium, and perhaps one or two others, possess feeble radioactive properties in normal states (Glasstone, 1958). A substance or element, is radloactive when the atoms of which it is composed disintegrate spontaneously regardless of whether or not the emission of radiation can be readily detected in the process. A radio-atom in decaying may emit one or more gamma rays or it may emit none. But, no matter how many gamma-rays are enitted, such gama photons will have a characteristic wave length or energy. Abundance of gamma rays of different energy resulting from the breakdown of the two major natural radioactive decay series, i. e. uranium and thorfum, is indicated by the partial 1ist in Table 1. Only prominent ones emerge as peaks above the base spectrum.

\section{Radioactive Equilibrium}

An a tom that disintegrates to form another atom is called the parent, and the product is called the daughter. A radio-atom is in a state of secular equilibrium with its disintegration product when the same number of atoms of the daughter nuclide disintegrate as are formed in a unit of $t$ ime. Thus, in a radioactive decay series in equilibrium, the number of atoms of the nuclide being formed is exactly equal to the number of atoms of that nuclide disintegrating. The number of disintegrations per unit time, therefore, is the same for each member in the decay series. As all members of the decay series do not decay at the same rate, a greater amount of the long-1ife nuclides will have to be present to provide the same number of disintegrations per unit time as those coming from the short-life nuclides; consequent1y, the amount of nuclide present in a decay series in equilibrium is directly proportional to its half-life,

$$
\lambda_{1} N_{1}=\lambda_{2} N_{2}=\lambda_{3} N_{3}=\ldots \ldots \ldots . . . . .=\text { constant }
$$

where $\mathbf{N}$ is the number of atoms of the daughter present and $\lambda$ is its decay constant. A state of non-equilibrium exists when all or part of one or more of the daughters or parents is physically removed from the decay series. If a nuclide with a short half-life is removed, equilibrium can be rapidly regained. If a nuclide with a long half-life is removed, it may be millions of years before complete equilibrium is regained be tween all members of the decay chain. 
TABLB 1

PRINCIPAL GAMMA RAYS IN URANIUM AND THORTUM SERIES*

\begin{tabular}{|c|c|c|c|}
\hline $\mathrm{z}$ & I sotope & A & Bnergy in Mev of gamma rays \\
\hline & & & URANIUM 238 SBRIES \\
\hline 92 & Uranium & 238 & 0.05 Coincident with 22 percent of alpha rays \\
\hline 90 & Thoriun & 234 & 0.09320 percent of disintegrations \\
\hline 91 & Protactinium & 234 & 0.82 Weak \\
\hline 92 & Uranium & 234 & $\gamma_{1} 0.053, \gamma_{2} 0.093, \gamma_{3} 0.0118 \quad \gamma_{1} / \gamma_{2} / \gamma_{3}=1 / 0.2 / 0.4$ \\
\hline 900 & Thorium & 230 & $0.068,(-.14,0.24)$ \\
\hline 88 & Radium & 226 & 0.188 \\
\hline 86 & Bmanation & 222 & \\
\hline 82 & Polonium & 218 & \\
\hline 82 & Lead & 214 & $\gamma_{1} 0.053, \gamma_{2} 0.242, \gamma_{3} 0.257, \gamma_{4} 0.295, \gamma_{5} 0.352$ \\
\hline 83 & Bismuth & 214 & $\begin{array}{l}\gamma_{1} 0.609, \gamma_{2} 0.766, \gamma_{3} 0.933, \gamma_{4} 1.120, \gamma_{5} 1.238, \\
\gamma_{6} 1.379, \gamma_{7} 1.520, \gamma_{8} 1.761, \gamma_{9} 1.820 \\
\gamma_{11} 2.420\end{array}$ \\
\hline 84 & Polonium & 214 & \\
\hline 82 & Lead & 210 & 0.0467 \\
\hline 83 & Bismuth & 210 & No. $Y$ \\
\hline 84 & Polonium & 210 & 0.80 \\
\hline
\end{tabular}

THORIUM 232 SERIES

90 Thorium 232

$0.055(0.075)$ Councident with 24 percent of a1pha rays

88 Radium 228

0.03

89 Actinium 228

90 Thorium 228

88 Radium 224

86 Emanation 220

84 Polonium 216

82 Lead 212

83 Bismuth 212

$0.058,0.129,0.184,0.338,0.462,0.914,0.969$

0.0843

0.241

$\gamma_{1} 0.115, Y_{2} 0.176, \gamma_{3} 0.238, \gamma_{4} 0.249, Y_{5} 0.299$

with $\alpha .040(\sim 4 \%), 0.144,0.164,0.288,0.328$, $0.4-2.0 .452,0.472$ with $B=2.20,1.81(\sim 7 \%)$,

84 Polonium 212

81 Thallium 208 (Equilibrium disintegration of T1208 on $1 \mathrm{y} 35 \%$ of other elements in series owing to branching of $\left.\mathrm{Bi}^{212}\right) .2 .62(\sim 00 \%, \mathrm{e} / \mathrm{\gamma} \sim 0.002) ; 0.510$

$(\sim 25 \%, e / \gamma \sim 0.08) ; 0.277\left(10 \%, e / \sim_{0} .3\right)$

‡ From Hollander, Perlman, and Seaborg (1953). 
Por a natural rock practically all the gamma radiation comes from three sources, namely, $K 40, U^{238}$ series, and $T^{232}$ series (Adams et al, 1958). Figures 2,3 and 4 show gamma scintillation spectra for potassium uranium, and thorium, respectively. Uranium is generally found with thorium in nature in a ratio of about 10 parts of thorium to one part of uranium. The gamma rays from $U^{238}$ and $T^{232}$ themselves are of such a 1 ow energy value as to make direct measurements impractical. Where secular radioactive equilibrium prevails, the abundance of $U^{238}$ or $T^{232}$ can be determined by measuring the activity of any daughter in the respective series. This follows from the constant ratios that exist between the concentrations of the various members of a series in an equilibrated sample.

Techniques of this type, capable of measuring a few parts per milition of thorium and uranium present in common rocks, have been developed by Hurley (1956) and by Adams, et a1 (1958). The main difference between the two ganma-ray techniques involves the choice of spectral energies. Hurley used three channels centered at the following energies: 0.18 and $0.238 \mathrm{Mev}$. for uranium and thorium, and $1.46 \mathrm{Mev}$. for potassium. With this cholce of energies the potassium interference at 0.18 and $0.238 \mathrm{Mev}$. could be neglected only for samples containing more than $100 \mathrm{ppm}$, of equivalent uranium in equilibrium with its daughters. For Adams' work higher energy gamma rays were chosen: $1.86 \mathrm{Mev}$. from $\mathrm{Bi}^{214}$ in the uranium series and 2.63 for $\mathrm{Tl}^{208}$ in the thorium series. With the energies potassium can be ignored even when present in higher concentrations, because its spectrum contributes no appreciable gamma ray pulse above $1.6 \mathrm{Mev}$. Thus it is possible to determine the abundance of uranium from only two spectral measurements. Although this scheme has the advantage of less interference from higher energy gamma rays, it has the disadvantage of a lower counting rate. In the present work, the sand samples analyzed had very low activity; consequently the energy levels used by Adams were undesirable.

In California rocks potassium is found in the following forms (Pabst, 1938): Arcanite, Hanksite, Potash Alum, Vollaite, Krausite, Metavoltine, Alunite, Jarosite, Arthocla se, Microcline, Phillipsite, Celandorite, Apophylilte, Muscovite, Roscelite, Biotite, Phlogopite, Lepidolite, Glauconite, and Neptunite. Of the se the following have a specific gravity higher than bromoform $\left(2.87\right.$ at $\left.20^{\circ} \mathrm{C}\right)$; Jarosite (3.15-3.26), Neptunite $(3.19-3.23)$; Biotite $(2.67-3.16)$, and Muscovite $(2.76-3.0)$. Rnowing that uranium is found in the form of Monazite (9.15), which is strongly radioactive, and that thorium is in the form of Thorite $(5.2-5.4)$, it is obvious that the Monazite and Thorite particles will settle much faster than 


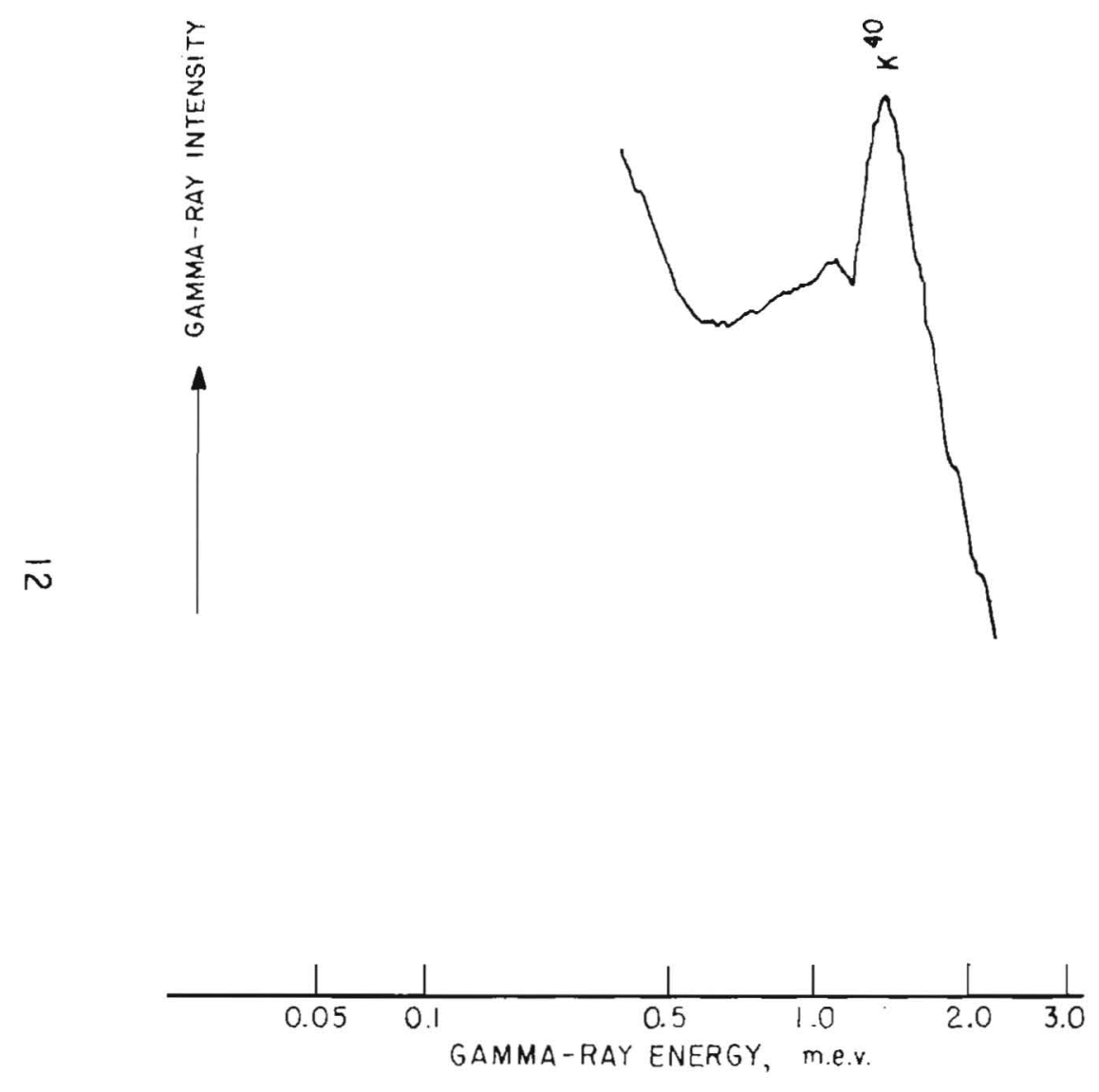

FIG. 2 GAMMA-RAY SPECTRUM FOR $\mathrm{K}_{2} \mathrm{CO}_{3}$

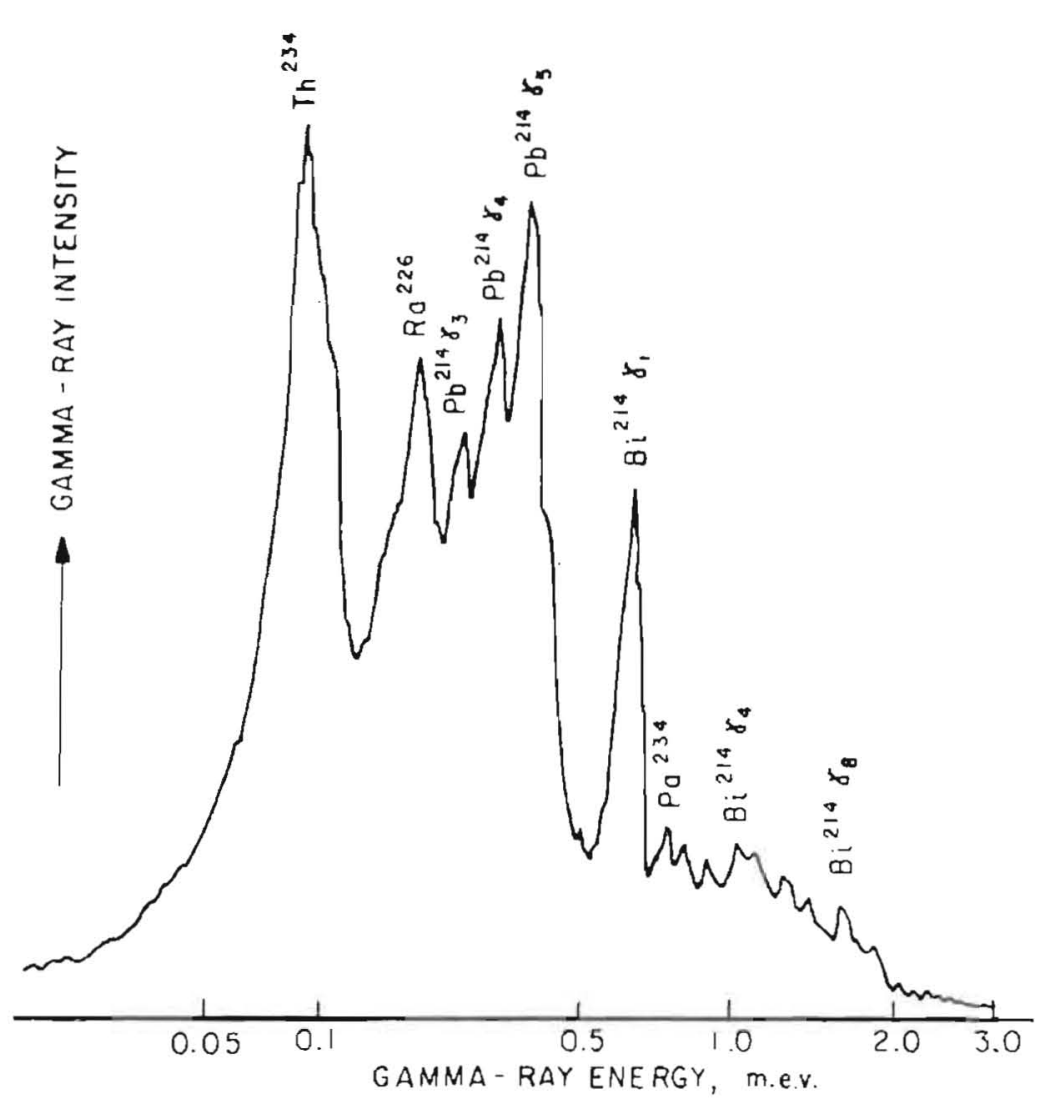

FIG 3 GAMMA - RAY SPECTRUM FOR UO 


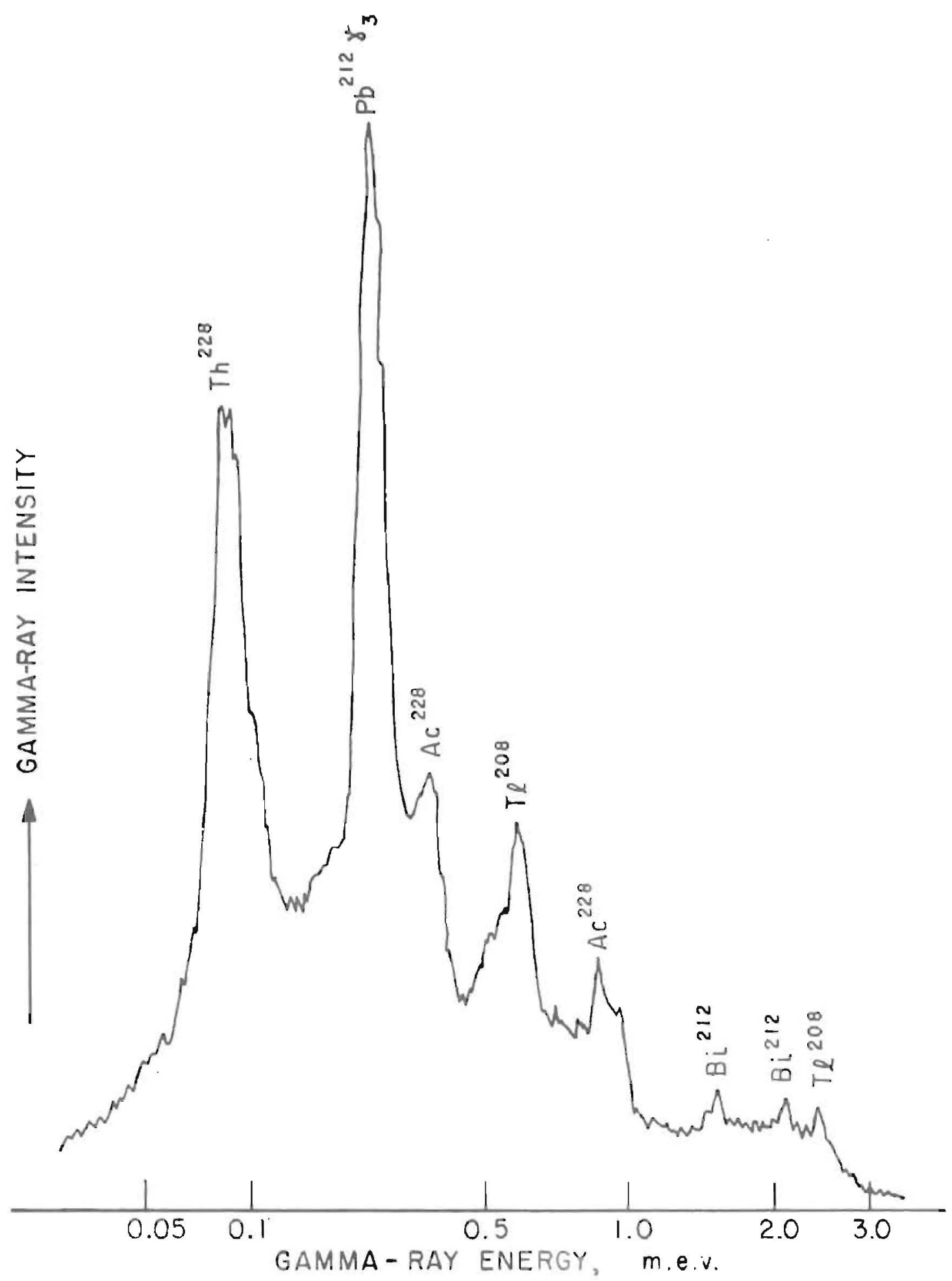

FIG. 4 GAMMA-RAY SPECTRUM OF ThO

13 
Potassium in any of its forms. Consequent1y, if we do not wait until the Potassium particles settle down, * the heavy minerals separated will not contain potassium.

In the present work bromoform $\left(2.87\right.$ at $\left.20^{\circ} \mathrm{C}\right)$ was used for the following reasons to separate the heavy minerals including thorite, monazite, and zircon from the sand samples:

1. Decrease source absorption effect.

2. Elimination of the potassium minerals present in the sand samples since most of the potassium minerals have a specific gravity less than that of Bromoform (2.87 at $20^{\circ} \mathrm{C}$ ). The gamma spectrum of the potassium free heavy minerals will not have a $1.46 \mathrm{Mev}$. peak from $\mathrm{K}^{40}$ in the potassium series which interferes with the $0.188 \mathrm{Mev}$. and $0.238 \mathrm{Mev}$. peaks in the $\mathrm{U}^{238}$ and $\mathrm{Th}^{2} 232$ series respective $1 \mathrm{y}$. This elimination of the $1.46 \mathrm{Mev}$. $\mathrm{K} 40$ peak will enable us to use the 0.188 and $0.238 \mathrm{Mev}$. energy leve $1 \mathrm{~s}$ for counting the abundance of $\mathrm{U}^{238}$ and $\mathrm{Th}^{232}$ respectively present in the heavy minerals. The se energy levels, i.e. 0.188 and $0.238 \mathrm{Mev}$. have the advantage of giving a high counting rate which is necessary in the analysis of samples of such low activity.

Pigure 5a shows the spectra of a sand sample before separating its heavy minerals with bromoform, and Figure $5 \mathrm{~b}$ shows the spectra of the heavy minerals of a sand sample separated by bromoform. (Notice the disappearance of the $1.46 \mathrm{Mev}$. peak from $\mathrm{K}^{40}$ in the potassium.)

3. The concentration of thorium (in parts per million) in a 1 imited size fraction of the heavy minerals of the sand samples and the concentration of heavy minerals (in percent) in the same size fraction of the sand samples are to be used as parameters for determining the direction of 1ittoral sand drift along the coast as explained in the next chapter.

* Exact calculation of the time required for each particle to settle by using Stokes' equation or Rubey's impact equation is impossible since the assumptions used in both equations a re not completely satisfied in this case. A rough estimate of the settling time was made which gave the following ratios between the settling time of Monazite, Thorite, and Potassium -1:2,5:16. However, we cannot depend on the se ratios and the use of another liquid of higher sp. gr. than 3.26 (Methylene Iodide, 3.32 at $20^{\circ} \mathrm{C}$ ) is recommended if potassium is known to be present in the sand samples. 

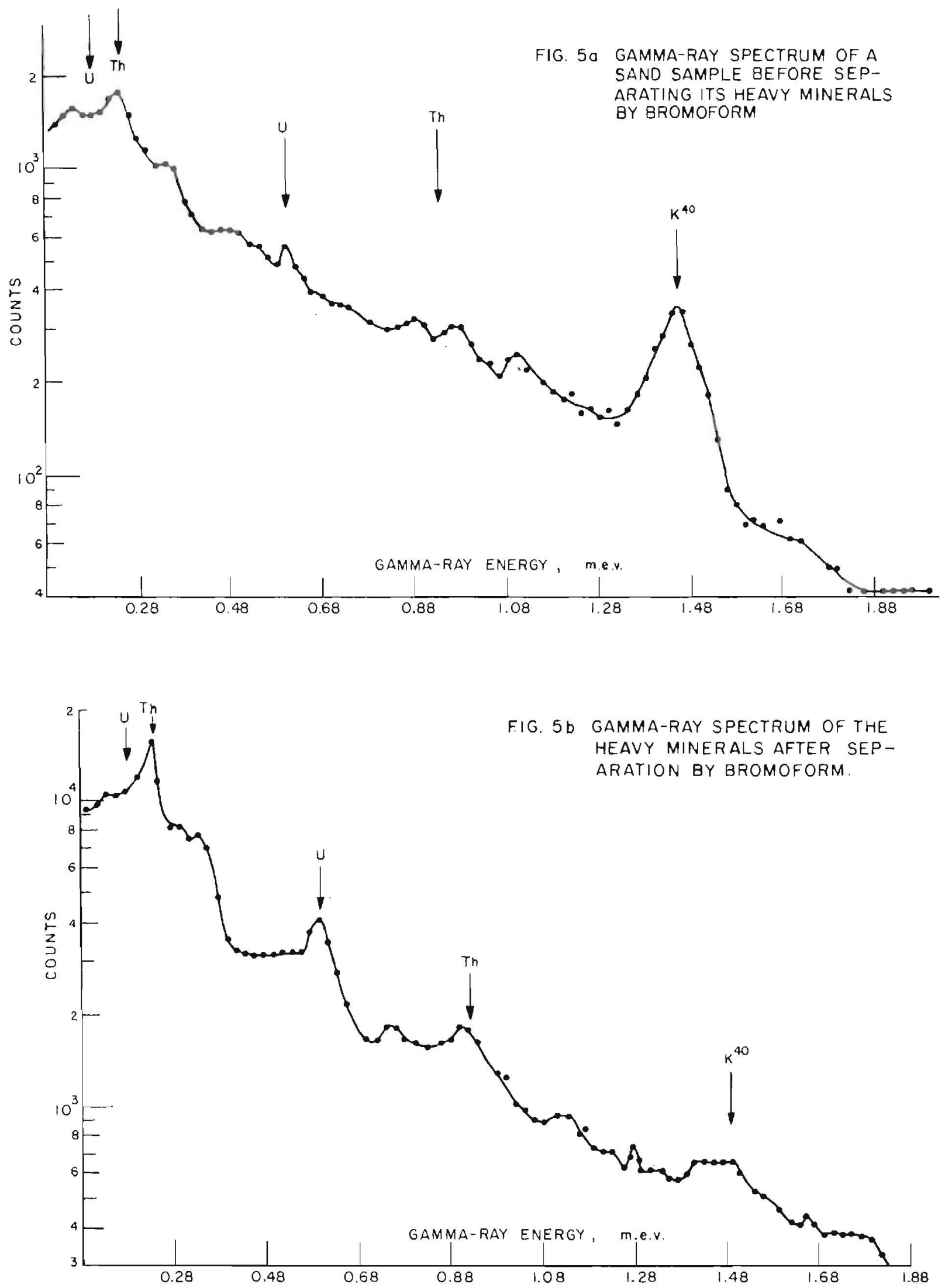


\section{INVESTIGATIONAL PROCEDURES}

\section{Genera1 Approach}

It is we11 know that beach sands are among the best sorted of natural. sediments. They are subject to a progressive sorting when transported by alongshore currents and to a very effective local sorting by the oscillatory motion of the waves. The contention that sediment transported by alongshore currents trave1s chiefly in suspension is supported by the textural characteristics of the beach sands. Silt and clay are absent; very fine sand is rare. Any effects of progressive sorting along the shore must, therefore, be explained on the basis of transportation in suspension. These effects may be due to sorting according to grain shape, size, and specific gravity. Progressive sorting according to size, shape, and specific gravity may be due to a progressive decrease in the competency of the transporting agent or to fluctuations in the competency with a lagging behind of the 1arger, spherical, and heavier particles which move only occasionally during periods of maximum competency. The competency of the alongshore current would seem to depend on the ability of the waves to put sediment of a certain grain size in suspension, and then or the ability of the current to move the suspended load. In the present study the choice of the concentrations of both thorium and heavy minerals in parts per million and percent, respectively, in sand samples collected at mid-tide from different places along the beach, are believed to be two good parameters for the study of the effect of progressive sorting and consequently the determination of the direction of littoral drift along the coast.

A decrease from a source area in the concentration of thorium in ppm. and/or the concentration of the heavy minerals in percent should indicate alongshore drift in the direction of decreases of both parameters.

Local sorting on the other hand, need not be a result of transport in suspension, and its effects must not be confused with those of progressive sorting. To eliminate the effect of local sorting on the sand samples, comparisons between the concentrations of thorium and heavy minerals present in the se samples should be made only for a very limited size fraction and not for the whole sample, e.g., a size fraction from 74 to 177 microns.

Since thorite is general1y found in the size fraction finer than 125 microns (Hutton, 1951), and since the concentration of heavy minerals is also higher in the fine fraction, it was found that the best size fraction suited for this study is that from 74 to 177 microns. For samples where there is not enough fine materials, comparison was made for the size fraction from 125 to 250 microns.

Me thod of taking sand samples

A series of samples of beach and river sands were collected along the California Coast between north of the Russian River and Point San Pedro, a 
distance of more than 90 miles. The surface sand samples were taken by scraping the surface with a straight edge, drawn parallel to the shore and penetrating only a few millimeters in depth. Such a sample can be of the required volume, yet come from a grain-size population which is similar in a11 its areal parts, representing a unique hydraulic condition of deposition. Since littoral sand transport may change direction with time, and since the desired object is to define the direction of sand movement, it is clear that sand samples must be collected which represent only one general direction, that is, all samples for comparison must be of sand moving during one short time interval. For this reason all samples were taken at mid-tide within a period of three days.

Some deep samples also were collected at the same time and from the same location as the surface samples. These deep samples were taken at a depth of one foot by digging a hole of abbut one square foot area and one foot deep.

\section{Instrumentation}

The spectra of uranium and thorium series (Figure 6) show that the peak caused by lead 212 in the thorium series occurred in a region of faitly constant response in the uranium series and might best fulfill the needs for discrimination of the two series. Furthermore, higher counting rates at this low-energy part of the spectrum make it desirable to work in this part of the spectrum. In a radioassay with gamma rays of this low energy leve1, the thickness of the source must be small so that the photopeaks are not swamped by compton-scattered radiation from within the source, otherwise a correction should be made as discussed in Appendix III.

\section{Background determination}

The analysis of the radioactivity of the sand samples was done in a room that is not radioactively contaminated. The background counting in this room was very constant which is the required case for effective radiometric work when the assayed samples are weakly radioactive. Since the gamma rays concerned are from natural sources of low activity, it is necessary:

1. To maximize the total count-to-background ratio, for this reason a counting time of three hours on the average was used.

2. To minimize instrumental drifts - which a re critical in attempts to stay close to the top of the peak. This difficulty was overcome by running standards at frequent intervals.

The average background during the analysis was found to be equal to $4.308 \mathrm{cpm}$. at $0.188 \mathrm{Mev}$. and $4.888 \mathrm{cpm}$ at $0.238 \mathrm{Mev}$. For a counting period 


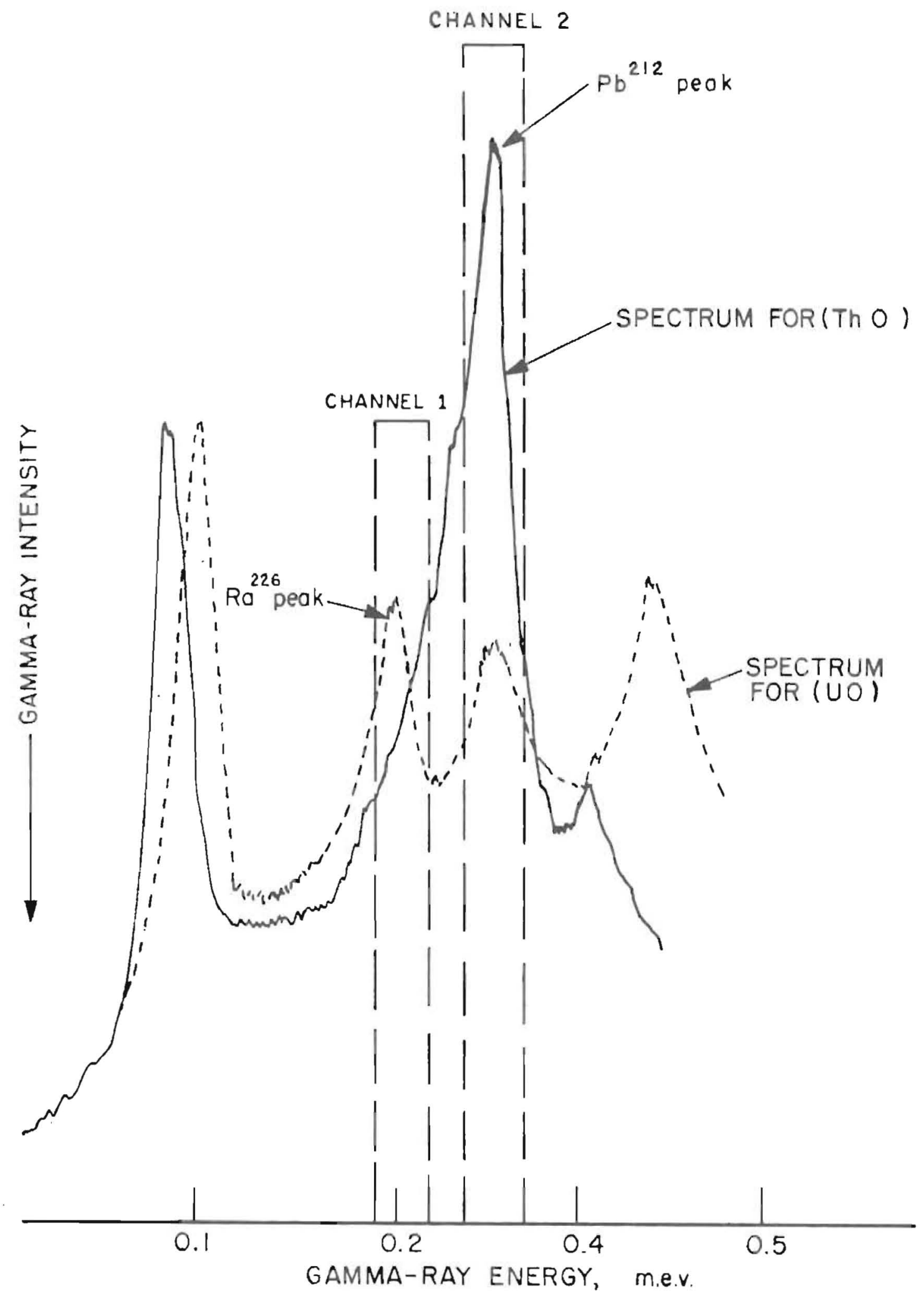

FIG. 6 COUNTING CHANNELS FOR THORIUM AND URANIUM 
of 200 minutes on the average, the minimum detectable counting rate $\left(M_{0} D_{0} C_{0}\right)=2 \sqrt{\frac{2 n b}{2}}$, where $n b$ is the background count in $\mathrm{cpm}$. For
the present study

$$
\begin{aligned}
& \text { M. D.C. at } 0.188 \mathrm{Mev}=0.417 \mathrm{cpm} \text {. }
\end{aligned}
$$

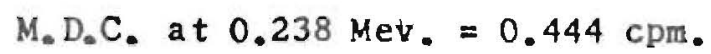

Method of analysis and tests

The samples were washed with fresh water to remove sea-sa1t, dried, and then analyzed mechanically with sieves by the customary procedure of using a rotary shaker and a period of shaking of 30 minutes. The size fraction 74 to 177 microns (for some samples size fraction 125 to 250 was also separated) was placed in bromof orm, (specific gravity 2.87 at $20^{\circ} \mathrm{C}$ ) for the separation of the heavy minerals (Krumbein and Pettijohn, 1938). The heavy minerals so separated we re weighed and placed in a plastic container which was then placed in the top of the detector for counting.

The radiation from the radioactive minerals present in the sample was determined by counting at two bands centered at $0.238 \mathrm{Mev}$. and $0.188 \mathrm{Mev}$. for thorium and uranium, respectively, for a perlod of about three hours. Each analysis included one or more callbration with a standard. The drift error depends on the time interval between the calibrations. The counting error is the square root of the total count.

The operating procedure was as follows: A standard thorium source ( $\left.4100 \mathrm{C}_{0} \mathrm{P}_{0} \mathrm{M}_{2}\right)$ was used to correct for variations in the counting response. After several measurements of this standard, a mean value for each channel. was found, and some arbitrary value close to the mean value was chosen to represent a datum for the channe1. Henceforth, all readings were corrected with reference to this datum. Thus, if the standard source was run before and after an unknown and showed that channe 12 is counting 5 percent below the datum level, the reading for the unknown was corrected upward by 5 percent to make it homogeneous with the fixed calibration constants, which were also based on the datum values.

At the start of a batch of samples the two channels were centered on the valley and the peak, respectively, by using a thorium-rich source and varying the base-line discriminator a sma11 amount each way. A standard uranium sotirce was then run, preceded and followed by the standard thorium source, which was always used to correct the measured values for instrument drift (See Appendix II for adjusting the gamma-ray spectrometer). After this, the unknowns were run alternately with the thorium standard.

The calculation of the quantities of thorium and uranium in an unknown was a follows: "Counting rate" means net counting rate af ter background 
has been removed and corrected for drift by calibration with the thorium standard.

$T=$ weight of thorium in thorium standard in micrograms. $T_{1}=\begin{aligned} & \text { counting rate from thorium standard in channe } 11 \text { in counts } \\ & \text { per minute. }\end{aligned}$

$\mathrm{T}_{2}=$ counting rate from thorium standard in channe 12 in counts per minute.

$U=$ weight of uranium in uranium standard in micrograms.

$\mathrm{U}_{1}=$ counting rate $\mathrm{f}$ rom uranium standard in channe 11 in counts per minute.

$\mathrm{U}_{2}=$ counting rate from uranium standard in channe 12 in counts per minute.

$R_{1}=$ counting rate from unknown sample in channe 11 in counts per minute.

$R_{2}=$ counting rate from unknown sample in channe 12 in counts per minute.

In the value found for $R_{2}$ if $X, Y$ a re the counts per minute due to uranium and thorium, respectively, the solution of the following equations will give the required results:

$$
\begin{aligned}
& \left(U_{1} / U_{2}\right) X+\left(T_{1} / T_{2}\right) Y=R_{1} \\
& X+Y=R_{2} \\
& \frac{\mathrm{X}}{\left|\begin{array}{cc}
1 & -\mathrm{R}_{2} \\
\left(\mathrm{~T}_{1} / \mathrm{T}_{2}\right) & -\mathrm{R}_{1}
\end{array}\right|}=\frac{\mathrm{Y}}{\left|\begin{array}{cc}
-\mathrm{R}_{2} & 1 \\
-\mathrm{R}_{1} & \left(\mathrm{U}_{1} / \mathrm{U}_{2}\right)
\end{array}\right|}=\frac{1}{\left|\begin{array}{cc}
1 \\
\left(\mathrm{U}_{1} / \mathrm{U}_{2}\right) & \left(\mathrm{T}_{1} / \mathrm{T}_{2}\right)
\end{array}\right|} \\
& X=\frac{R_{1}-\left(T_{1} / T_{2}\right) R_{2}}{\left(U_{1} / U_{2}\right)-\left(T_{1} / T_{2}\right)} \quad \text { counts per minute } \\
& Y=\frac{-R_{1}+\left(U_{1} / U_{2}\right) R_{2}}{\left(U_{1} / U_{2}\right)-\left(T_{1} / T_{2}\right)} \quad \text { counts per minute } \\
& \left(U_{1} / U_{2}\right)=2.832 \\
& \left(U_{1} / U_{2}\right)-\left(T_{1} / T_{2}\right)=2.446
\end{aligned}
$$

When 10 or more grams of heavy minerals we re assayed, correction for sample size was made as indicated in Appendix III. 
Samples were obtained at a number of localities to investigate the following problems:

A. To study the direction of 1 ittoral drift along a reach of the California Coast.

1. Sample Nos, 1 to 59 (Table 1, App. IV) were surface and deep samples collected at mid-tide during the period between June 15 and June 18, 1961. (Pig. 7)

2. Sample Nos. 60 to 69 (Table 2, App. IV) we re bottom samples collected from the Pacific Ocean in the vicinity of the San Prancisco Bar. (Fig. 11)

B. To study the variation in thorium concentration along a beach profile.

1. Samples from a to $h$ (Table 3 , App. IV) we re surface samples taken along a profile at location 30 at Drakes Bay on June 6, 1961. (Fig. 13)

C. To study the variation in thorium concentration with time at a specific location on a beach.

1. Samples from a to d (Table 4, App. IV) we re surface and deep samples taken at mid-tide at location No, 48 at different times. (Fig. 14)

In this study the three factors considered in determining the direction of littoral drift along the part of the California Coast from the Russian River to Point San Pedro are as follows:

1. The concentration of thorium (in parts per million) in the heavy minerals of a limited size fraction of the sand sample analyzed.

2. The percent of heavy anerals in the same size fraction used in (1).

3. Have refraction diagrams.

The first factor, 1. e., concentration of thorium in ppm., will represent the effect of progressive sorting caused by the littoral current on the beach sands. This will result in a dilution of the amount of thorium present in the sample in the direction of littoral drift. This will be noticed as a decrease in the concentration of thorium with distance from the source area, in the direction of littoral drift. The second factor, i. e., the concentration of heavy minerals in percent, will also represent the 
effect of progressive sorting by the littoral current. Since once in suspension, heavy mineral particles have the tendency to settle faster than lighter particles, the result will be a decrease in the concentration of heavy minerals in the direction of littoral drift. The third factor, i.e.. wave refraction patterns, gives a good indication of the direction of sand drifting along a coast since it is agreed that the littoral drift is caused by the energy component of waves breaking at an angle to the shore. Some geological observations will also be considered, wherever possible, to help in deternining the direction of 1ittoral drif $t$.

In the samples analyzed for both thorium and heavy minerals, it was found that both surface and deep samples (one foot deep) have the same trend (Pig. 7). The beaches under study are variable beaches (Trask, 1958). They vary not only from one season to anothe $r$, but also from place to place on any given beach at any given time. The chief seasonal variations in individual beaches are in grain size, sorting, height of berm, and position and shape of the foreshore. Some of the beaches always have cusps, others never, and some have cusps sometimes and not at other times. Though no consistent pattern is indicated for all beaches, most of the beaches build up in width during sumer and e rode during winter. Howeve $r$, as wave height varies from one day to another, the beaches may build or erode at any time. From the above discussion on variability of beaches, the sand samples analyzed will be considered to represent conditions during which they we re collected, i.e., sumer conditions. Consequently the samples analyzed will indicate the direction of littoral drift during the sumer. This may agree with the predominant direction of drift for some localities and may not agree for others.

The predominant direction of drift along the part of the coast under study is generally considered to be from north to south. This is based on analyses of wave refraction diagrams (Fig. 15) drawn for the predominant waves in this area which come from $W . N . W$. with a wave period of 12 seconds (Nationa1 Marine Consultants, 1960). Actua11y such ref raction diagrams represent both the predominant and summer conditions, since wave conditions for both are very similar (National Marine Consultants, 1960).

\section{A. TO STUDY THE DIRBCTION OF LITTORAL DRIFT ALONG A REACH OF THE CALIFORNIA COAST}

1. From north of the Russian River mouth to Bodega Head (Fig. 8)

This reach includes the beach from Russian Gulch to the Russian River mouth (samples 1 to 5). The Russian River (samples 8 to 11), Bodega Head south of the Russian River mouth (samples 6 and 7), She 11 Beach (sample 12), Wright Beach, Gleason Beach, Arched Rock Beach, and Salmon Creek Beach (samples $13,14,15,16$, re spectively). 


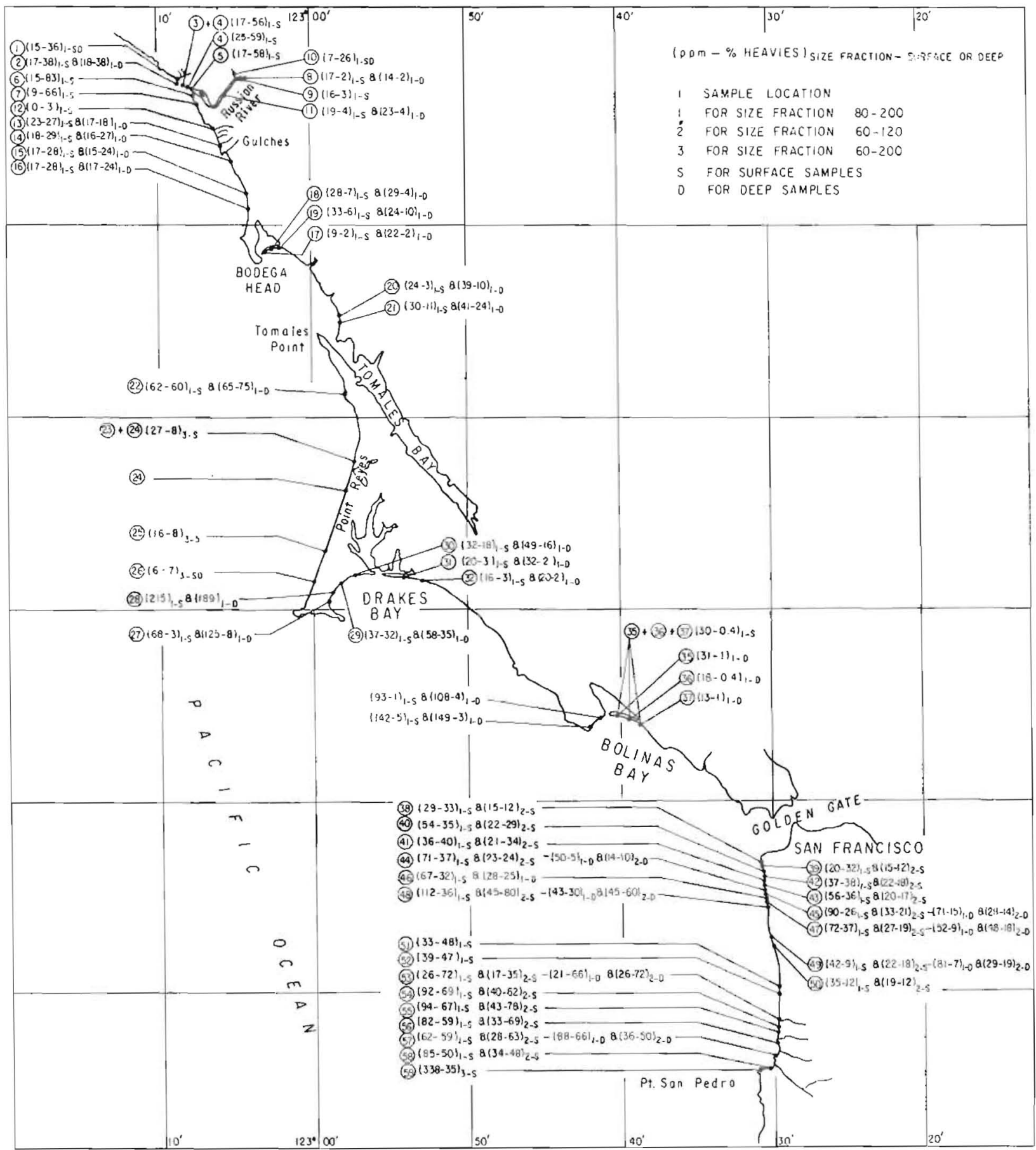

FIG. 7 NUMBER AND LOCATION OF SAMPLES, THEIR THORIUM AND HEAVY HYO- $-87 / 4$

MINERALS CONCENTRATION 


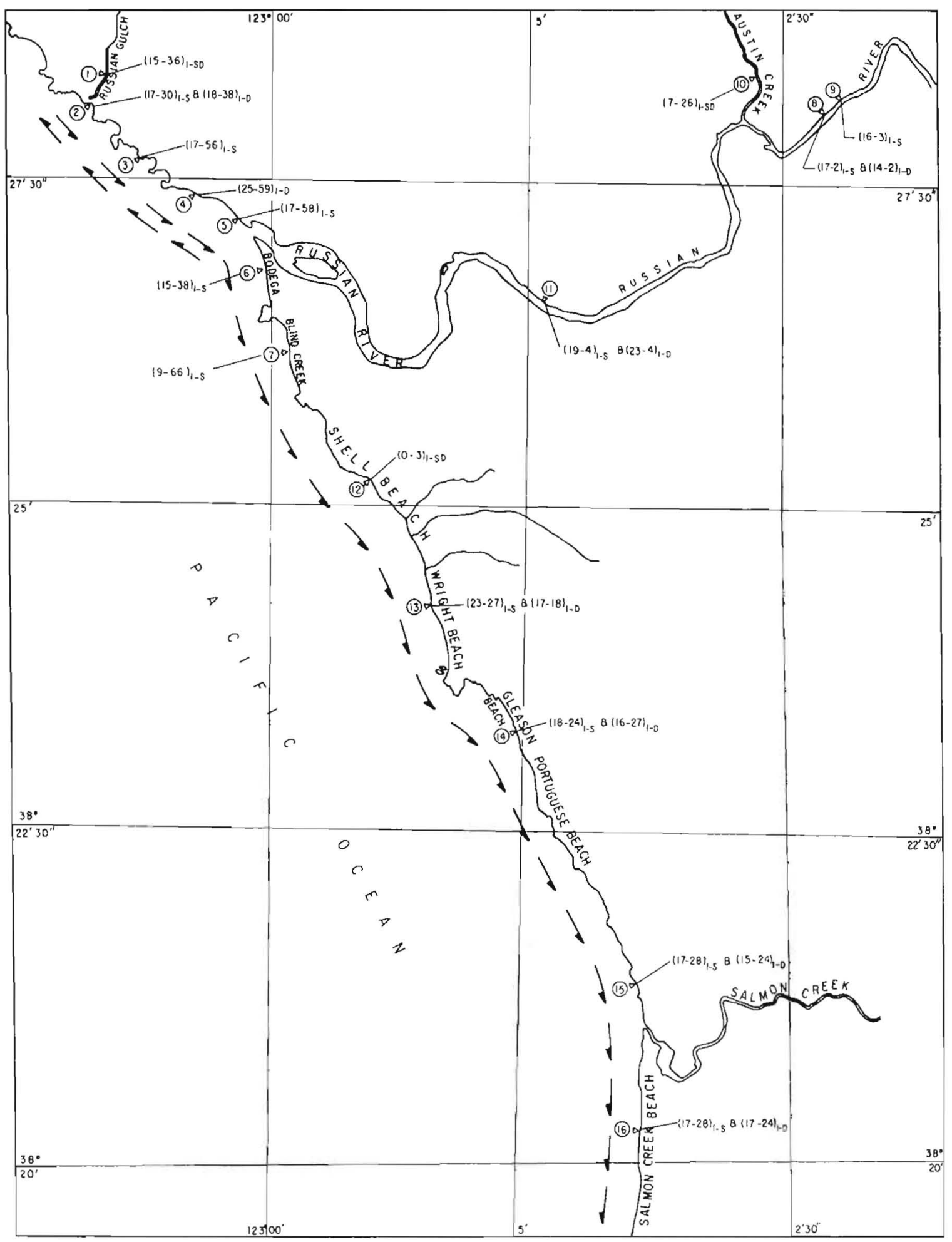

FIG. 8 NUMBER AND LOCATION OF SAMPLES FROM NORTH AT THE RUSSIAN RIVER MOUTH TO BODEGA HEAD, THEIR THORIUM AND HEAVY CONCENTRATIONS, AND HYO.87T5 THE DIRECTION OF LITTORAL DRIFT, 
For the part of the cosst north of the Russian River mouth; though the refraction diagrams indicate a southward drift, the concentrations of both thorium and heavies did not show any consistent significant decrease. The concentration of thorium and heavy minerals varied along the coast from 15 to $25 \mathrm{ppm}$. and from 56 to 59 percent, respectively, without any consistent trend. The littoral drift in this part of the coast is believed to have a reversal in direction.

The Russian River samples showed a thorium concentration of 14 to 17 ppm. upstream from the junction with Austin Creek which has a concentration of $7 \mathrm{ppm}$. and $19 \mathrm{ppm}$. downstream from Austin Creek (Fig. 8). Thorium found on the beaches just north and south of the Russian River mouth probably is brought to the coast by the Russian River as it flows through thorium-rich granite rocks.

South of the Russian River mouth the concentration of thorium and heavy minerals decreases gradually and consistentiy from $15 \mathrm{ppm}$. and 83 percent for sample 6 , to zero ppm. and 3 percent for sample 12 at She 11 Beach (Fig. 8). This indicates a southward direction of lit toral drif $t$ and confirms the conclusion from the analysis of the wave refraction diagrams.

For the part of the coast from Wright Beach south to Salmon Creek Beach, the concentration of thorium increased suddenly from zero at She 11 Beach to $23 \mathrm{ppm}$. at Wright Beach. This is believed to be due to the sediments brought to the coast by some sma11 streams which enter the coast be tween She11 Beach and Wright Beach (samples 12 and 13, respective1y) and which pass through thorium-rich granite rocks. The $23 \mathrm{ppm}$. thorium concentration for sample 13 at Wright Beach decreases gradual1y to $17 \mathrm{ppm}$. (sample 16) at Salmon Creek Beach. Although the concentration of hea vy minerals does not have significant differences, both the thorium concentration and wave ref raction diagram suggest a southward direction of drift for this part of the coast.

\section{Prom Bodega Head to Tomales Point (Fig. 9)}

Bodega Head and Tomales Point are a continuation of the same geologic formation. The direction of sand drift in Bodega Bay depends on the 1oca 1 conditions. The samples collected and analyzed for Bodega Bay (samples 17 to 21) showed a general decreasing trend in both the concentration of thorium and heavy minerals in a northwestward direction. The concentration of thorium decreased from $30 \mathrm{ppm}$. for sample 21 to $9 \mathrm{ppm}$. for sample 17 ; a 1 so the percent heavy minerals decreased gradually from 11 to 2 percent for the same two samples. This suggests a northwestward direction of littoral drift during the period when the samples we re collected (summer season). However, the great preponderance of chert and greenstone among the pebbles on Point Reyes Beach indicates that most of the beach ma te rial comes $f$ rom the mainland east of the Point Reyes Peninsula, because no rocks of this characte $r$ 
are found on the Peninsula. This means that the se pebbles in some way have been transported across the mouth of Tomales Bay in water 5 to 10 feet deep (Trask, 1958). Wave refraction diagrams also indicate a southward direction of drift. In conclusion it is believed that littoral sand movement in Bodega Bay is subject to reversals in direction.

\section{Point Reyes Beach (Fig. 10)}

Point Reyes Beach is a long straight beach. The refraction diagram drawn for W.N.W. waves with a period of 12 seconds (Pig. 15) shows that the direction of wave approach is parallel to the shore. However, waves approaching the shore from the north or south of the W.N.W. direction will result in a southward or northward littoral drift, respectively.

Samples analyzed for the Point Reyes area include sample 22 at MoClures Beach and samples 23 to 26 at Point Reyes Beach. The concentration of thorium for McClures Beach is $62 \mathrm{ppm}$. This relatively high concentration is attributed to the thorium-rich granite rocks which outcrop at the seacoast in this area. The thorium concentration decreases gradually southward from $62 \mathrm{ppm}$. for sample 22 to $6 \mathrm{ppm}$. for sample 26 (Pig. 10). The concentration of heavy minerals also shows a southward decrease from 60 to 7 percent. This southward decrease in both thorium and heavy minerals concentrations suggest a southward direction of littoral drift. However, the presence of a few rounded pebbles of acid porphyry suggests the migration of material from Point Reyes (Trask, 1958).

In conclusion, it is believed that sand movement along Point Reyes beach is subject to reversals in direction. This confirms the conclusion derived from a study of the wave refraction diagrams for this beach, since waves approaching from the north will result in a southward littoral.drift while waves approaching from the south will result in a northward drift.

\section{Drakes Bay (Fig. 10)}

Except for sample 27 at the southwest end of Drakes Bay, a significant gradual eastward decrease occurs in both the concentrations of thorium and heavy minerals (Fig. 10). The thorium concentration decreases from $215 \mathrm{ppm}$. for sample 28 to $16 \mathrm{ppm}$, for sample 32 . The heavy minerals concentration decreases from 43 to 2 percent for the same samples. The source of high concentration of thorium in this area is believed to be the thorium-rich granite rocks which outcrop at the seacoast near location 28 . This thorium is then diluted as it moves eastward. The decrease in both thorium and heavy mineral concentrations to the east and the wave refraction diagram pattern a11 suggest an eastward direction of 1ittoral drift in Drakes Bay. The southwestward decrease in both thorium and heavy mineral concentrations for sample 28 to 27 (Pig, 10) is explained as follows: When a source of material enters the shore at a point, wave action will tend to dilute this material on both sides of the point source. It has also been observed in 


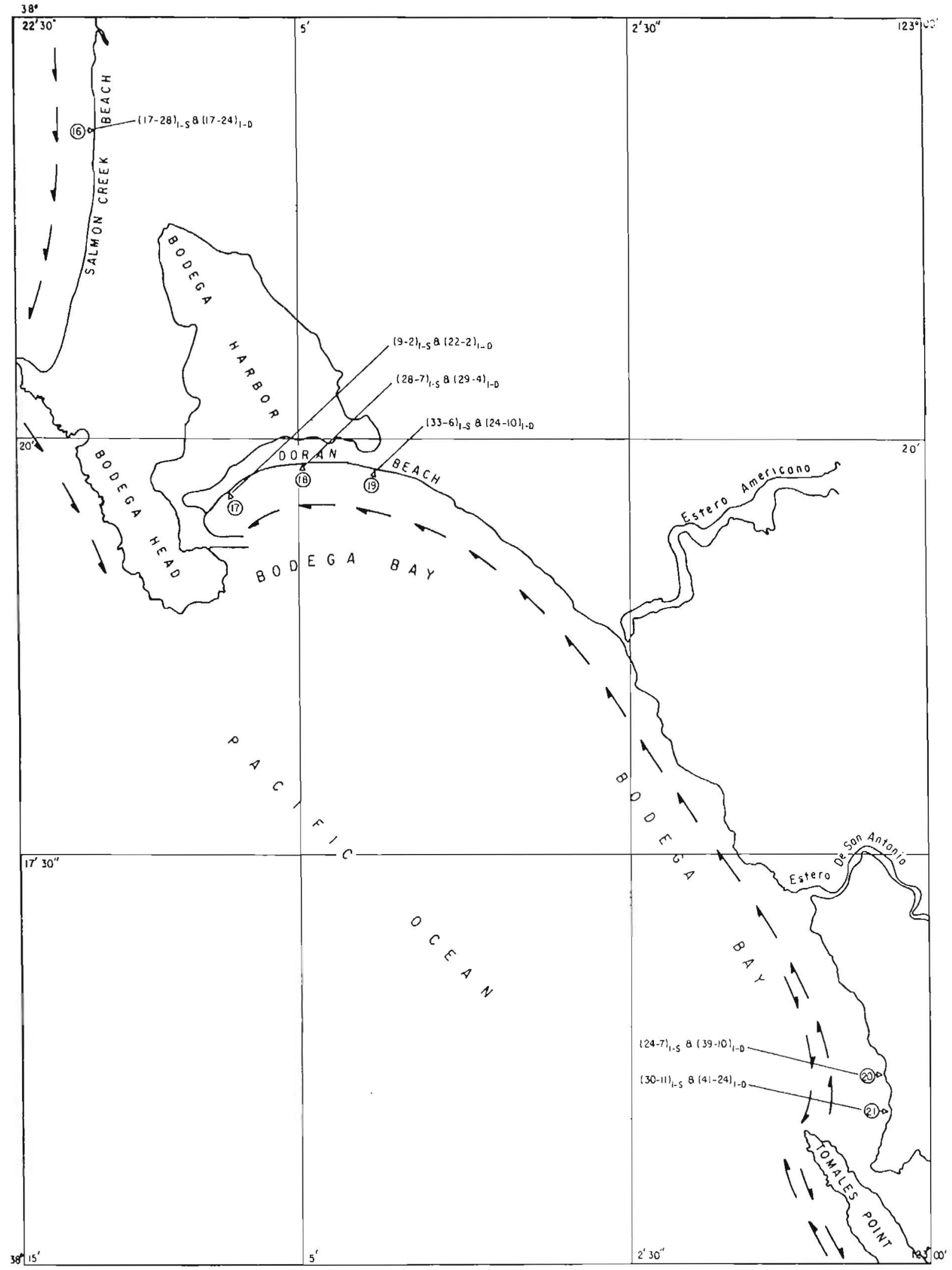

FIG 9 NUMBER AND LOCATION OF SAMPLES FROM BODEGA HEAD TO TOMALES POINT, THEIR THORIUM AND HEAVY MINERALS CONCENTRATION, AND THE DIRECTION OF MY0-8716 LITTORAL DRIFT. 


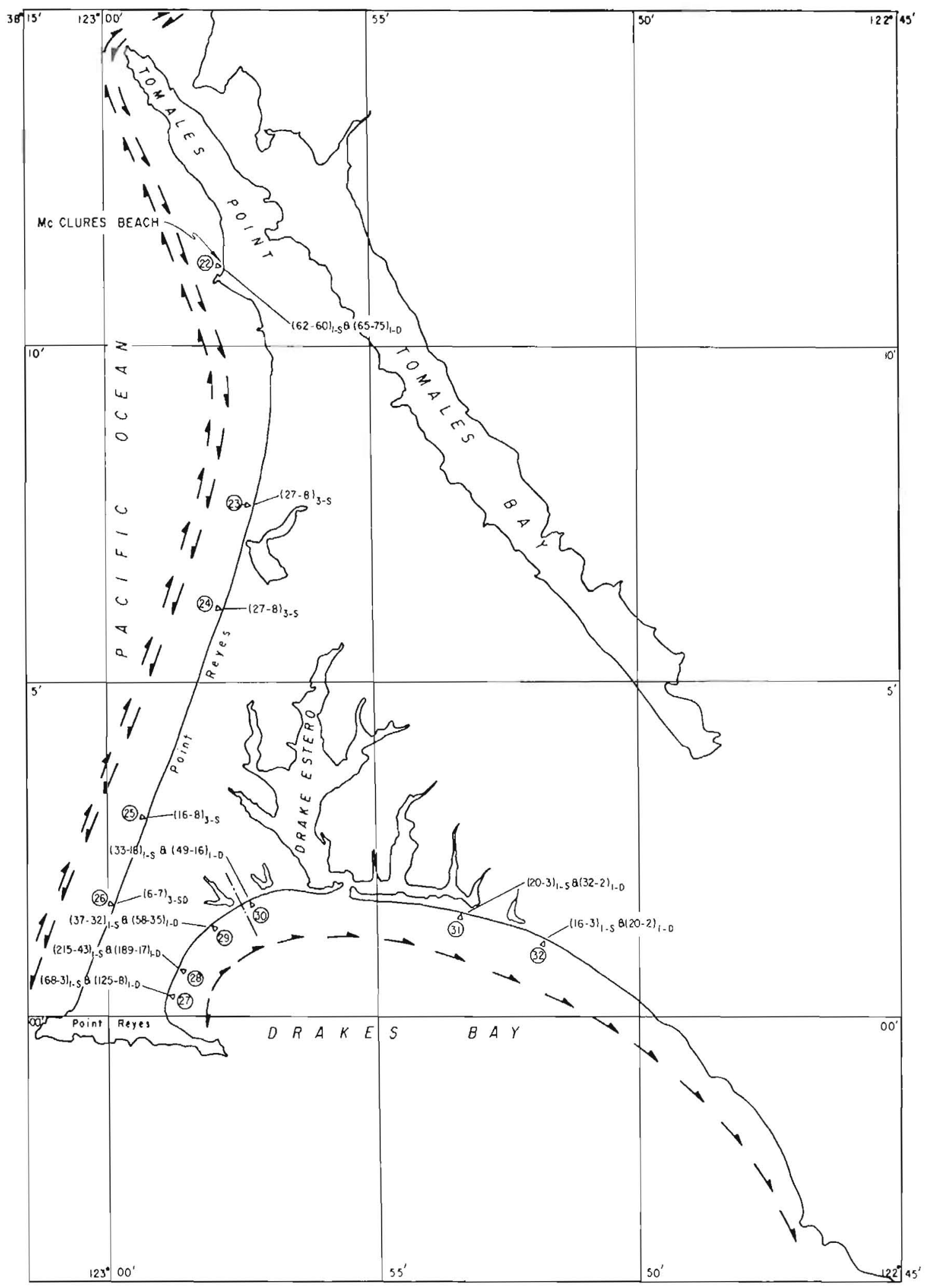

FIG. 10 NUMBER AND LOCATION OF SAMPLES FOR POINT REYES BEACH AND DRAKES BAY, THEIR THORIUM AND HEAVY MINERALS CONCENTRATION, HYOB7I7 AND THE DIRECTION OF LITTORAL DRIFT. 
tracer experiments (Russe11, 1961) that the re always is some dispersion and spreading of the tracer material in a direction opposed to the net drift. The eastward direction of 1ittoral drift for Drakes Bay has also been suggested by Trask (1958) where he observed that though the material at Drakes Cove gives no indication of the source of material, the presence of porphyry pebbles indicates an eastward direction of drift.

\section{Bolinas Bay (Fig. 11)}

It is believed that naturally radioactive thorium is added to the coast of Bolinas Bay from thortum-bearing granite rocks which outcrop at the seacoast at the southwest end of the bay. This material is then diluted in an eastward direction. This is confirmed by the decrease in the concentration of both thorium and heavy minerals. Thorium concentration decreased from $142 \mathrm{ppm}$. for sample 33 on the southwest side of Bolinas Bay to $30 \mathrm{ppm}$. at Stinson Beach (Fig. 11). Concentrations of heavy minerals decreased from 5 to 0.4 percent for the same locations. Wave refraction diagram strongly suggests an eastward direction of littoral drif $t$. In conclusion, based on the eastward decrease in thorium and heavy mineral concentrations and on the wave refraction diagram, it is believed that the littoral drift direction for Bolinas Bay is eastward. This is a 1 so confirmed by the presence of numerous pebbles of Miocene rocks along Stinson Beach, which can only come from the west. The se pebbles have been transported across the mouth of Bolinas lagoon in water at least 5 feet deep (Trask, 1958).

\section{San Francisco Bar (Fig. 11)}

of $f$ shore bottom samples taken in the vicinity of the San Francisco Bar show a very high concentration of thorium and heavy minerals on the top of the bar as indicated by sample 68 which has $162 \mathrm{ppm}$. thorium and 27 percent heavy minerals and by sample 65 which has $180 \mathrm{ppm}$. thorium and 44 percent heavy minerals. The concentration of thorium and heavy minerals decreases considerably on both sides of the bar as shown in Fig. 11.

A high concentration of both thorium and heavy minerals is also found in sample 48 in front of Fleischhacker $Z$ oo at Ocean Beach $(112 \mathrm{ppm}$, and 36 percent). The concentration decreases considerably both northwa rd and southward of Fleishhacker $\mathrm{Z}_{00}$ ( $\mathrm{Fig}, 12$ ). The very high concentration of thorium and heavy minerals for samples 68,65 , and 48 which are from the top of the San Francisco Bar, and the considerable decrease in the se concentrations on both sides of the bar suggests very strongly the migration of material from the north to the south along the top of the bar. This material then enters Ocean Beach in front of Fleishhacker $\mathrm{Z} O 0$ and is diluted in both a northward and southward direction. This is clearly demonstrated by the extensive sampling and analyses of Ocean Beach sands as explained in the following paragraph. 


\section{Beaches south of Golden Gate (Fig. 12)}

Extensive sampling was made of Ocean Beach to determine the location where the littoral material migrating from north of the Golden Gate enters the beach. Both surface and deep samples analyzed for thorium and heavy minera 1 concentrations for both size fractions 74 to $177 \mathrm{micron}$ and 125 to 250 micron showed a high concentration for the beach in sample 48 at Fleishhacker 200 . This high concentration decreased gradually and consistently southward from the source point at Fleishhacker Zoo (sample 48) to sample 53 near Sharp Park (Fig. 12).

The increase in concentration for samples 54 to 58 is attributed to sediments brought by several small streams which enter the coast in the vicinity of Sharp Park and Rockaway Beach. The se gullies flow through thorium-rich granite rocks. The high increase in thorium concentration for sample 59 near Point San Pedro is attributed to the thorium-bearing granite rocks which outcrop at the seacoast in this area.

The consistent gradual southward decrease in both the concentrations of thorium and heavy minerals for samples south of Fleishhacker Zoo indicate a southward direction of littoral drift during the sumer for this part of the coast. The less consistent northward decrease in concentrations for samples north of Fleishhacker 200 may suggest a northward drift for this part of the coast.

Ocean Beach is a fairly straight beach similar to Point Reyes Beach. Refraction diagrams drawn for the predominant wave conditions show that waves approach parallel to the shore. If waves along this part of the beach come in at an angle from the south or the north, they should produce a southward or northward drift, respectively. Prequently the waves along this part of the beach come in at an angle from the south (Trask, 1958). Such waves should produce a northward littoral current, which should transport sand toward the north.

Fig. 16 shows the direction of littoral drift along the reach of the California Coast between the Russian River and Point San Pedro based on the above analysis. The source of radioactive material (streams or rocks) as we 11 as the concentration of thorium and heavy minerals at different localities a re also indicated.

\section{B. TO STUDY THE VARIATION IN THORIUM CONCENTRATION ALONG A BEACH PROFILE (Fig. 13)}

The profile chosen for analysis in the vicinity of Location 30 on Drakes Bay (Fig. 10) showed a fairly constant concentration of both thorium and heavy minerals for a considerable distance on both sides of the mid-tide point. This is a fortunate condition since it shows that no significant error will be encountered if samples are collected exactly at mid-tide or several feet onshore or of $f$ shore from the point of mid-tide (Fig. 13). 


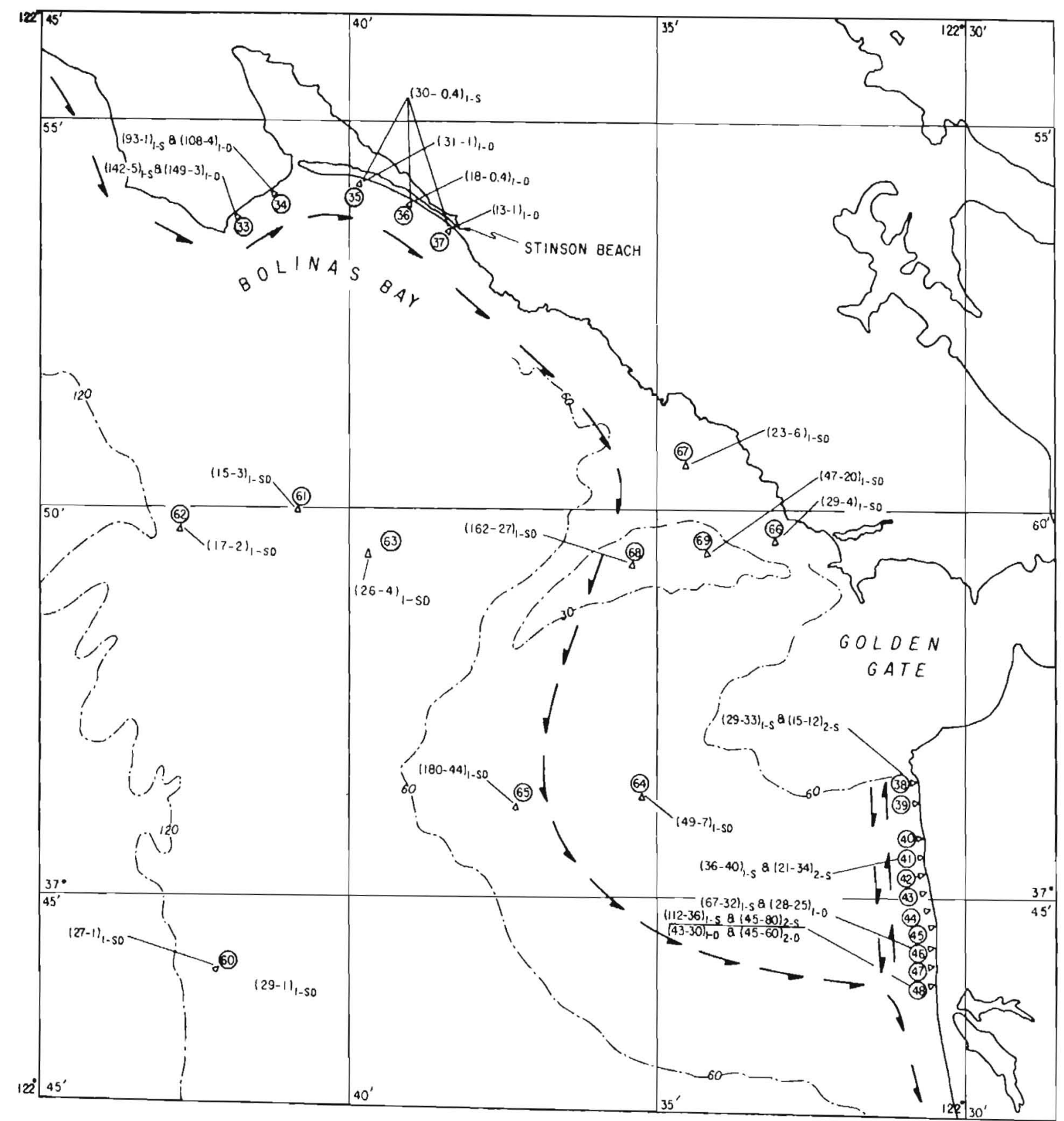

FIG. II NUMBER AND LOCATION OF SAMPLES FOR BOLINAS BAY AND SAN FRANCISCO HYO-8718 BAR, THEIR THORIUM AND HEAVY MINERALS CONCENTRATION, AND THE
DIRECTION OF LITTORAL DRIFT. 


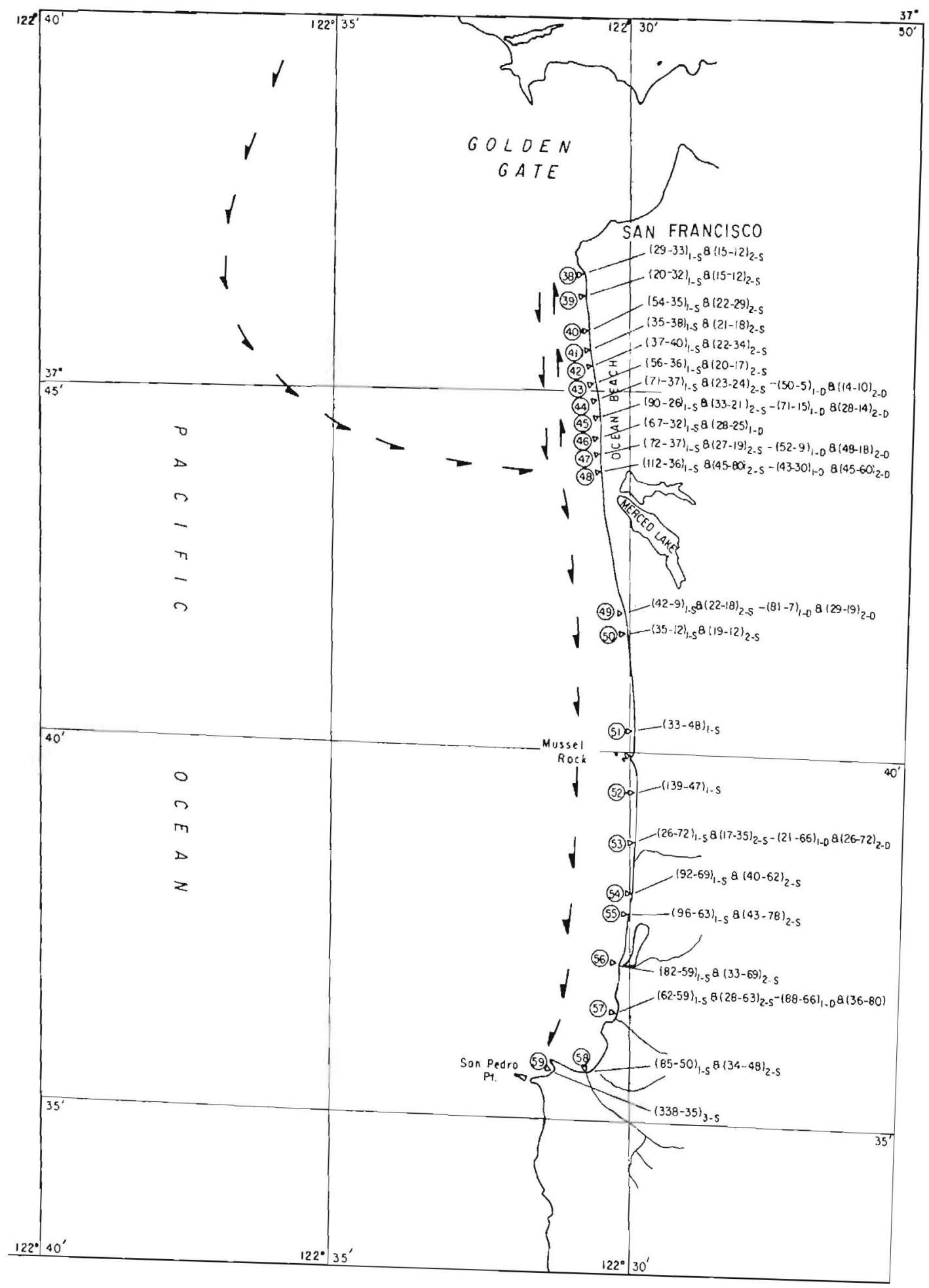

FIG. I2 NUMBER AND LOCATION OF SAMPLES SOUTH OF THE GOLDEN GATE, HYD-87I9 DIRECTION OF LITTORAL DRIFT. 

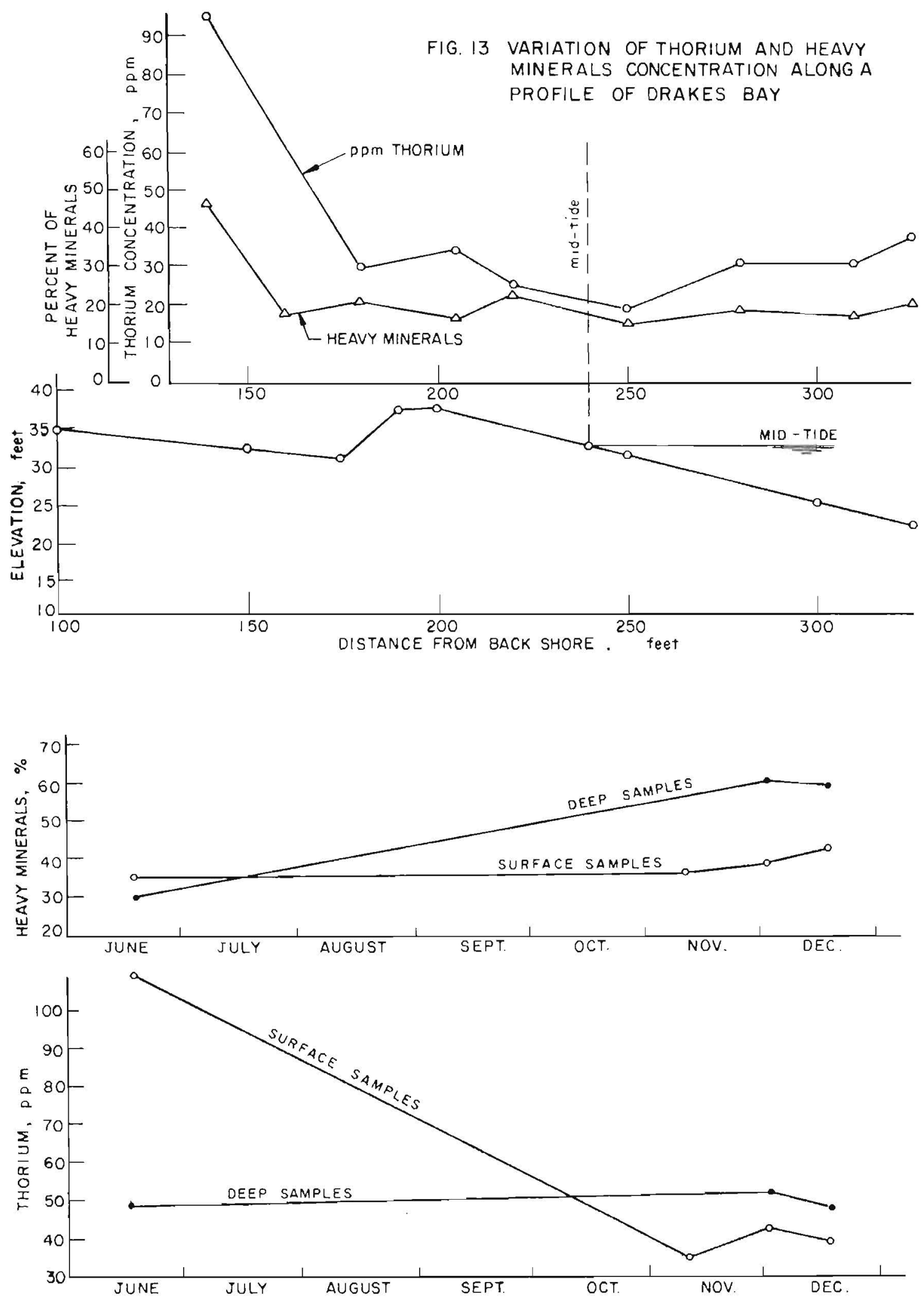

FIG. I4 VARIATION IN THORIUM AND HEAVY MINERALS CONCENTRATIONS WITH TIME AT OCEAN BEACH IN FRONT OF FLEISHHACKER ZOO, SAN FRANCISCO. 


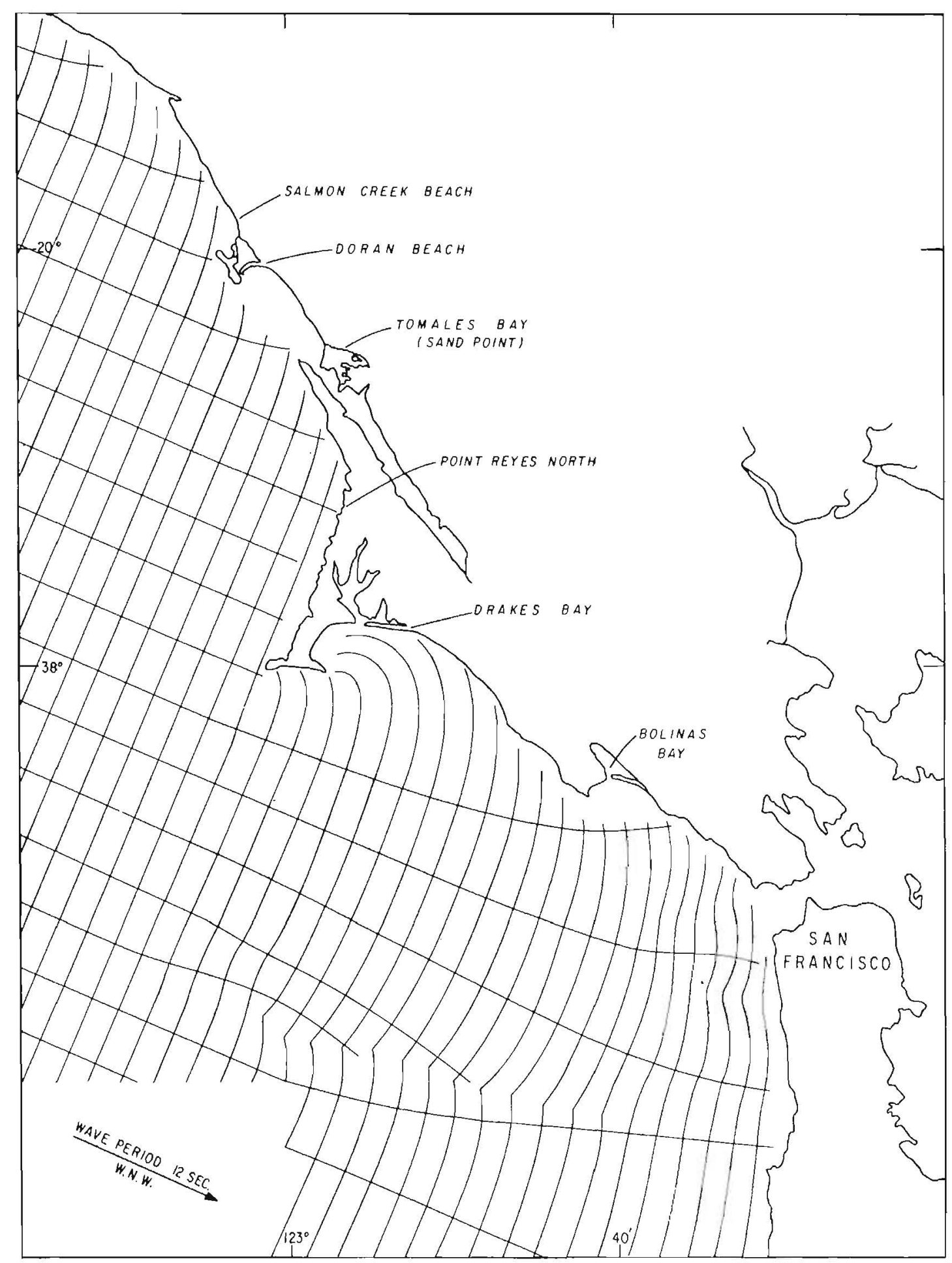

FIG. 15 WAVE REFRACTION DIAGRAMS FOR THE REACH UNDER STUDY 


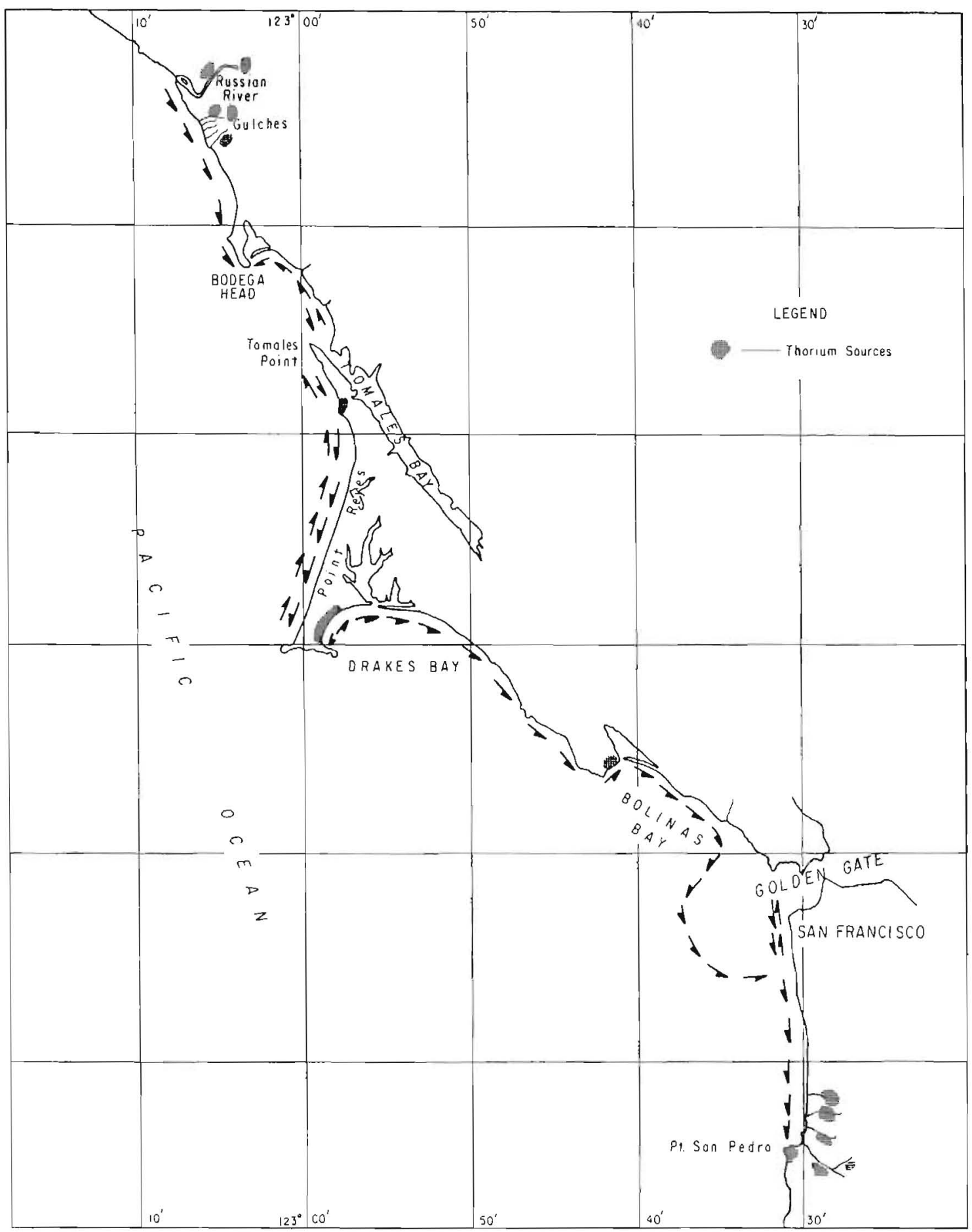

FIG. 16 THE DIRECTION OF LITTORAL DRIFT AND THE SOURCES OF HY0.8721 THORIUM (STREAMS AND ROCKS) FOR THE REACH UNDER STUDY 
The samples for this profile were collected during the low tide period on June 7,1961 . The average concentration for thorium and heavy minerals in the vicinity of the point of mid-tide we re found to be about $25 \mathrm{ppm}$. thorium and 19 percent heavy minerals which agzees with the results obtained for sample 30 which has a thorium concentration of $32 \mathrm{ppm}$. and 18 percent heavy minerals. Sample 30 was taken at mid-tide during the period between June 15 and 18,1961 .

Though 1ittle is known at present about sorting of sedimentary beach material due to its selective onshore-of fhore transport by wind or shallow water waves (Ippen, 1955), the increase in the concentrations of heavy minerals and thorium near the backshore of the profile under study may be attributed to wind sorting as it is generally observed that black sands tend to concentrate on the backshore of beaches; however, this phenomenon needs to be further investigated.

C. TO STUDY THE VARIATION IN THORIUM CONCENTRATION WITH TIME AT A SPECIFIC LOCATION ON A BEACH (Pig. 14)

The samples analyzed for the part of Ocean Beach in front of Fleishhacker 200 were collected at mid-tide during the period between June 17 and December 18, 1961. The se samples showed a lower thorium concentration during the fall season than during the summer season (Pig. 14). This may be because during the fall season waves along Ocean Beach frequently come in at an angle from the south. Such waves should produce a northward current, which would transport sand northward. If sand is transported toward the north at Ocean Beach, the concentration of thorium at Fleishhacker consequently will decrease, since it is believed that the reason for high thorium concentration is material migrating from the north along the top of the San Francisco Bar and entering Ocean Beach in the vicinity of Fleishhacker $Z$ oo.

\section{SUMMARY AND CONCLUSIONS}

Tracers have already shown themselves to be most useful in situations where there is uncertainty about the movement of sediments. The re are beaches for example where the re is doubt concerning the direction of 1ittoral drift and where a tracer experiment which might reveal the direction of movement would be justified.

The method of using radioactive thorium as a tracer for sand movement along a portion of the California Coast presented itself in that the re are discrete places along the coast where rivers flowing through thorium-rich granite outcrops reach the coast or where the thorium-rich granite itse $1 f$ crops at the seacoast.

This method of assaying for naturally radioactive thorium as a means of detecting the direction of drift of sand along a seacoast was investigated and applied to the reach of the Coast of California from the Russian 
River mouth to Point San Pedro. The method proved to be very efficient for qualitative results and rather simple compared to mineralogical analyses.

The difficulties in this technique are:

1. The low counting rate for thorium and uranium at high energy leve $1 \mathrm{~s}(2.63$ and $1.86 \mathrm{mev}$. respective $1 \mathrm{y})$ to avoid the interference from the 1.46 mev. peak $\mathrm{f}$ rom $\mathrm{K} 40$ in the potassium minerals. This was avoided by assaying for the heavy minerals of the sand samples separated by bromoform to get rid of the potassium minerals present and consequently counting for the $0.188 \mathrm{mev}$. peak from $\mathrm{Ra}^{22} 6$ in the uranium series and the $0.238 \mathrm{mev}$. $\mathrm{Pb}^{212}$ peak in the thorium series which will give a higher counting rate.

2. The method requires that the sand samples analyzed should be in good contact with the scintillation crystal in order to obtain sufficient counts for analysis, but the thickness of the sample layer must not be so great that the photopeaks are masked by Compton scattered radiation from within the sample. In order to get good contact be tween the sand samples analyzed and the scintillation crystal, the samples should be placed around the crystal, but this will require a large sample size which is not available in this study since the weight of the heavy minerals assayed is generally less than 10 grams. For this reason the heavy mineral samples were placed on the top of the scintillation crystal and correction for the sample thickness was made as indicated in Appendix III.

3. Since the gamma-rays concerned are from natura1 sources of low activity it was necessary to minimize the total count-to-background ratio, which was done by working in a laboratory of a constant low background.

The three factors considered in determining the direction of 1ittora 1 sand drift along the reach of the California Coast under study are:

1. The concentration of thorium (in parts per million) in the heavy minerals of a limited size fraction of the sand samples analyzed. in (1).

2. The percent of heavy minerals in the same size fraction used

3. Wave refraction diagrams.

A decrease in the concentration of thorium and heavy minerals from the source area indicated alongshore drift in the direction of decrease of both parameters. In order for the decrease in concentration of thorium and heavy minerals to indicate the direction of 1 ittoral drift, this decrease in concentration should be due to progressive sorting caused by the alongshore current on the beach sands. For this reason the effect of loca 1 sorting on the beach sands should be eliminated. This has been done by comparisons between sample concentrations for a very small fraction, i.e.., 74 to 177 microns. Wave refraction patterns give a good indication of the 
direction of sand drifting along a coast since it is agreed that the 1 ittoral drift is caused by the alongshore energy component of waves breaking at an angle to the shore.

Precision of the method depends on the abundance of thorium in the sand samples. Comparisons of composition from one sample to another can at best indicate genesis. if the changes are la rge. For example the virtual absence of thorium in one sample and the presence of say $15 \mathrm{ppm}$. thorium in an adjacent sample, strongly suggests a local source of thorium. On the other hand, if $15 \mathrm{ppm}$. of one sample is thorium, and $20 \mathrm{ppm}$. of another is thorium no significant conclusion may be drawn except if we have a consistent decreasing trend from one sample to another.

Based on the distribution of beach samples and their thorium and heavy mineral concentrations and wave refraction diagrams, it is believed that the pattern of sand movement along the California Coast from the Russian River mouth to Point San Pedro takes the following form: For the part of the coast north of the Russian River mouth though the refraction diagrams indicate a southward drift, the concentrations of both thorium and heavy minerals do not show any consistent or significant decrease in any direction which suggests a reversal direction of littoral drift for this part.

South of the Russian River mouth the concentration of both thorium and heavy minera1s decreases gradually and consistent1y in a southward direction. This indicates a southward direction of sand movement which is also confirmed by the wave refraction diagram pattern for this part.

For Bodega Bay, although a northward direction of drift is indicated by the northward decrease in concentration of both thorium and heavy minera1s, the great preponderance of chert and greenstone among the pebbles on Point Reyes Beach indicates that most of the beach material comes from the mainland east of the Point Reyes Peninsula, because no rocks of this character are found on the Peninsula which shows a southward direction of drift. This is also confirmed by the wave refraction diagram pattern.

Wave refraction diagrams drawn for Point Reyes Beach for W.N.W. waves with a period of 12 seconds which represents the predominant wave condition in this part, show that the direction of wave approach is parallel to the shore. However, waves approaching the shore from the north or south of the W.N.W. direction will result in a southward or northward littoral drift, respectively, which indicates that sand movement along Point Reyes Beach is subject to reversals in direction.

For Drakes Bay the decrease in both thorium and heavy minerals concentration to the east, wave refraction diagram pattern and the presence of porphyry pebbles all indicate an eastward direction of 1ittoral drift. 
The eastward decrease in thorium and heavy minerals concentration, wave refraction diagram pattern, and the presence of numerous pebbles of Miocene rocks along Stinson Beach, which can only come from the west, a 11 indicate an eastward direction of sand movement along Bolinas Bay.

The high concentration of both thorium and heavy minerals for the samples taken from the top of the San Francisco Bar and the respective northward and southward decrease of both these concentrations north and south the top of the bar in front of Fleishhacker 200 at Ocean Beach, suggests very strongly the migration of material from the north to the south along the top of the bar. This material then enters Ocean Beach in front of Pleishhacker $Z 00$ and is diluted in both a northward and southward direction.

\section{ACK NOWLE DGEMENTS}

The author expresses his appreciation and sincere thanks to Professors J. W. Johnson, P. R. Day and W. J. Kaufman for their cooperation, inspiration and guidance throughout the investigation.

Professor J. W. Johnson, who was the chairman of the thesis committee is to be acknowledged not only for his invaluable guidance but also for procuring funds necessary for the investigation.

Thanks are also due to Professor $H . A$. Einste in and Dr. R. B. Krone with whom the author had many interesting and informative discussions, to Dr. G. Gordon of the Department of Minera 1 Technology for making available the gamma-ray spectrometer and $h$ is continuous help during the experimental work.

The National Science Foundation's financial support of the work is gra tefully acknowledged. 


\section{BIBLIOGRA PHY}

1. Adams, John A. S., et a1, De te rmination of thorium and uranium in sedimentary rocks by two independent methods. Geochemica et Cosmochemica Acta. Vo1. 13, pp. 270-279, 1958.

2. Arlman, J. J., et a1, Movement of bottom sediment in coastal waters by currents and waves; measurements with the aid of radioactive tracers in The Ne the rlands. Delta dienst, Rijkswaterstaat, Ministry of Transport and Waterstaat, The Netherlands. Progress Report, June 1957, $63 \mathrm{pp}$.

A1so, Beach Erosion Board, Technical Memorandum No. 105, 56 pp., March 1958.

3. Bajorunas, L., Littoral transport in the Great Lakes. Proceedings of Seventh Conference on Coastal Engineering, pp. 326-431, 1961.

4. Bascom, w., The control of stream outlets by wave refraction. The Journal of Geology, Vo1. 62, No. 6, November 1954.

5. Caldwe11, J. M., Wave action and sand movement near Anaheim Bay, California. Beach arosion Board Tech. Memo. No. 68, 21 pp. 1956.

6. Chieruzzi, R. and $R$. F. Baker, The investigation of bluff recession along Lake Erie. Engineering Experiment Station, College of Engineering, The Chio State University, Columbus, Ohio, July 1958.

7. Crouthame1, C. E., Applied Gamma-ray spectrometry, Pergamon Press, 1960.

8. Davidisson, J., Investigation of sand movement using radioactive sand. Lund studies in Geography, Series A, Physical Geography 12, pp. 107-126, 1958 .

9. Eaton, R. O., Littoral processes on sandy coast. Proceedings First Conference on Coastal ingineering, pp. 140-154, 1951.

10. Einstein, H. A., The bed load function for sediment transportation in open channel flows. USIA Soil Conservation Service Tech. Bul1. No. 1026. September 1950.

11. Forest, G., and P. Jaffry, Emploi de traceurs radioactifs dans l'etude des mouvements de sediments sous l'effet de la houle et des courants. Communication presentee au 7 e Congres de 1'Association Internationa 1 de Recherches Hydrauliques, Lisbon, July 1957, 10 pp.

12. Germain, J., et al, Utilisation des traceurs radioactifs pour 1'etude des mouvements de sediments marins. Proceedings Sixth Conference on Coastal Engineering, pp. 314-325, 1958.

13. Glasstone, S., Source book on Atomic Energy - 2nd Edition, 1958. 
14. Goldberg, B. D. and D. L. Inman, Neutron irradiated quartz as a tracer of sand movements. Bulletin of the Geological Society of Ame rica, Vo1. 66, pp. 611-613, 1955 .

15. Gibert, A., et a 1, Tracing sand movement under sea water with Ag 110. 2nd United Nations Conference on the Peaceful Uses of Atomic Energy. A/Conf. 15/P/1820. Lisbon, Portuga 1, June 24, 1958.

16. Grant, U. S. and P. P. Shepard, Changes along the California Coast. Geological Society of America Proc. pp. 75-76, 1936.

17. Ibid, Magnitude of some shore processes in Southern California. Geologica1 Society of America Proc. pp. 239-240, 1937.

18. Ibid, Shallow water sediment shifting processes along the Southern California Coast. 6th Pac. Sci. Cong. Proc., vol. 2, pp. 801-805, 1939.

19. Ibid, Effect of type of waves breaking on shore processes. Geological Society of America Bulletin Vo1. 57, p. 1252, 1946.

20. Halcrow, Sir William, et al, Littoral drift at Dungeness. Hydraulic Research, Vol. 16, 1960, D. 137, No. 51. International Association for Hydraulic Research, September 1961.

21. Handin, J. W., The source, transportation and deposition of beach sediments in Southern California. Beach Erosion Board Technical Memorandum No. 22, 1951.

22. Hiranandani, M. G. and C. V. Gole, Use of radioactive tracer for the study of sediment movement of $\mathrm{f}$ Bombay Harbor. Technical Memorandum 1 , Central Water and Power Research Station, Poona, India, June 1960.

23. Hours, $R_{\text {, }}$, et al, Methode d'etude de l'evolution des plages par traceurs radioactifs. Travaux du Centre de Recherches et d'Etudes Oceanographiques, 1, No. 11, November 1955.

24. Hof stadter, R., et. a1, Gama-ray spectroscopy with crystal of No.1 (T1). Nucleonics, Vol. 7, No. 3, pp. 32-37, 1950.

25. Hurley, P. M., Direct radiometric measurements by gama-ray scintillation spectrometer. Parts I and II. Bulletin Geological Society of America, Vo1. 67, pp. 395-412, 1956.

26. Hutton, C. O., Uranium, thorite, and thorium monasite from black sand pay streaks, San Mateo County, Calif. Geological Society of America Bulletin, Vo1. 62, No. 12, pp. 1518-1519, 1951.

27. Ijima, $T$., et a1, The observation of sand movement by radioactive glass sand at the Isohama on the Pacific Coast. Hydraulic Research Vo1. 16, 1960 , p. 278, No. 5. Inte rnationa 1 Assoc. for Hydraulic Research. 
28. Inman, D. L., Sorting of sediments in the light of fluid mechanics, Journal of Sedimentary Petrology, Vo1. 19, No. 2, pp. 51-70, 1949.

29. Inman, D. L, and T. K. Chamberlain, Tracing beach sand movement with irradiated quartz. Journal of Geophysical Research, Vo1. 64, No. 1, 1959.

30. Inose, S., The measurement of 1ittoral drift by radio-isotopes. (Hokkaido Development Bureau, Japan) The Dock and Harbor Authority, pp. 284-288, January 1956.

31. Inose, S., et a 1 , The field experiment of littoral drift using radioactive glass sand. Internat. Conference on the Peaceful Uses of Atomic Energy. A/Conf. 8/D/1053, Japan. July 11, 1955.

32. Ippen, A. T. and P. S. Eagleson, A study of sediment sorting by waves shoaling on a plane beach. Beach Erosion Board Technical Memorandum No. $63,1955$.

33. Ishihara, $T$. and $T$. Sawaragi, On the critical velocity and depth of water for sand movement and the rate of sand transport due to wave action. Proc. of Seventh Conference on Coastal Engineering in Japan, pp. 47-57, 1960 .

34. Iwagaki, $Y$. and $T$. Sawaragi, A new me thod for estimation of the rate of littoral sand drift. Proc. Seventh Conference for Coastal Engineering in Japan, pp. 59-67, 1960.

35. Johnson, D. W., Shore processes and shore line development. John Wiley \& Sons, Inc. 1919.

36. Johnson, J. W., Sand transport by littoral currents, 5th Hydraulic Conference Bulletin 34. State University of rowa, Studies in Engineering, 1952 .

37. Ibid, Dynamics of nearshore sediment movement. Bulletin, American Assoc. Pet. Geo1., Vo1. 40, No. 9, pp. 2211-2232, 1956.

38. Ibid, The littoral drift problem at shoreline harbors. Journal of the Waterways and Harbors Division, Proc. ASCE, April, 1957.

39. Ibid, The supply and loss of sand to the coast. Jour. of the Wate rways and Harbors Division, Proc. ASCE, September 1959.

40. Kahn, B., and W. S. Lyon, Scintillation spectrometer in radio-chemical analysis. Nucleonics, Vo1. 11, No. 11, pp. 61-63, 1953.

41. Kaufman, W. J., P.H. 115 class notes, 1960. 
42. Krone, R. B., H. A. Binstein, W. J. Kaufman, and N. W. Snyder, Silt transport studies utilizing radioisotopes. First Annual Progress Report, Berkeley, California. Hydraulic Engineering Laboratory and Sanitary Engineering Research Laboratory, University of California, $118 \mathrm{pp}$. December 1957.

43. Krone, R. B., H. A. Einstein, W. J. Kaufman, and G. T. Orlob, Silt transport studies utilizing radioisotopes. Second Annual Progress Report, Berkeley, California. Ibid, 123 pp. February 1959.

44. Ibid, Third Annual Progress Report, Ibid, 52 pp., September 1960.

45. Ibid, Methods for tracing estuarial sediment transport processes, Ibid, October 1960.

46. Krone, R, B., An underwater scintillation detector for gama emitters. A manua1. Berkeley, California, Ibid, 25 pp. July 1960.

47. Krumbein and Pettijohn, Manual of sedimentary petrography, D. AppletonCentury Co., Inc., 1938.

48. K rumbein, W. C., Shore currents and sand movement on a model beach. Beach Erosion Board Technical Memorandum No. 7, 44 pp., 1944.

49. McMaster, R. L., Mineralogy as an indicator of beach sand movement along the Rhode Island shore. Journal Sedimentary Petrology, Vol. 30, No. 3, pp. 404-413, 1960.

50. Moro, J., Uses of the gamma-ray spectrometer in mineral exploration. Geophysics, Vo1. 25, No. 5, pp. 1054-1076, 1960.

51. Nationa1 Marine Consultants, Wave statistics for seven deep water stations along the California Coast. U. S. Army Engineer Districts, Los Angeles and San Prancisco, California, December 1960.

52. Pincus, H. J., The motion of sediment along the south shore of Lake Erie. Proc. Fourth Conference for Coasta1 Engineering, pp. 119-146, 1954.

53. Putman, J. L., and D. B. Smith, Radioactive trace $r$ techniques for sand and silt movements under water. International Journal of Applied Radiation and Isotopes $1(1 / 2)-24-32,1956$.

54. Radioactive tracers for the study of sand movements, Report on an experiment carried out in Liverpool Bay in 1958. nSIR, Hydraulic Research Station, Howbery Park, Wallingford, Berks, England, 1958.

55. Reid, W. J., Coastal experiments with radioactive tracers. The Dock and Harbor Authority (England), 39 (453) 84-88, July 1958. 
36. Rittenhouse, G., Sources of modern sands in the middle Rio Grande Valley, New Mexico. The Journal of Geology, Vo1. LII, No. 3, May 1944.

57. Russe11, R. C., The use of fluorescent tracers for the measurement of littoral drift. Proc. Seventh Conference on Coastal Engineering, PP. 418-444, 1961 .

58. Saville, T., Jr., Model study of sand transport. Transactions, American Geophysical Union, Vo1. 31, No. 4, pp. 555-565, August 1950.

59. Sauvage De Saint Marc, G., Transport 1ittoral formation de fleches et de Tombolos. Proc. Fifth Conference Coastal Engineering, pp. 296-328, 1955.

60. Shepard, F. P., Mass movements in submarine canyon heads. Transactions, American Geophysical Union, Vo1. 32, No. 3, pp. 405-418, June 1951.

61. Shepard, F. P. and B. C. La Fond, Sand movements along Scripps Institution Pier. American Journal Science, Vo1. 238, pp. 272-285, 1940.

62. Smith, D. B., Radioactive methods for labeling and tracing sand and pebbles in investigations of 1ittoral drift. UNESCO/NS/RIC/63. London. Pergamon Press, 12 pp, 1957.

63. Steers, J. A., and D. B. Smith, Detection of movement of pebbles on the sea floor by radioactive methods. Geographical Journal (London), 122 (part 3): 343-345, 1956 .

64. Svasek, J. N. and H. Engel, Use of radioactive tracer for the measurement of sediment transport in The Netherlands. Proc. Seventh Conference on Coasta 1 Engineering, 1961.

65. Trask, P. D., Source of Beach sand at Santa Barbara, California as indicated by mineral grain studies. Beach Erosion Board Technical Memorandum. No. 28, 1952 .

66. Trask, P. D., Movement of sand around Southern California Promontories, Beach Erosion Board Technical Memorandum No, 76, 1955.

67. Trask, P. D., Beaches near San Francisco, California. I. E, R. University of California Wave Research Laboratory, series 14, issue 21, 1958.

68. Trask, P. D., Mechanical analysis of beaches near San Francisco, Calif. Ibid, series 14, issue 22, 1959.

69. Vendrov, S. L., Emploi des luminophores pour 1'etude des mouvements d'alluvions long des rives des barrages. Transport Fluvial, 4, 1957.

70. Wilson, $B . W_{*}$, Methods of determining sand \& silt movement along the Coast, in Estuaries and in Maritime Rivers. 20th International Navigation Congress, Baltimore 1961, section 2, subject 5 .

71. Zenkovich, V. P., Emploi des luminophores pour 1'etude de mouvement des alluvions sablonneuses, Bulletin, C.O.E.C. 10 (5). May 1958. 
The Gamma-Ray Spectrometer

The device by which gamma rays of a specific energy can be discriminated from all other gama rays is called a gama-ray spectrometer. It consists of:

(1) A scintillation detector, and (2) a pulse height analyzer.

\section{The scintillation detector}

Scintillation counting, one of the oldest radiation detection techniques, has gone through several developmental phases. The visually detected scintillations of energetic alpha-particles absorbed in thin films of zin-sulfide crystal was first noted by Sir William Crooks and also independent1y by Blster and Geitel in 1903. In the 1930's the visual scintillation counter became obsolete and the next 20 years were characterized by the rapid growth and development of electronic counting techniques. Gas-filled ionization chambers in which the incident charged particles generated ion pairs were used as the basic detector. With the se gas-filled systems, there are three well defined operating methods - the ionization detector, the proportional counter, and the Geiger-Mullex counter. With the development of sensitive photomultiplier tubes, the scintillation counter has regained its former place in research.

A scintillation detector utilizes minute flashes of light produced when gamma emission gives up energy to atoms in a crysta1, organic polymer, or organic 1iquid. Since there are greater densities of atoms in a solid than in a gas, the chances for collision between an incident emission and an atom are greate $x$ and give the detector a correspondingly increased efficiency. The light flashes are of short duration, and interaction at one part of the detector does not paralyze the remainder. Some of the more common devices are:

\section{a - Tha11ium activated NaI Crysta 1}

A sodium-iodide crystal with a trace of thallium produces a light flash with an intensity that is proportional to the absorbed energy. Gamma-spectrometry is possible because the intensity of the light pulses is proportional to the gamma radiation. The crystal used in this device is $5 \mathrm{~cm}$. long by $5 \mathrm{~cm}$. In diameter. The advantages of high efficiency and the differing response for different emission energies make this detector best suited for low counting measurements. 


\section{b - The Photomultip1ier tube}

The photomultiplier tube serves to convert the smal1 1 ight pulse it sees in the clear crysta 1 into an avalanche of electrons which are received by the next instrument as an electrical pulse whose magnitude depends upon the energy of the initial gamma quantum.

\section{The pulse height analysis}

The electron pulse from the photomultiplier tube appears something 1ike the following figure:

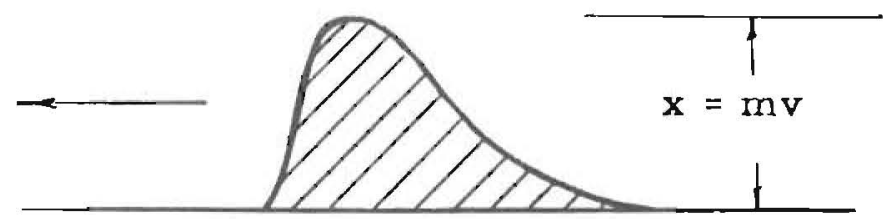

The maximum amplitude of the pulse corresponding to some voltage potential (say $x$-Millivolts) is next amplified (say to $y$-volts at maximum height).

Since it is difficult to measure the maximum height of this pulse when it lasts for such a brief period, the pulse is reshaped by an appropriate circuit called the widener circuit to give it an approximately rectangular shape as shown below:

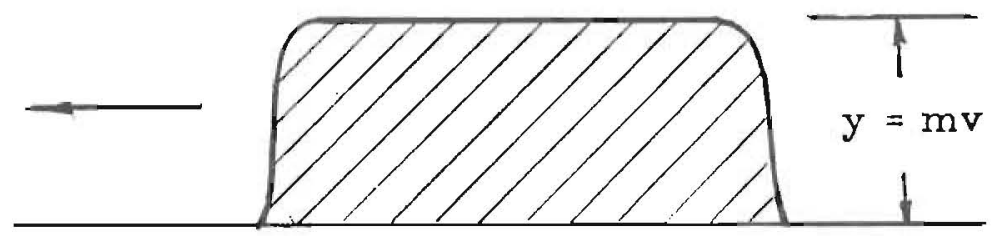

The height of the widened pulse is equal to the maximum height of the pulse before it was reshaped.

The reshaped pulse is now fed into a circuit called the discriminator which has been preset to detect pulses which fall within some definite voltage range.

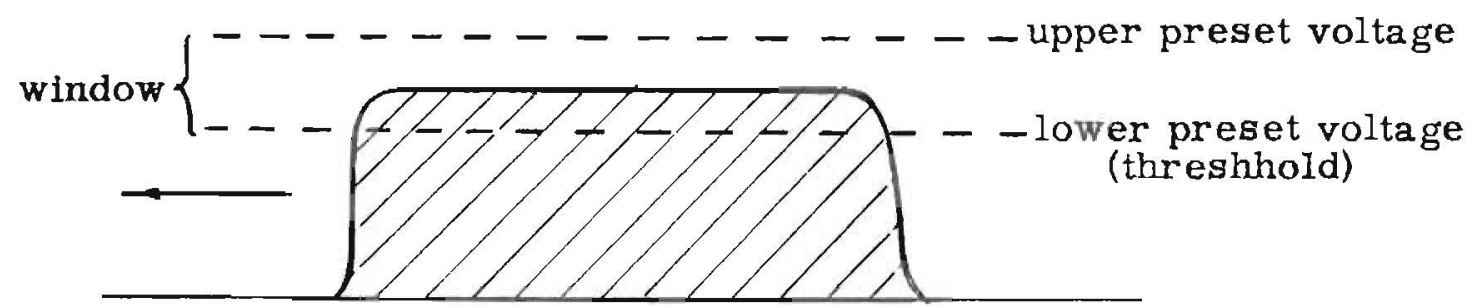


This voltage range is termed a window. However, in order for this circuit to operate effectively, it must measure the pulse height sometime after the maximum voltage has reached the circuit and not while the pulse is rising up to its maximum value. The pulse height must be measured at about this point.

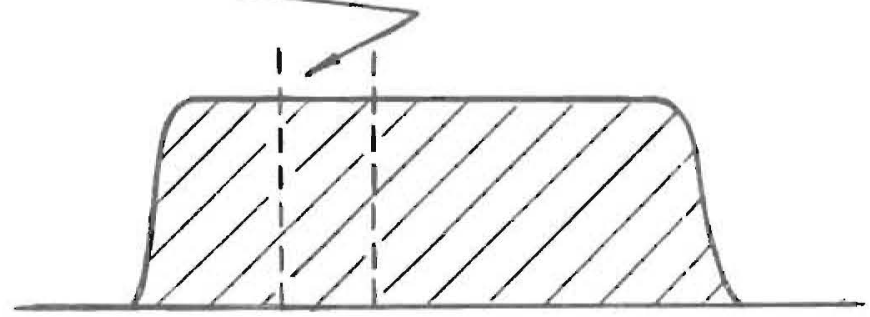

In order to achieve this result another circuit is employed called the gate generator circuit. This circuit generates a signal and sends it to the discriminator which is measuring the height of the pulse. The generation of this signal in the gate generator occurs at the first sign of a pulse going to the discriminator from the amplifier, but this gate signal does not arrive at the discriminator until shortly after the pulse, whose height is to be measured, has reached the discriminator and has had time to rise up to its maximum potentia1. The pulse height measuring circuit, i.e., the discriminator, will not work until the gate signal has arrived, thus giving the pulse time to reach its maximum height. The true value of the maximum pulse height is compared with the two preset values. If the pulse height is greater than the lower preset voltage, the threshold, but not greater than the upper one, threshold plus window, it causes a uniform pulse signal to be sent on to the scaling unit, and one quantum of gamma radiation, whose energy falls within the energy range represented by the window, has been detected. This energy range can be found after calibration of the spectrometer. Pulses having heights less than the lower preset voltage or higher than the upper preset voltage are not racorded for this particular window.

The gamma-ray spectrometer used in this study is a 3 -channe 1 Pedersen electronic mode1 (Figs. 17, 18). 


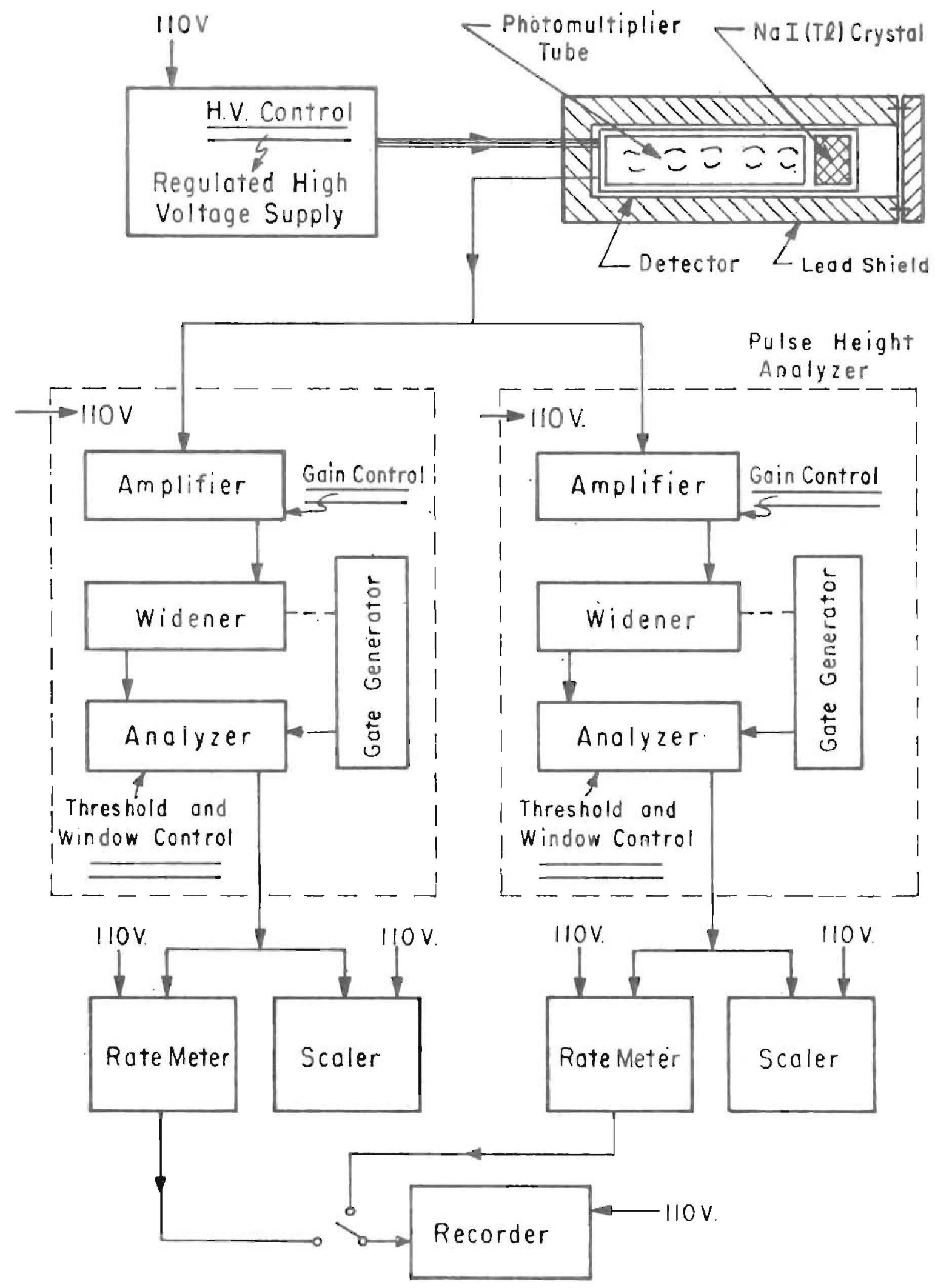

FIG. 17 COMPONENTS OF A 2-CHANNEL GAMMA-RAY SPECTROMETER 


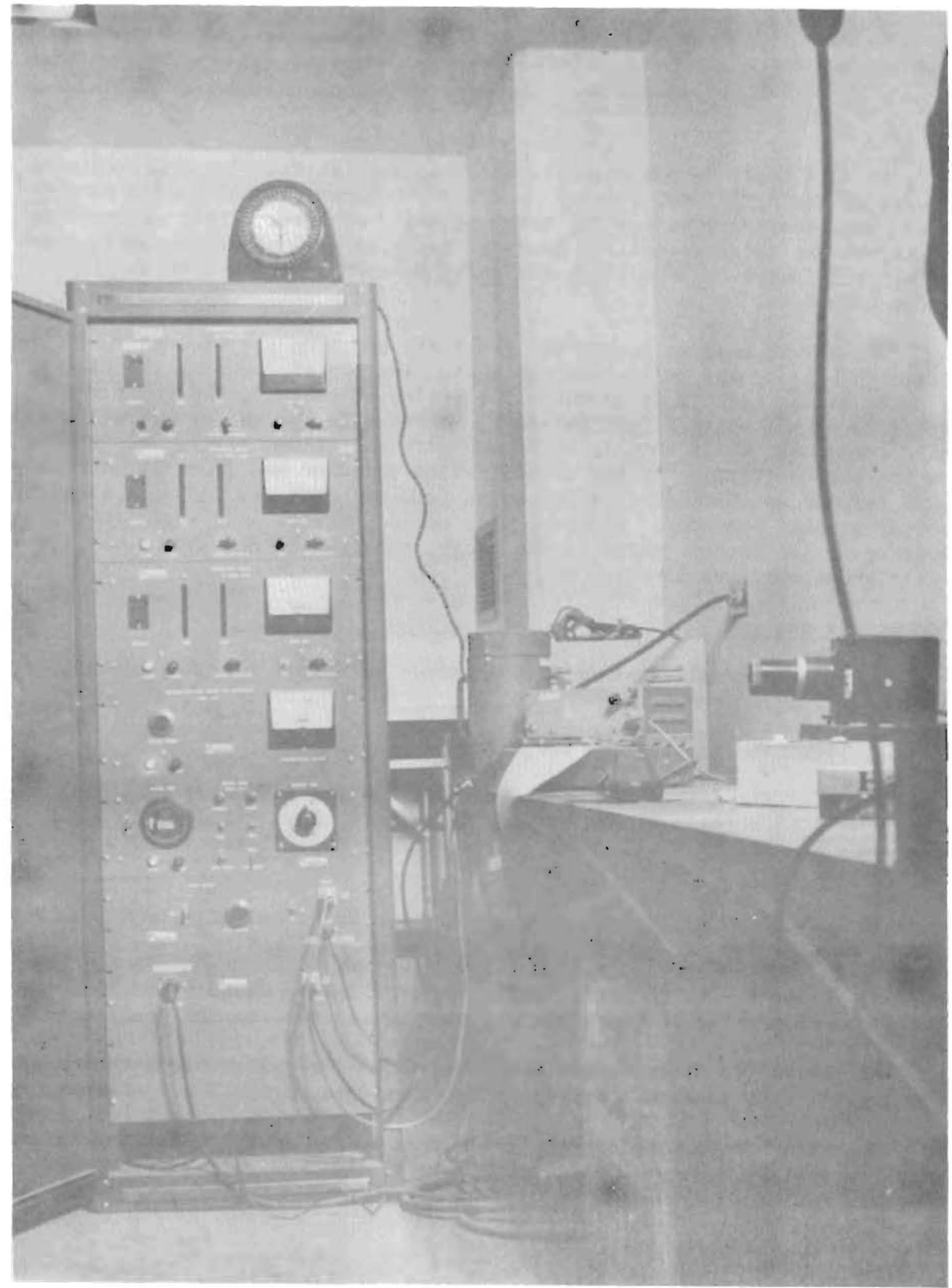

FIG. 18 GENERAL VIEW OF THE GAMMA-RAY SPECTROMETER USED 
APPENDIX II

ADJUSTING THE GAMMA-RAY SPECTROMETER

In this study only 2 channels were adjusted so that the upper channe 1 counts at the $0.188 \mathrm{mev}$. uranium peak and the lower channel counts at the 0.238 mev. thorium peak for the heavy minerals assayed. There was no need to adjust the third channe 1 to count at the 1.46 mev. potassium peak, since it was eliminated by separating the heavy mineralsfrom the sand sample using bromoform.

The method used to obtain the gamma ray spectrum graphs used to illustrate this study may be of some interest. Instead of lowering the bias on a pulse gating circuit as in the usual method of sweeping the gamma ray spectrum with a pulse height analyzer, the bias on the gating circuit was held constant. While holding the pulse gate at a fixed leve1, the voltage on the photomultiplier in the scintillation detector was linearly increased with respect to $t$ ime. The output pulse from the gate was fed to a 1 inearly moving graphic recorder. Although this method results in a logarithmic spacing of the photon energy on the graph, good resolution throughout the whole gamma spectrum is obtained.

Adjustment outline

1. Plot the relationship between anode volt dial and photomultiplier scale (Fig. 19).

2. Plot the spectra for the standard samples (Fig. 20).

3. Plot the energy of the photon peak for the standards (Fig. 21) vs. the anode dial reading at which the peak appears which yields a straight line on a semi-logarithmic paper. Sucy a graph facilitates the determination of the energies of photon peaks.

4. Ready the spectrometer by setting all dials and adjustments in the proper places.

5. Place the calibrating sample (Cs 137) in the machine and find the voltage dial setting at which the big peak is centered on the lower channel.

6. Leave the voltage dial alone and adjust the attenuators on the upper channel until it is also centered on the same peak as the lower channel.

7. With both channels exactly centered on the peak, adjust the channel width on the upper channel until it counts at the same rate as the lower channe 1. 


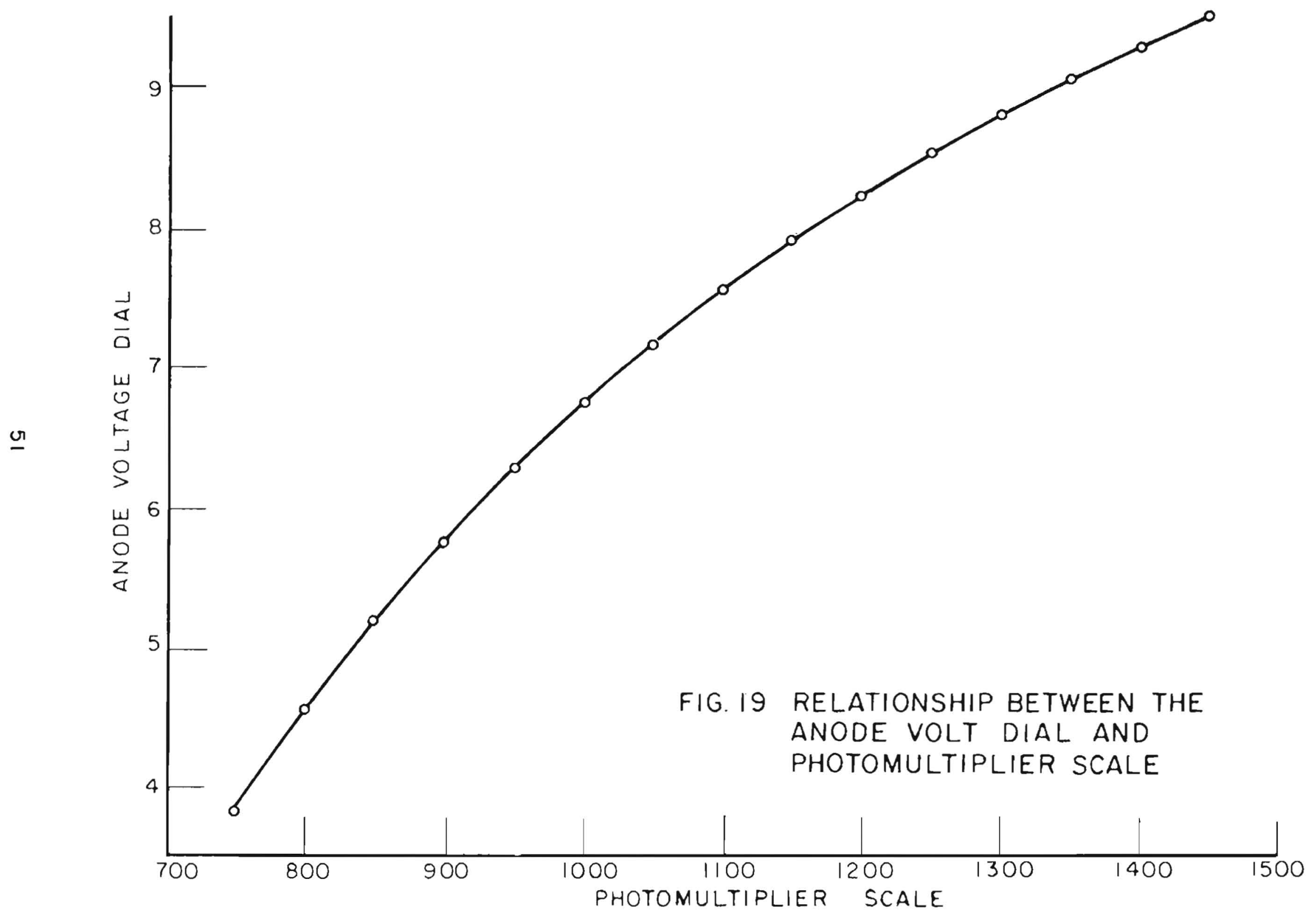




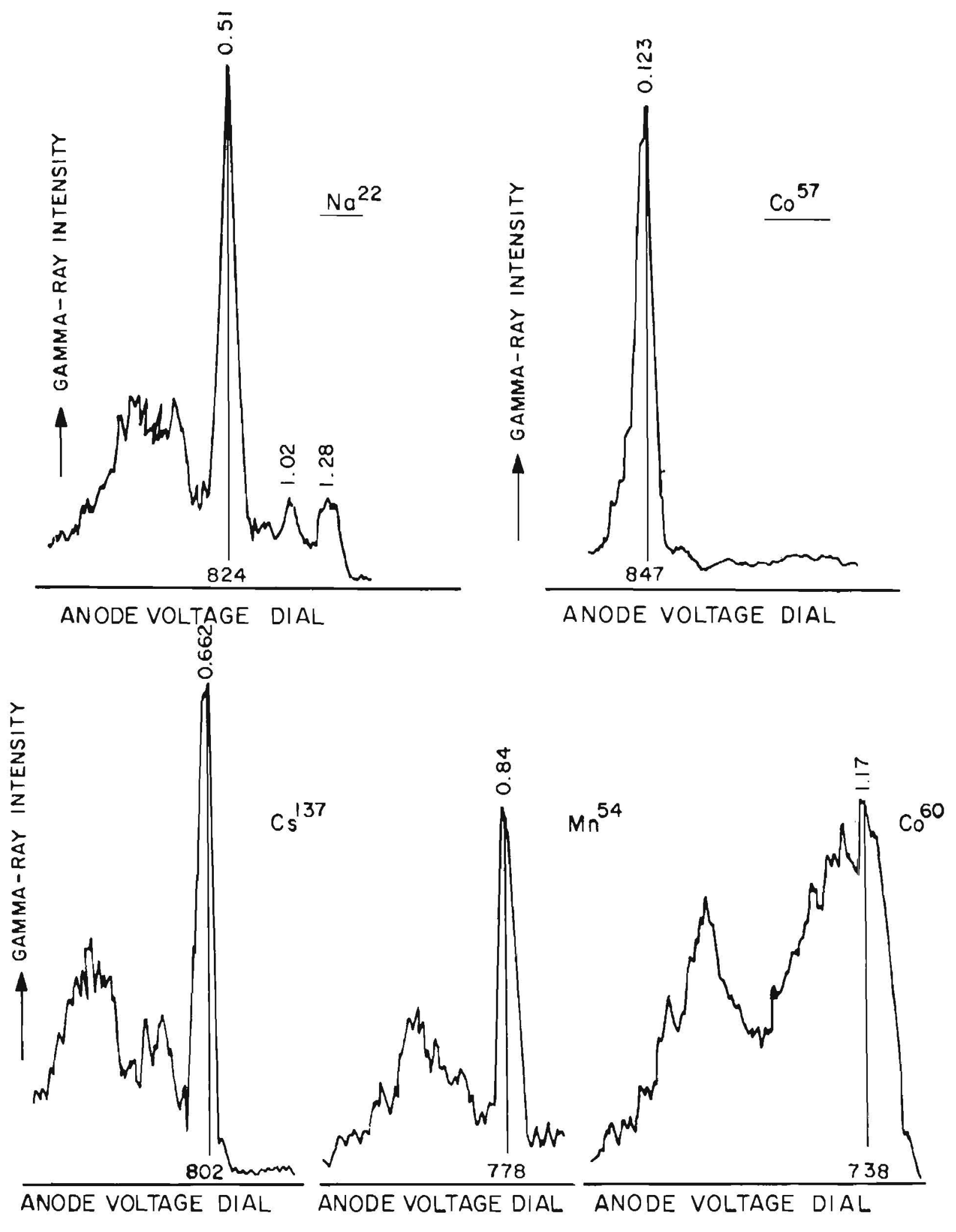

FIG. 20 GAMMA-RAY SPECTRA FOR STANDARDS 


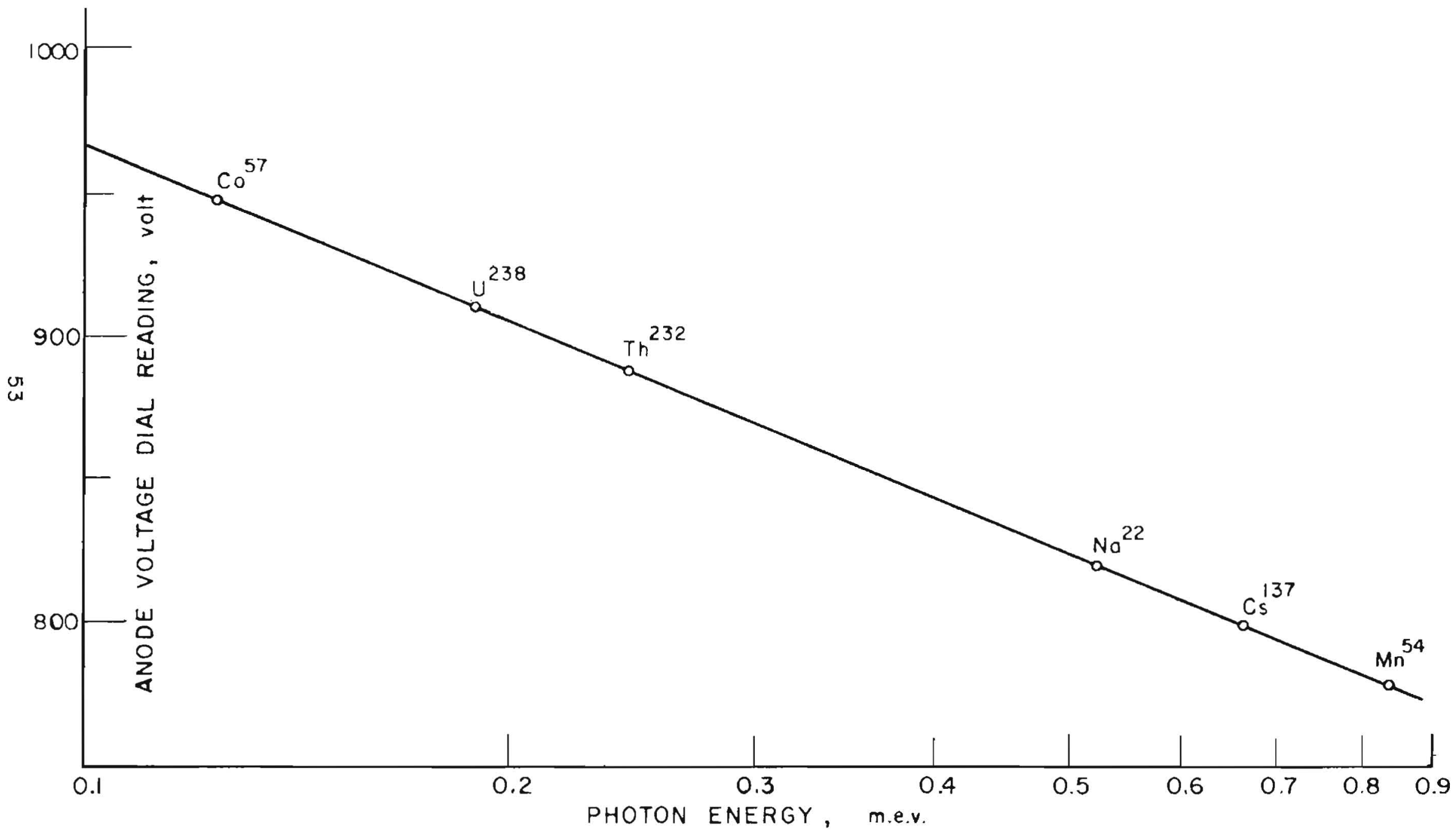

FIG. 2 I RELATIONSHIP BETWEEN THE ENERGY OF THE PHOTON PEAK AND THE ANODE DIAL READING AT WHICH THE PEAK APPEARS 


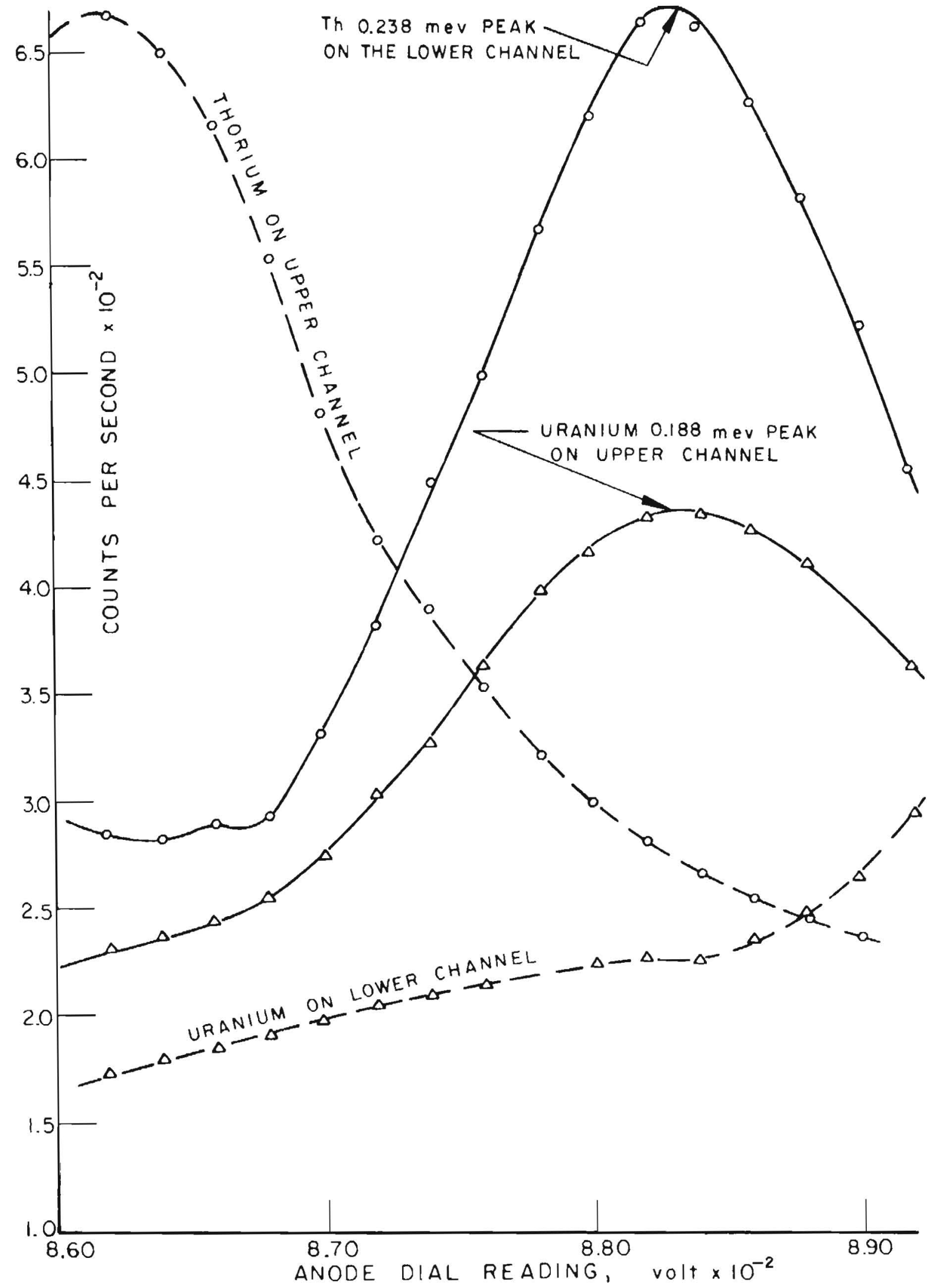

FIG. 22 Th AND Ur PEAKS COUNTING AT

THE SAME $\underset{54}{D I}$ IAL READING 
8. Place a thorium sample in the machine and find the voltage dial setting at which the lower channel is centered on the 0.238 mev. peak.

9. Leave the voltage dial alone and place an equilibrium uranium sample in the machine. Center the upper channel on the 0.188 mev. peak by means of the attenuators.

10. Check the upper and lower channels to be sure that they both reach a maximum peak count on the same voltage dial setting (Fig. 22). Any discrepancies are corrected by means of the channel calibration dials.

11. The channel counts and ratios are corrected with the assays by means of standard ores. 


\section{APPENDIX III}

\section{CORRBCTION FOR SAMPLE SIZE}

When the thickness of the sample is great, the photopeaks are swamped by Compton-scattered radiation from within the source. It was found that for a sample weight of more than 10 grams, correction should be made by introducing a correction factor $C$ which was obtained as follows:

1. Increasing weights of heavy minerals (from the same sand sample) were assayed and counted (Table 1 ).

The correction factor $C=$ maximum counts per gram weight of sample

$$
=\frac{C_{m}}{C} \text { counts per gram weight of sample was }
$$

plotted against the weight of the sample (Fig. 23).

2. A weight of 11 milligram thorium oxide (THO) was added to increasing weights of heavy minerals from the same sample used in( 1 ), assayed and counted on both channels. The net counting due to the addition of thorium oxide (THO) to the heavy minerals was plotted against the weight of heavy minerals (Fig. 24).

3. The net counting from 11 milligram thorium oxide (2HO) when assayed without the addition of any heavy minerals was recorded.

4. For step 2 above, the correction coefficient $C$ was calculated for different weights of the heavy minerals and was found to check we 11 with that of Fig. 23. For this reason, the correction coefficients from Fig. 23 were used in correcting counts for samples having a weight of more than 10 grams. 


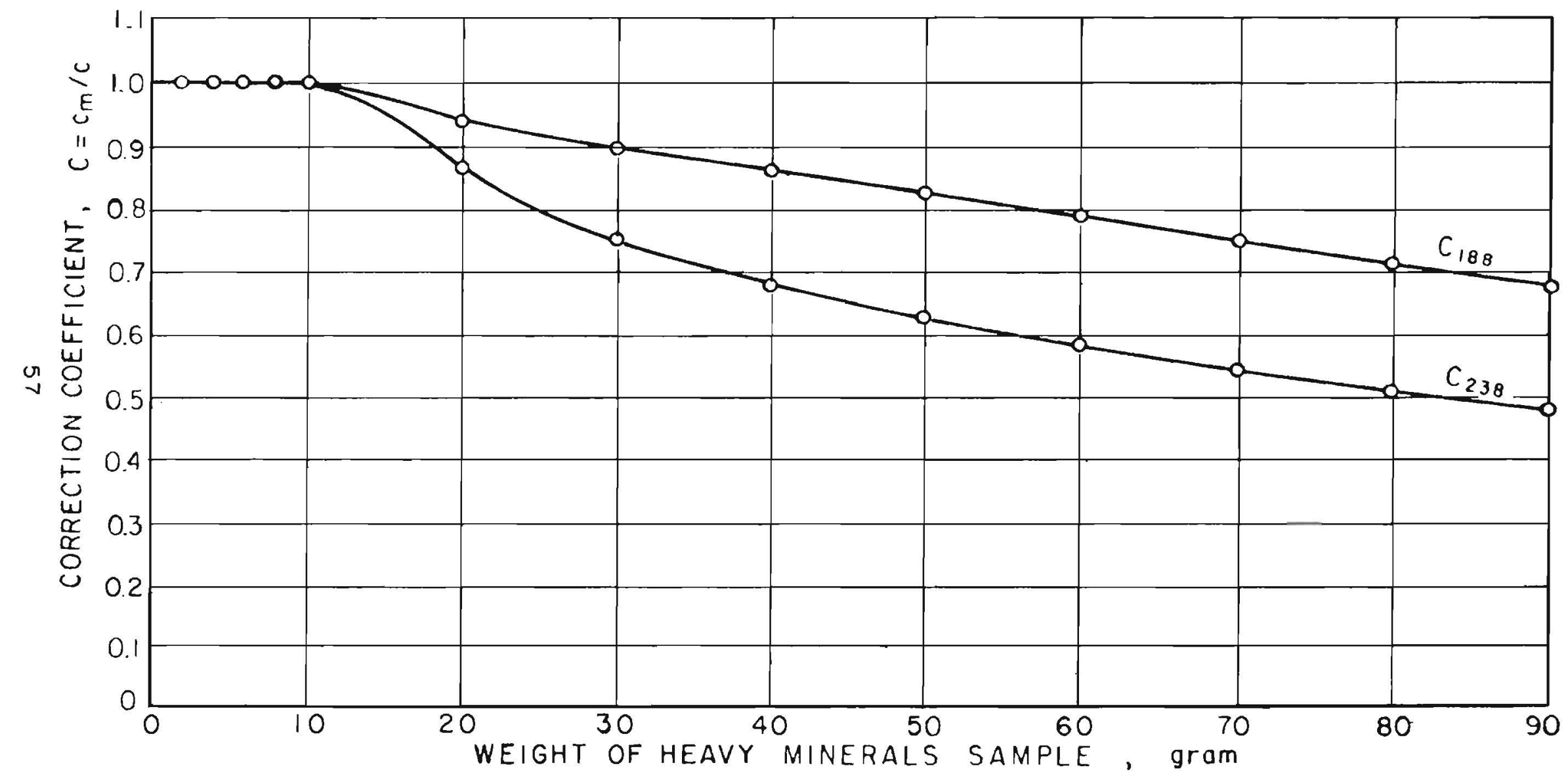

FIG. 23 CORRECTION COEFFICIENT DUE TO SAMPLE SIZE 


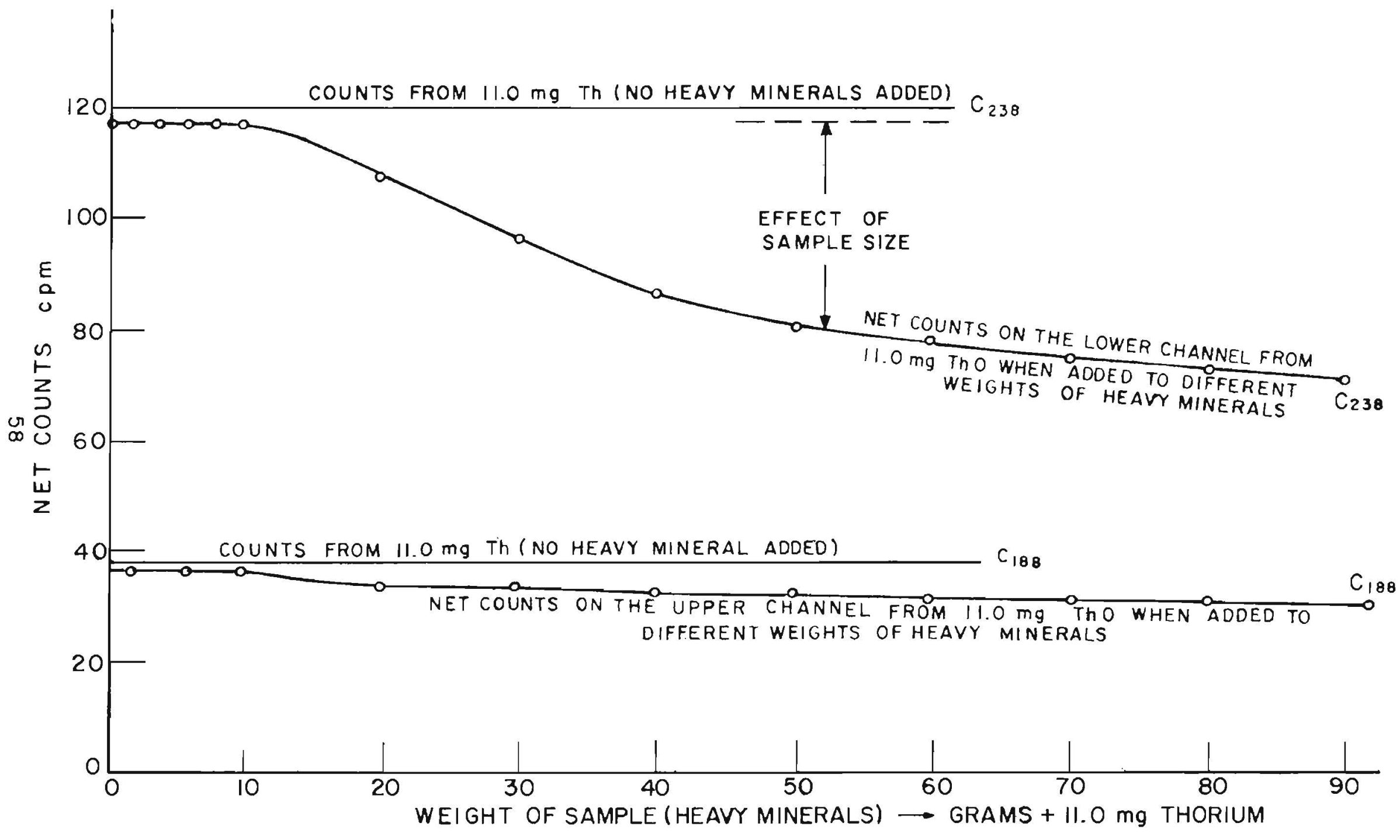

FIG. 24 EFFECT OF SAMPLE SIZE ON COUNTING RATE 
TABLE 1 CORRECTION COEFFICIENT C

\begin{tabular}{|c|c|c|c|c|c|c|}
\hline $\begin{array}{l}\text { Wt. of } \\
\text { heavies } \\
\text { gm. }\end{array}$ & $\begin{array}{c}\text { CPM } \\
\text { at } \\
0.238 \mathrm{mev} \text {. }\end{array}$ & $\begin{array}{c}\text { CPM } \\
\text { at } \\
0.188 \mathrm{mev} .\end{array}$ & $\begin{array}{c}\text { CPM } \\
\text { at } \\
0.238 \mathrm{mev} \text {. } \\
\end{array}$ & $\begin{array}{c}\text { CPM/gm . } \\
\text { at } \\
0.188 \mathrm{mev} .\end{array}$ & $\begin{array}{c}\mathrm{C} / \mathrm{Cm} \\
\text { at } \\
0.238 \mathrm{mev} .\end{array}$ & $\begin{array}{c}\mathrm{C} / \mathrm{Cm} \\
\text { at } \\
0.188 \mathrm{mev} \\
\end{array}$ \\
\hline 3 & 1.65 & 0.90 & 0.55 & 0.30 & -- & 1.00 \\
\hline 4 & 2.50 & 1.20 & 0.62 & 0.30 & -- & 1.00 \\
\hline 5 & 3.20 & 1.50 & 0.64 & 0.30 & 1.00 & 1.00 \\
\hline 6 & 3.90 & 1.85 & 0.65 & 0.31 & 1.00 & 1.00 \\
\hline 7 & 4.55 & 2.10 & 0.65 & 0.30 & 1.00 & 1.00 \\
\hline 8 & 5.15 & 2.40 & 0.65 & 0.30 & 1.00 & 1.00 \\
\hline 9 & 5.95 & 2.60 & 0.65 & 0.29 & 1.00 & 1.00 \\
\hline 10 & 6.50 & 2.95 & 0.65 & 0.30 & 1.00 & 1.00 \\
\hline 12 & 7.50 & 3.50 & 0.63 & 0.29 & 0.98 & 0.97 \\
\hline 14 & 8.50 & 4.00 & 0.61 & 0.29 & 0.94 & 0.96 \\
\hline 16 & 9.50 & 4.80 & 0.59 & 0.30 & 0.91 & 0.95 \\
\hline 18 & 10.40 & 5.15 & 0.58 & 0.28 & 0.89 & 0.95 \\
\hline 20 & 11.20 & 5.60 & 0.56 & 0.28 & 0.86 & 0.93 \\
\hline 25 & 13.00 & 7.00 & 0.52 & 0.28 & 0.80 & 0.93 \\
\hline 30 & 14.80 & 8.10 & 0.49 & 0.27 & 0.75 & 0.90 \\
\hline 35 & 16.30 & 9.45 & 0.46 & 0.27 & 0.71 & 0.90 \\
\hline 40 & 17.80 & 10.50 & 0.44 & 0.26 & 0.68 & 0.88 \\
\hline 50 & 20.50 & 12.35 & 0.41 & 0.25 & 0.63 & 0.82 \\
\hline 60 & 23.00 & 14.10 & 0.38 & 0.23 & 0.59 & 0.78 \\
\hline 70 & 25.00 & 1.5 .55 & 0.36 & 0.22 & 0.55 & 0.74 \\
\hline 80 & 26.85 & 1.7 .00 & 0.33 & 0.21 & 0.51 & 0.70 \\
\hline
\end{tabular}


APPENDIX IV - EXPERIMENTAL RESULTS

A - 1 Results of the study of the direction of ittoral drift

Table 1

\begin{tabular}{|c|c|c|c|c|c|c|}
\hline \multirow{3}{*}{$\begin{array}{c}\frac{1}{\text { Sample }} \\
\text { No. } \\
\end{array}$} & \multirow{3}{*}{$\begin{array}{c}\frac{2}{\text { Surface }} \\
\text { or } \\
\text { Deep }\end{array}$} & 3 & 4 & 5 & 6 & 7 \\
\hline & & \multirow[t]{2}{*}{ Location } & \multirow{2}{*}{$\begin{array}{l}\text { Size } \\
\text { fraction } \\
\text { anaiyzed }\end{array}$} & \multirow{2}{*}{$\begin{array}{l}\text { Weight of } \\
\text { heavies in } \\
\text { size fraction }\end{array}$} & \multicolumn{2}{|c|}{$\begin{array}{l}\text { Correction } \\
\text { Coefficient }\end{array}$} \\
\hline & & & & & $\mathrm{C}_{1}$ & $\mathrm{C}_{2}$ \\
\hline 1 & $\mathrm{SD}$ & Russian Gulch & 1 & 2.301 & 1.000 & 1.000 \\
\hline 2 & $\mathrm{~S}$ & Mouth, R. Gulch & 1 & 1.100 & 1.000 & 1.000 \\
\hline 2 & $\mathrm{D}$ & & 1 & 1.390 & 1.000 & 1.000 \\
\hline $3+4$ & $\mathrm{~S}$ & North R. R。 & 1 & 4.514 & 1.000 & 1.000 \\
\hline 4 & $\mathrm{D}$ & " " " " & 1 & 2.230 & 1.000 & 1.000 \\
\hline 5 & $\mathrm{~S}$ & " " " " & 1 & 7.319 & 1.000 & 1.000 \\
\hline 6 & $\mathrm{~S}$ & South R. R. & 1 & 10.676 & 0.995 & 0.992 \\
\hline 7 & $\mathrm{~S}$ & South Goat Rock & 1 & 6.573 & 1.000 & 1.000 \\
\hline 8 & $\mathrm{~S}$ & Russian River & 1 & 0.465 & 1.000 & 1.000 \\
\hline 8 & D & Russian River & 1 & 2.717 & 1.000 & 1.000 \\
\hline 9 & $\mathrm{~S}$ & Russian River & 1 & 3.925 & 1.000 & 1.000 \\
\hline 10 & SD & Austin Creek & 1 & 3.708 & 1.000 & 1.000 \\
\hline 11 & $\mathrm{D}$ & Russian River & 1 & 1.038 & 1.000 & 1.000 \\
\hline 11 & $\mathrm{~S}$ & Russian River & 1 & 0.304 & 1.000 & 1.000 \\
\hline 12 & SD & Shell Beach & 1 & 0.058 & 1.000 & 1.000 \\
\hline 13 & $\mathrm{~S}$ & Wright Beach & 1 & 2.927 & 1.000 & 1.000 \\
\hline 13 & $\mathrm{D}$ & Wright Beach & 1 & 2.076 & 1.000 & 1.000 \\
\hline 14 & $\mathrm{~S}$ & Gleason Beach & 1 & 4.493 & 1.000 & 1.000 \\
\hline 14 & D & Gleason Beach & 1 & 2.806 & 1.000 & 1.000 \\
\hline 15 & $\mathrm{~S}$ & Salmon Creek & 1 & 5.611 & 1.000 & 1.000 \\
\hline & & Beach & & & & \\
\hline 15 & $\mathrm{D}$ & $"$ & 1 & 2.883 & 1.000 & 1.000 \\
\hline 16 & $\mathrm{~S}$ & $"$ & 1 & 1.352 & 1.000 & 1.000 \\
\hline 16 & D & " & 1 & 0.832 & 1.000 & 1.000 \\
\hline 17 & $\mathrm{~S}$ & Doran Beach & 1 & 3.395 & 1.000 & 1.000 \\
\hline 17 & D & Doran Beach & 1 & 3.686 & 1.000 & 1.000 \\
\hline 18 & $S$ & Doran Beach & 1 & 3.689 & 1.000 & 1.000 \\
\hline 18 & $\mathrm{D}$ & Doran Beach & 1 & 3.079 & 1.000 & 1.000 \\
\hline 19 & $\mathrm{~S}$ & Doran Beach & 1 & 3.008 & 1.000 & 1.000 \\
\hline 19 & D & Doran Beach & 1 & 4.942 & 1.000 & 1.000 \\
\hline 20 & $\mathrm{~S}$ & Dillon Beach & 1 & 3.267 & 1.000 & 1.000 \\
\hline 20 & $\mathrm{D}$ & Dillon Beach & 1 & 1.985 & 1.000 & 1.000 \\
\hline 21 & $\mathrm{~S}$ & Dillon Beach & 1 & 4.114 & 1.000 & 1.000 \\
\hline 21 & $\mathrm{D}$ & Dilion Beach & 1 & 4.960 & 1.000 & 1.000 \\
\hline
\end{tabular}


Table 1 (contd.)

\begin{tabular}{|c|c|c|c|c|c|c|}
\hline \multirow{3}{*}{$\frac{1}{\text { Sample }}$} & \multirow{3}{*}{$\begin{array}{l}\frac{2}{\text { Surface }} \\
\text { or } \\
\text { Deep }\end{array}$} & 3 & 4 & 5 & 6 & 7 \\
\hline & & \multirow[t]{2}{*}{ Location } & \multirow{2}{*}{$\begin{array}{l}\text { Size } \\
\text { fraction } \\
\text { analyzed }\end{array}$} & \multirow{2}{*}{$\begin{array}{l}\text { Weight of } \\
\text { heavieg in } \\
\text { size fraction } \\
\mathrm{gm}\end{array}$} & \multicolumn{2}{|c|}{$\begin{array}{l}\text { Correction } \\
\text { Coefficient }\end{array}$} \\
\hline & & & & & $\mathrm{C}_{1}$ & $\mathrm{C}_{2}$ \\
\hline 22 & $\mathrm{~S}$ & McClures Beach & 1 & 8.370 & 1.000 & 1.000 \\
\hline 22 & $\mathrm{D}$ & McClures Beach & 1 & 8.090 & 1.000 & 1.000 \\
\hline 23 & $\mathrm{~S}$ & Pt. Reyes Beach & 3 & 2.035 & 1.000 & 1.000 \\
\hline 24 & $\mathrm{~S}$ & Pt. Reyes Beach & 3 & 2.035 & 1.000 & 1.000 \\
\hline 25 & $\mathrm{~S}$ & Pt. Reyes Beach & 3 & 7.157 & 1.000 & 1.000 \\
\hline 26 & $\mathrm{SD}$ & Pt. Reyes Beach & 3 & 848 & 1.000 & 1.000 \\
\hline 27 & $\mathrm{~S}$ & Drakes Beach & 1 & 5.327 & 1.000 & 1.000 \\
\hline 27 & $\mathrm{D}$ & Drakes Beach & 1 & 8.041 & 1.000 & 1.000 \\
\hline 28 & $\mathrm{~S}$ & Drakes Beach & 1 & 71.006 & 0.740 & 0.550 \\
\hline 28 & $\mathrm{D}$ & Drakes Beach & 1 & 37.906 & .872 & .695 \\
\hline 29 & $\mathrm{~S}$ & Drakes Beach & 1 & 19.406 & .945 & .865 \\
\hline 29 & $\mathrm{D}$ & Drakes Beach & 1 & 20.836 & .940 & .850 \\
\hline 30 & $\mathrm{~S}$ & Drakes Beach & 1 & 14.133 & .970 & .940 \\
\hline 30 & $\mathrm{D}$ & Drakes Beach & 1 & 14.908 & .968 & .927 \\
\hline 31 & $\mathrm{~S}$ & Drakes Bay & 1 & 1.255 & 1.000 & 1.000 \\
\hline 31 & $\mathrm{D}$ & Drakes Bay & 1 & 1.484 & 1.000 & 1.000 \\
\hline 32 & $\mathrm{~S}$ & Drakes Bay & 1 & .834 & 1.000 & 1.000 \\
\hline 32 & $\mathrm{D}$ & Drakes Bay & 1 & .762 & 1.000 & 1.000 \\
\hline 33 & $\mathrm{~S}$ & Bolinas Beach & 1 & 2.264 & 1.000 & 1.000 \\
\hline 33 & $\mathrm{D}$ & Bolinas Beach & 1 & 1.764 & 1.000 & 1.000 \\
\hline 34 & $\mathrm{~S}$ & Bolinas Beach & 1 & 1.961 & 1.000 & 1.000 \\
\hline 34 & $\mathrm{D}$ & Bolinas Beach & 1 & 2.742 & 1.000 & 1.000 \\
\hline $35+36+37$ & $\mathrm{~S}$ & Stinson Beach & 1 & .699 & 1.000 & 1.000 \\
\hline 35 & D & Stinson Beach & 1 & 1.008 & 1.000 & 1.000 \\
\hline 36 & $\mathrm{D}$ & Stinson Beach & 1 & .332 & 1.000 & 1.000 \\
\hline 37 & $\mathrm{D}$ & Stinson Beach & 1 & .471 & 1.000 & 1.000 \\
\hline 38 & $\mathrm{~S}$ & Ocean Beach & 2 & 21.252 & 0.940 & 0.845 \\
\hline 38 & $\mathrm{~S}$ & Ocean Beach & 1 & 20.585 & 0.942 & 0.851 \\
\hline 39 & $\mathrm{~S}$ & Ocean Beach & 2 & 31.193 & 0.900 & 0.742 \\
\hline 39 & $\mathrm{~S}$ & Ocean Beach & 1 & 31.453 & 0.900 & 0.740 \\
\hline 40 & $\mathrm{~S}$ & Ocean Beach & 2 & 10.963 & 0.995 & 0.990 \\
\hline 40 & $S$ & Ocean Beach & 1 & 5.418 & 1.000 & 1.000 \\
\hline 40 & $\mathrm{D}$ & Ocean Beach & 2 & 11.708 & 0.990 & 0.980 \\
\hline 40 & $\mathrm{D}$ & Ocean Beach & 1 & 8.012 & 1.000 & 1.000 \\
\hline 41 & $\mathrm{~S}$ & Ocean Beach & 2 & 9.643 & 1.000 & 1.000 \\
\hline
\end{tabular}


Table 1 (contd.)

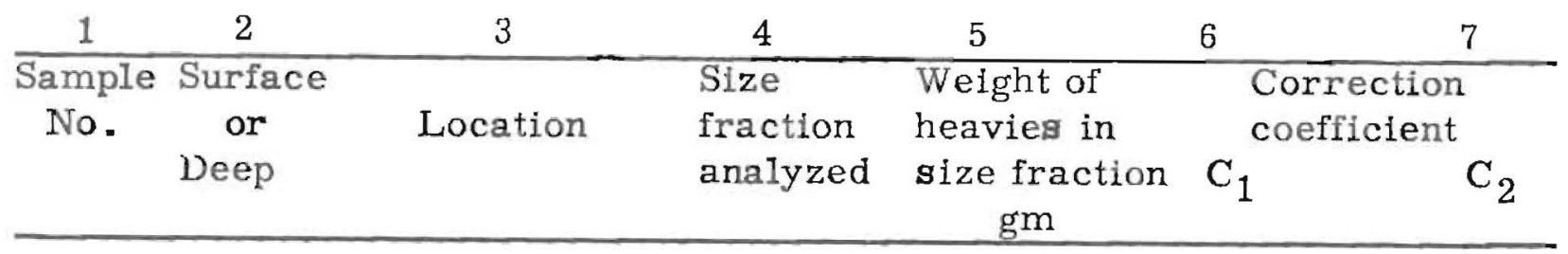

\begin{tabular}{|c|c|c|c|c|c|c|}
\hline 41 & $\mathrm{~S}$ & Ocean Beach & 1 & 9.373 & 1.000 & 1.000 \\
\hline 42 & $\mathrm{~S}$ & Ocean Beach & 2 & 6.982 & 1.000 & 1.000 \\
\hline 42 & $\mathrm{D}$ & Ocean Beach & 1 & 3.593 & 1.000 & 1.000 \\
\hline 43 & $\mathrm{~S}$ & Ocean Beach & 2 & 6.295 & 1.000 & 1.000 \\
\hline 43 & $\mathrm{~S}$ & Ocean Beach & 1 & 2.070 & 1.000 & 1.000 \\
\hline 44 & $\mathrm{~S}$ & Ocean Beach & 2 & 4.601 & 1.000 & 1.000 \\
\hline 44 & $\mathrm{~S}$ & Ocean Beach & 1 & 2.110 & 1.000 & 1.000 \\
\hline 44 & $\mathrm{D}$ & Ocean Beach & 2 & 5.804 & 1.000 & 1.000 \\
\hline 44 & $\mathrm{D}$ & Ocean Beach & 1 & 1.808 & 1.000 & 1.000 \\
\hline 45 & $\mathrm{~S}$ & Ocean Beach & 2 & 4.575 & 1.000 & 1.000 \\
\hline 45 & $\mathrm{~S}$ & Ocean Beach & 1 & 2.067 & 1.000 & 1.000 \\
\hline 45 & $\mathrm{D}$ & Ocean Beach & 2 & 7.938 & 1.000 & 1.000 \\
\hline 45 & $\mathrm{D}$ & Ocean Beach & 1 & 2.817 & 1.000 & 1.000 \\
\hline 46 & $\mathrm{~S}$ & Ocean Beach & 2 & 25.633 & 0.920 & 0.795 \\
\hline 46 & $\mathrm{~S}$ & Ocean Beach & 1 & 13.844 & 0.975 & 0.945 \\
\hline 47 & $\mathrm{~s}$ & Ocean Beach & 2 & 7.318 & 0.975 & 0.945 \\
\hline 47 & $\mathrm{~S}$ & Ocean Beach & 1 & 1.403 & 0.975 & 0.945 \\
\hline 47 & $\mathrm{D}$ & Ocean Beach & 2 & 4.546 & 0.975 & 0.945 \\
\hline 47 & $\mathrm{D}$ & Ocean Beach & 1 & 1.492 & 0.975 & 0.945 \\
\hline 48 & $\mathrm{~S}$ & Fleishbacker & 2 & 73.536 & 0.730 & 0.540 \\
\hline 48 & $\mathrm{~S}$ & Fleishhacker & 1 & 19.053 & 0.950 & 0.871 \\
\hline 48 & $\mathrm{D}$ & Fleishhacker & 2 & 38.802 & 0.870 & 0.690 \\
\hline 48 & $\mathrm{D}$ & Fleishhac ker & 1 & 13.840 & 0.975 & 0.945 \\
\hline 49 & $\mathrm{~S}$ & Daly City & 2 & 22.227 & 0.935 & 0.835 \\
\hline 49 & $\mathrm{~S}$ & Daly City & 1 & 8.922 & 1.000 & 1.000 \\
\hline 49 & $\mathrm{D}$ & Daly City & 2 & 20.307 & 0.940 & 0.855 \\
\hline 49 & $\mathrm{D}$ & Daly City & 1 & 8.511 & 0.950 & 0.875 \\
\hline 50 & $\mathrm{~S}$ & Daly City & 2 & 10.000 & 1.000 & 1.000 \\
\hline 50 & $\mathrm{~S}$ & Daly City & 1 & 4.394 & 1.000 & 1.000 \\
\hline 51 & $\mathrm{~S}$ & N. Mussel Rock & 1 & 11.334 & 0.992 & 0.985 \\
\hline 52 & $\mathrm{~S}$ & N. Mussel Rock & 1 & 31.311 & 0.900 & 0.740 \\
\hline 53 & $\mathrm{~S}$ & Sharp Park & 2 & 3.652 & 1.000 & 1.000 \\
\hline 53 & $S$ & Sharp Park & 1 & 3.869 & 1.000 & 1.000 \\
\hline 53 & $\mathrm{D}$ & Sharp Park & 2 & 7.740 & 1.000 & 1.000 \\
\hline 53 & $\mathrm{D}$ & Sharp Park & 1 & 8.010 & 1.000 & 1.000 \\
\hline 54 & $\mathrm{~S}$ & Sharp Park & 2 & 13.840 & 0.975 & 0.945 \\
\hline 54 & $\mathrm{~S}$ & Sharp Park & 1 & 14.131 & 0.972 & 0.940 \\
\hline 55 & $\mathrm{~S}$ & Sharp Park & 2 & 10.508 & 0.995 & 0.995 \\
\hline 55 & $\mathrm{~S}$ & Sharp Park & 1 & 1.077 & 1.000 & 1.000 \\
\hline
\end{tabular}


Table 1 (contd.)

\begin{tabular}{ccccccc}
1 & 2 & 3 & 4 & 5 & 6 & 7 \\
\hline $\begin{array}{c}\text { Sample } \\
\text { No. }\end{array}$ & Surface & or & Location & Size & Weight of & Correction \\
& Deep & & analyzed & heavies in & size fraction \\
& & & $\mathrm{C}_{1}$ & $\mathrm{C}_{2}$ \\
\hline
\end{tabular}

$\begin{array}{llllrrr}56 & \text { S } & \text { Mori Pt. } & 2 & 12.722 & 0.982 & 0.965 \\ 56 & \text { S } & \text { Mori Pt. } & 1 & 1.188 & 1.000 & 1.000 \\ 57 & \text { S } & \text { Rockaway Beach } & 2 & 28.038 & 0.910 & 0.770 \\ 57 & \text { S } & \text { Rockaway Beach } & 1 & 4.548 & 1.000 & 1.000 \\ 57 & \text { D } & \text { Rockaway Beach } & 2 & 13.747 & 0.975 & 0.945 \\ 57 & \text { D } & \text { Rockaway Beach } & 1 & 1.524 & 1.000 & 1.000 \\ 58 & \text { S } & \text { San Pedro } & 2 & 50.638 & 0.820 & 0.630 \\ 58 & \text { S } & \text { San Pedro } & 1 & 25.275 & 0.925 & 0.800 \\ 59 & \text { S } & \text { Shelter Cove } & 3 & 0.687 & 1.000 & 1.000\end{array}$


Table 1 (contd.)

\begin{tabular}{|c|c|c|c|c|}
\hline \multirow{3}{*}{$\begin{array}{c}\frac{1}{\text { Sample }} \\
\text { No. }\end{array}$} & 8 & 9 & 10 & 11 \\
\hline & \multicolumn{2}{|c|}{ Net counting rate cpm. } & \multicolumn{2}{|c|}{ Corrected counting rate cpm. } \\
\hline & $\begin{array}{c}0.188 \mathrm{mev} . \\
\mathrm{R}_{1}\end{array}$ & $\begin{array}{c}0.238 \mathrm{mev} . \\
\mathrm{R}_{2}\end{array}$ & $\begin{array}{l}0.188 \text { mev. } \\
\mathrm{R}_{1}=8 / 6\end{array}$ & $\begin{array}{l}0.238 \mathrm{mev} . \\
\mathrm{R}_{2}=9 / 7\end{array}$ \\
\hline 1 & 308 & 458 & 308 & 458 \\
\hline 2 & 216 & 263 & 216 & 263 \\
\hline 2 & 254 & 338 & 254 & 338 \\
\hline $3+4$ & 431 & 890 & 431 & 890 \\
\hline 4 & 218 & 464 & 218 & 464 \\
\hline 5 & 840 & 1.504 & 840 & 1.504 \\
\hline 6 & 1.086 & 1.932 & 1.091 & 1.947 \\
\hline 7 & 613 & 786 & 613 & 786 \\
\hline 8 & 331 & 192 & 331 & 192 \\
\hline 8 & 418 & 526 & 418 & 526 \\
\hline 9 & 355 & 734 & 355 & 734 \\
\hline 10 & 000 & 257 & 000 & 257 \\
\hline 11 & 290 & 295 & 290 & 295 \\
\hline 11 & 391 & 203 & 391 & 203 \\
\hline 12 & 000 & 000 & 000 & 000 \\
\hline 13 & 407 & 790 & 407 & 790 \\
\hline 13 & 000 & 350 & 000 & 350 \\
\hline 14 & 471 & 979 & 471 & 979 \\
\hline 14 & 311 & 547 & 311 & 547 \\
\hline 15 & 1.054 & 1.320 & 1.054 & 1.320 \\
\hline 15 & 983 & 794 & 983 & 794 \\
\hline 16 & 541 & 411 & 541 & 411 \\
\hline 16 & 493 & 307 & 493 & 307 \\
\hline 17 & 705 & 562 & 705 & 562 \\
\hline 17 & 558 & 1.007 & 558 & 1.007 \\
\hline 18 & 639 & 1.229 & 639 & 1.229 \\
\hline 18 & 683 & 1.124 & 683 & 1.124 \\
\hline 19 & 602 & 1.196 & 602 & 1.196 \\
\hline 19 & 950 & 1.482 & 950 & 1.482 \\
\hline 20 & 580 & 965 & 580 & 965 \\
\hline 20 & 691 & 1.006 & 691 & 1.006 \\
\hline 21 & 691 & 1.433 & 691 & 1.433 \\
\hline 21 & 1.216 & 2.427 & 1.216 & 2.427 \\
\hline
\end{tabular}


Table 1 (contd.)

\begin{tabular}{|c|c|c|c|c|}
\hline \multirow{3}{*}{$\begin{array}{c}\frac{1}{\text { Sample }} \\
\text { No. }\end{array}$} & 8 & 9 & 10 & 11 \\
\hline & \multicolumn{2}{|c|}{ Net counting rate cpm. } & \multicolumn{2}{|c|}{ Corrected counting rate $\mathrm{cpm}$. } \\
\hline & $\begin{array}{l}0.188 \mathrm{mev} \\
\mathrm{R}_{1}\end{array}$ & $\begin{array}{c}0.238 \mathrm{mev} . \\
\mathrm{R}_{2} \\
\end{array}$ & $\begin{array}{l}0.188 \mathrm{mev} . \\
\mathrm{R}_{\mathrm{I}}=8 / 6\end{array}$ & $\begin{array}{l}0.238 \text { mev. } \\
\mathrm{R}_{2}=9 / 7\end{array}$ \\
\hline 22 & 2.995 & 6.039 & 2.995 & 6.039 \\
\hline 22 & 3.101 & 6.123 & 3.101 & 6.123 \\
\hline 23 & .605 & .750 & .605 & .750 \\
\hline 24 & .605 & .750 & .605 & .750 \\
\hline 25 & .928 & 1.438 & .928 & 1.438 \\
\hline 26 & .177 & .108 & .177 & .108 \\
\hline 27 & 3.528 & 4.744 & 3.528 & 4.744 \\
\hline 27 & 8.564 & 12.699 & 8.564 & 12.699 \\
\hline 28 & 82.671 & 104.202 & 117.176 & 187.640 \\
\hline 28 & 45.828 & 60.682 & 52.555 & 87.312 \\
\hline 29 & 5.077 & 7.701 & 5.372 & 8.903 \\
\hline 29 & 5.644 & 11.708 & 6.004 & 13.774 \\
\hline 30 & 2.680 & 5.015 & 2.763 & 5.335 \\
\hline 30 & 4.553 & 7.737 & 4.703 & 8.346 \\
\hline 31 & .591 & .448 & .591 & .448 \\
\hline 31 & .832 & .745 & .832 & .745 \\
\hline 32 & .315 & .232 & .315 & .232 \\
\hline 32 & .318 & .254 & .318 & .254 \\
\hline 33 & 3.434 & 4.292 & 3.434 & 4.292 \\
\hline 33 & 2.314 & 3.092 & 2.314 & 3.092 \\
\hline 34 & 2.408 & 2.610 & 2.408 & 2.610 \\
\hline 34 & 2.693 & 3.795 & 2.693 & 3.795 \\
\hline $35+36+37$ & .634 & .430 & .634 & .430 \\
\hline 35 & .355 & .409 & .355 & .409 \\
\hline 36 & .514 & .239 & .514 & .239 \\
\hline 37 & .493 & .233 & .493 & .233 \\
\hline 38 & 2.093 & 3.327 & 2.227 & 3.938 \\
\hline 38 & 3.483 & 6.122 & 3.797 & 7.194 \\
\hline 39 & 1.823 & 3.924 & 2.026 & 5.288 \\
\hline 39 & 3.102 & 5.532 & 3.447 & 7.476 \\
\hline 40 & 1.656 & 2.916 & 1.665 & 2.945 \\
\hline 40 & 1.902 & 3.472 & 1.902 & 3.472 \\
\hline 40 & 1.159 & 2.241 & 1.212 & 2.287 \\
\hline 40 & 1.892 & 3.622 & 1.892 & 3.622 \\
\hline 41 & 1.066 & 2.335 & 1.066 & 2.335 \\
\hline 41 & 1.102 & 2.265 & 1.102 & 2.265 \\
\hline 42 & 1.170 & 1.913 & 1.170 & 1.913 \\
\hline 42 & 1.023 & 1.635 & 1.023 & 1.635 \\
\hline 43 & 0.083 & 1.515 & 0.832 & 1.515 \\
\hline 43 & 0.885 & 1.422 & 0.885 & 1.422 \\
\hline 44 & 0.716 & 1.299 & 0.716 & 1.299 \\
\hline
\end{tabular}


Table 1 (continued)

\begin{tabular}{|c|c|c|c|c|}
\hline 1 & 8 & 9 & 10 & 11 \\
\hline \multirow{2}{*}{$\begin{array}{c}\text { Sample } \\
\text { No. }\end{array}$} & \multicolumn{2}{|c|}{ Net counting rate cpm. } & \multicolumn{2}{|c|}{ Corrected counting rate $\mathrm{cpm}$. } \\
\hline & $\begin{array}{c}0.188 \mathrm{mev} \\
\mathrm{R}_{1}\end{array}$ & $\begin{array}{c}0.238 \mathrm{mev} . \\
\mathrm{R}_{2}\end{array}$ & $\begin{array}{l}\quad 0.188 \mathrm{mev} . \\
\mathrm{R}_{1}=8 / 6\end{array}$ & $\begin{array}{l}0.238 \text { mev. } \\
\mathrm{R}_{2}=9 / 7\end{array}$ \\
\hline 44 & 0.592 & 1.562 & 0.592 & 1.562 \\
\hline 44 & 0.754 & 1.085 & 0.754 & 1.085 \\
\hline 44 & 0.622 & 1.107 & 0.622 & 1.107 \\
\hline 45 & 1.015 & 1.831 & 1.015 & 1.831 \\
\hline 45 & 1.524 & 2.363 & 1.524 & 2.363 \\
\hline 45 & 1.734 & 2.825 & 1.734 & 2.825 \\
\hline 45 & 1.852 & 2.580 & 1.852 & 2.580 \\
\hline 46 & 4.114 & 6.837 & 4.472 & 8.597 \\
\hline 46 & 6.557 & 10.631 & 6.725 & 11.250 \\
\hline 47 & 1.202 & 2.335 & 1.202 & 2.355 \\
\hline 47 & 0.792 & 1.275 & 0.792 & 1.275 \\
\hline 47 & 1.223 & 2.564 & 1.223 & 2.564 \\
\hline 47 & 0.495 & 0.940 & 0.495 & 0.940 \\
\hline 48 & 11.750 & 20.320 & 16.096 & 37.630 \\
\hline 48 & 10.062 & 21,048 & 10.592 & 24.165 \\
\hline 48 & 7.541 & 13.593 & 8.668 & 19.700 \\
\hline 48 & 2.718 & 6.050 & 2.788 & 6.402 \\
\hline 49 & 2.047 & 4.648 & 2.189 & 5.566 \\
\hline 49 & 2.365 & 4.402 & 2.365 & 4.402 \\
\hline 49 & 2.818 & 5.854 & 2.998 & 6.847 \\
\hline 49 & 2.437 & 6.634 & 2.565 & 7.582 \\
\hline 50 & 0.906 & 2.192 & 0.906 & 2.192 \\
\hline 50 & 0.875 & 1.809 & 0.875 & 1.809 \\
\hline 51 & -- & $-\infty$ & -- & - \\
\hline 51 & 3.342 & 4.739 & 3.369 & 4.811 \\
\hline 52 & $-\infty$ & $-\infty$ & -- & $\ldots$ \\
\hline 52 & 8.800 & 11.413 & 9.781 & 15.420 \\
\hline 53 & 0.408 & 0.774 & 0.408 & 0.774 \\
\hline 53 & 0.511 & 1.183 & 0.511 & 1.183 \\
\hline 53 & 2.786 & 2.559 & 2.786 & 2.559 \\
\hline 53 & 2.913 & 3.476 & 2.913 & 3.476 \\
\hline 54 & 3.355 & 6.334 & 3.441 & 6.703 \\
\hline 54 & 8.499 & 14.686 & 8.744 & 15.624 \\
\hline 55 & 2.873 & 5.420 & 2.887 & 5.447 \\
\hline 55 & 0.787 & 1.272 & 0.787 & 1.272 \\
\hline 56 & 2.933 & 4.759 & 2.987 & 5.035 \\
\hline 56 & 0.650 & 1.158 & 0.650 & 1.158 \\
\hline 57 & 3.991 & 7.114 & 4.386 & 9.239 \\
\hline 57 & 1.679 & 3.312 & 1.679 & 3.312 \\
\hline 57 & 3.893 & 5.780 & 3.993 & 6.116 \\
\hline 57 & 0.865 & 1.593 & 0.865 & 1.593 \\
\hline 58 & 6.421 & 12.198 & 7.830 & 19.360 \\
\hline & & 66 & & \\
\hline
\end{tabular}


Table 1 (contd.)

\begin{tabular}{ccccc}
1 & 8 & 9 & 10 & 11 \\
\hline Sample & Net counting rate cpm. & Corrected counting rate cpm. \\
No. & $0.188 \mathrm{mev}$. & $0.238 \mathrm{mev}$. & $0.188 \mathrm{mev}$. & $\begin{array}{c}0.238 \mathrm{mev} \\
\end{array}$ \\
$\mathrm{R}_{1}$ & $\mathrm{R}_{2}$ & $\mathrm{R}_{1}=8 / 6$ & $\mathrm{R}_{2}=9 / 7$ \\
\hline 58 & 10.178 & 19.753 & 11.003 & 24.691 \\
59 & 1.167 & 2.637 & 1.167 & 2.637
\end{tabular}


Table 1 (continued)

\begin{tabular}{|c|c|c|c|c|c|}
\hline 1 & 12 & 13 & 14 & 15 & 16 \\
\hline $\begin{array}{c}\text { Sample } \\
\text { No. }\end{array}$ & $\begin{array}{c}2.832 \mathrm{R}_{2} \\
\mathrm{cpm},\end{array}$ & $\begin{array}{c}12-10 \\
\text { cpm. }\end{array}$ & $\begin{array}{l}Y \mathrm{cpm}= \\
13 / 2,446\end{array}$ & $\begin{array}{l}\text { Th. in mg. } \\
14 \times 0.09 \\
\end{array}$ & $\begin{array}{c}\text { Th. in } \mathrm{ppm} \\
15 / 5\end{array}$ \\
\hline 1 & 1.297 & 0.989 & 0.404 & 0.036 & 15.64 \\
\hline 2 & 0.745 & 0.529 & 0.216 & 0.019 & 17.27 \\
\hline 2 & 0.957 & 0.703 & 0.287 & 0.026 & 18.70 \\
\hline $3+4$ & 2.520 & 2.089 & 0.854 & 0.077 & 17.06 \\
\hline 4 & 1.778 & 1.560 & 0.638 & 0.057 & 25.56 \\
\hline 5 & 4.259 & 3.419 & 1.398 & 0.126 & 17.21 \\
\hline 6 & 5.514 & 4.423 & 1.808 & 0.163 & 15.27 \\
\hline 7 & 2.226 & 1.613 & 0.659 & 0.059 & 8.98 \\
\hline 8 & 0.544 & 0.213 & 0.087 & 0.008 & 17.20 \\
\hline 8 & 1.490 & 1.072 & 0.438 & 0.039 & 14.35 \\
\hline 9 & 2.079 & 1.724 & 0.705 & 0.063 & 16.05 \\
\hline 10 & 0.728 & 0.728 & 0.298 & 0.027 & 7.92 \\
\hline 11 & 0.835 & 0.545 & 0.223 & 0.020 & 19.27 \\
\hline 11 & 0.575 & 0.184 & 0.075 & 0.007 & 23.03 \\
\hline 12 & - & 0.000 & 0.000 & 0.000 & 00.00 \\
\hline 13 & 2.237 & 1.830 & 0.748 & 0.067 & 22.89 \\
\hline 13 & 0.991 & 0.991 & 0.405 & 0.036 & 17.34 \\
\hline 14 & 2.772 & 2.301 & 0.941 & 0.085 & 18.92 \\
\hline 14 & 1.549 & 1.238 & 0.506 & 0.045 & 16.04 \\
\hline 15 & 3.738 & 2.684 & 1.097 & 0.099 & 17.64 \\
\hline 15 & 2.248 & 1.265 & 0.517 & 0.046 & 15.95 \\
\hline 16 & 1.164 & 0.623 & 0.255 & 0.023 & 17.01 \\
\hline 16 & 0.869 & 0.376 & 0.154 & 0.014 & 16.83 \\
\hline 17 & 1.591 & 0.886 & 0.362 & 0.033 & 9.72 \\
\hline 17 & 2.852 & 2.294 & 0.938 & 0.084 & 22.79 \\
\hline 18 & 3.480 & 2.841 & 1.161 & 0.104 & 28.19 \\
\hline 18 & 3.183 & 2.500 & 1.022 & 0.092 & 29.88 \\
\hline 19 & 3.387 & 2.785 & 1.139 & 0.102 & 33.91 \\
\hline 19 & 4.197 & 3.247 & 1.327 & 0.119 & 24.08 \\
\hline 20 & 2.733 & 2.153 & 0.880 & 0.079 & 24.18 \\
\hline 20 & 2.849 & 2.158 & 0.882 & 0.079 & 39.79 \\
\hline 21 & 4.058 & 3.367 & 1.376 & 0.124 & 30.14 \\
\hline 21 & 6.873 & 5.657 & 2.313 & 0.208 & 41.93 \\
\hline 22 & 17.102 & 14.107 & 5.767 & 0.519 & 62.01 \\
\hline 22 & 17.340 & 14.239 & 5.821 & 0.524 & 64.77 \\
\hline 23 & 2.124 & 1.519 & 0.621 & 0.056 & 27.52 \\
\hline 24 & 2.124 & 1.519 & 0.621 & 0.056 & 27.52 \\
\hline 25 & 4.072 & 3.144 & 1.285 & 0.116 & 16.21 \\
\hline 26 & 0.309 & 0.132 & 0.054 & 0.005 & 5.90 \\
\hline 27 & 13.435 & 9.907 & 4.050 & 0.364 & 68.33 \\
\hline 27 & 35.963 & 27.396 & 11.200 & 1.008 & 125.36 \\
\hline 28 & 531.396 & 414.220 & 169.346 & 15.241 & 214.64 \\
\hline 23 & 247.267 & 194.712 & 79.604 & 7.164 & 188.99 \\
\hline 29 & 25.213 & 19.841 & 8.112 & 0.730 & 37.62 \\
\hline 29 & 39.008 & 33.004 & 13.493 & 1.214 & 58.26 \\
\hline
\end{tabular}


Table 1 (continued)

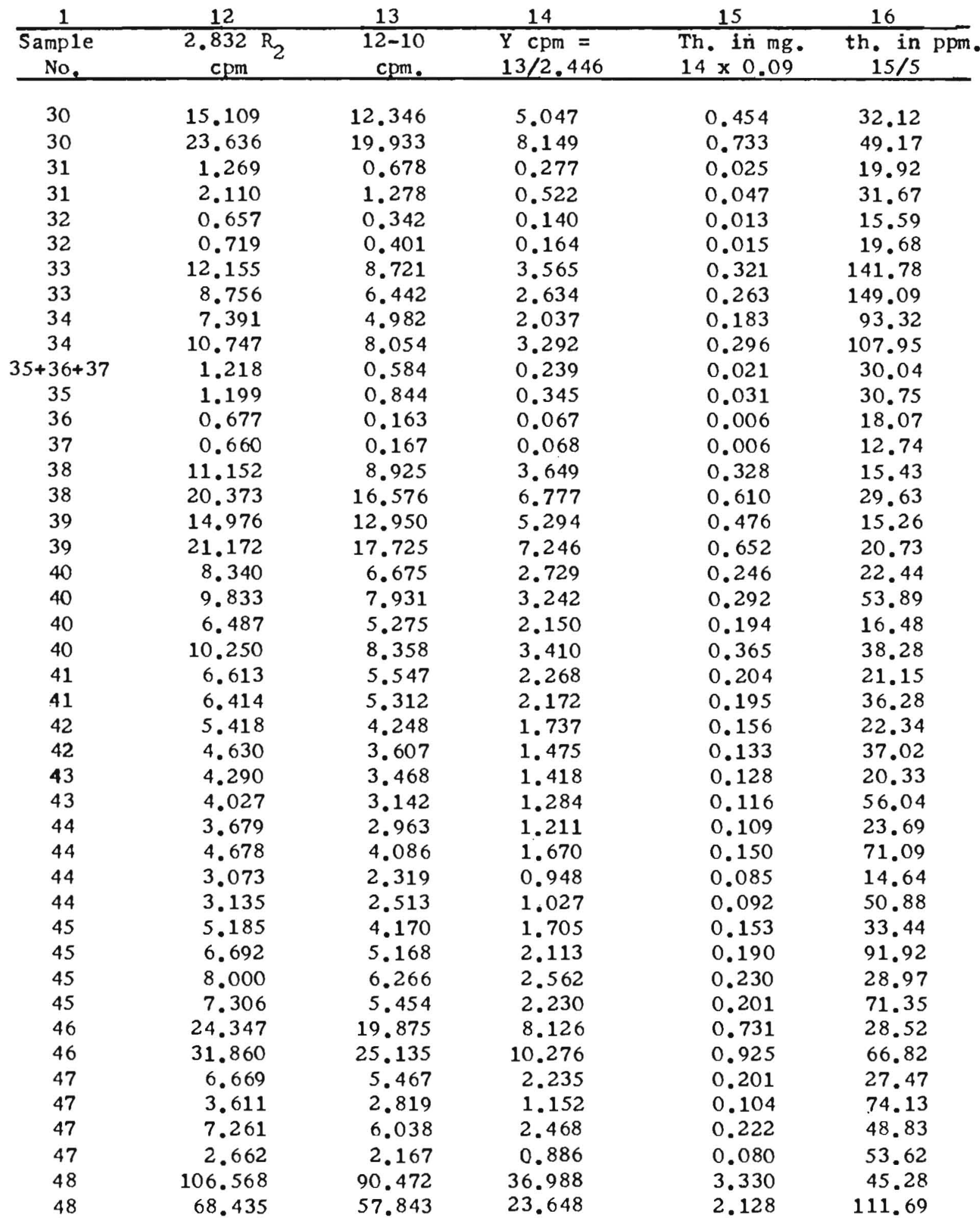


Table 1 (continued)

\begin{tabular}{|c|c|c|c|c|c|}
\hline 1 & 12 & 13 & 14 & 15. & 16 \\
\hline $\begin{array}{c}\text { Sample } \\
\text { No. }\end{array}$ & $\begin{array}{c}2.832 R_{2} \\
\mathrm{cpm} .\end{array}$ & $\begin{array}{r}12-10 \\
\mathrm{cpm}\end{array}$ & $\begin{array}{l}Y \mathrm{cpm}= \\
13 / 2,446\end{array}$ & $\begin{array}{l}\text { Th, in mg. } \\
14 \times 0,09 \\
\end{array}$ & $\begin{array}{c}\text { Th. in ppm } \\
15 / 5\end{array}$ \\
\hline 48 & 55.790 & 47.122 & 19.265 & 1.734 & 44.69 \\
\hline 48 & 18.130 & 16.342 & 6.681 & 0.601 & 43.42 \\
\hline 49 & 15.763 & 13.574 & 5.549 & 0.499 & 22.45 \\
\hline 49 & 12.466 & 10.101 & 4.130 & 0.372 & 41.69 \\
\hline 49 & 19.391 & 16.392 & 6.701 & 0.603 & 29.65 \\
\hline 49 & 21.472 & 18.907 & 7.730 & 0.696 & 81.65 \\
\hline 50 & 6.208 & 5.302 & 2.168 & 0.195 & 19.50 \\
\hline 50 & 5.123 & 4.248 & 1.737 & 0.156 & 35.50 \\
\hline 51 & 13.625 & 10.256 & 4.193 & 0.377 & 33.23 \\
\hline 52 & 43.669 & 33.888 & 13.850 & 1.247 & 39.90 \\
\hline 53 & 2.192 & 1.784 & 0.729 & 0.066 & 18.07 \\
\hline 53 & 3.350 & 2.839 & 1.161 & 0.104 & 26.88 \\
\hline 53 & 7.247 & 4.461 & 1.824 & 0.164 & 21.19 \\
\hline 53 & 9.844 & 6.931 & 2.834 & 0.255 & 31.83 \\
\hline 54 & 18.983 & 15.542 & 6.354 & 0.256 & 40.61 \\
\hline 54 & 44.247 & 35.503 & 14.515 & 1.306 & 92.42 \\
\hline 55 & 15.259 & 12.372 & 5.058 & 0.455 & 43.30 \\
\hline 55 & 3.602 & 2.815 & 1.151 & 0.103 & 95.64 \\
\hline 56 & 14.259 & 11.272 & 4.608 & 0.415 & 32.62 \\
\hline 56 & 3.279 & 2.629 & 1.075 & 0.097 & 81.65 \\
\hline 57 & 26.165 & 21.779 & 8.904 & 0.801 & 28.57 \\
\hline 57 & 9.379 & 7.700 & 3.148 & 0.283 & 62.22 \\
\hline 57 & 17.320 & 13.327 & 5.448 & 0.490 & 35.64 \\
\hline 57 & 4.511 & 3.646 & 1.491 & 0.134 & 87.93 \\
\hline 58 & 54.827 & 46.997 & 19.214 & 1.729 & 34.14 \\
\hline 58 & 69.925 & 58.922 & 24.089 & 2.168 & 85.78 \\
\hline 59 & 7.468 & 6.301 & 2.576 & 0.232 & 337.70 \\
\hline
\end{tabular}


Table 1 (contd.)

\begin{tabular}{|c|c|c|c|}
\hline 1 & 5 & 17 & 18 \\
\hline $\begin{array}{c}\text { Sample } \\
\text { No. }\end{array}$ & $\begin{array}{l}\text { Weight of } \\
\text { heavies in } \\
\text { size fraction. }\end{array}$ & $\begin{array}{l}\text { Weight of } \\
\text { sample in size } \\
\text { fraction } \mathrm{qm} \text {. }\end{array}$ & $\begin{array}{c}\text { Per cent heavies } \\
\text { in size fraction } \\
5 / 17\end{array}$ \\
\hline \multicolumn{4}{|c|}{ gan. } \\
\hline 1 & 2.301 & 6.33 & 36.35 \\
\hline 2 & 1.100 & 2.86 & 38.48 \\
\hline 2 & 1.390 & 3.64 & 38.17 \\
\hline $3+4$ & 4.516 & 8.02 & 56.25 \\
\hline 4 & 2.230 & 3.76 & 59.30 \\
\hline 5 & 7.319 & 12.55 & 58.30 \\
\hline$\tilde{\mathfrak{D}}$ & 10.676 & 12.80 & 83.40 \\
\hline 7 & 6.573 & 10.00 & 65.73 \\
\hline 8 & 0.465 & 21.93 & 2.12 \\
\hline 8 & 2.717 & 125.30 & 2.17 \\
\hline 9 & 3.925 & 151.30 & 2.59 \\
\hline 10 & 3.708 & 14.40 & 25.80 \\
\hline 11 & 1.038 & 28.40 & 3.65 \\
\hline 11 & 0.304 & 7.98 & 3.81 \\
\hline 12 & 0.058 & 1.90 & 3.05 \\
\hline 13 & 2.927 & 10.80 & 27.10 \\
\hline 13 & 2.076 & 11.30 & 18.37 \\
\hline 14 & 4.493 & 15.40 & 29.17 \\
\hline 14 & 2.806 & 10.50 & 26.72 \\
\hline 15 & 5.611 & 20.33 & 27.60 \\
\hline 15 & 2.883 & 11.80 & 24.43 \\
\hline 16 & 1.352 & 4.90 & 27.60 \\
\hline 16 & 0.832 & 3.41 & 24.43 \\
\hline 17 & 3.395 & 173.50 & 1.96 \\
\hline 17 & 3.686 & 202.20 & 1.82 \\
\hline 18 & 3.689 & 51.90 & 7.11 \\
\hline 18 & 3.079 & 72.00 & 4.28 \\
\hline 19 & 3.008 & 48.60 & 6.19 \\
\hline 18 & 1.942 & 47.50 & 10.40 \\
\hline 20 & 3.267 & 49.10 & 6.65 \\
\hline 20 & 1.985 & 19.20 & 10.34 \\
\hline 21 & 4.114 & 38.30 & 10.74 \\
\hline 21 & 4.960 & 21.00 & 23.62 \\
\hline
\end{tabular}


Table 1 - (contd.)

\begin{tabular}{|c|c|c|c|}
\hline 1 & 5 & 17 & 18 \\
\hline $\begin{array}{l}\text { Sample } \\
\text { No. }\end{array}$ & $\begin{array}{l}\text { Welght of } \\
\text { heavies in } \\
\text { size fraction } \\
\text { gm. }\end{array}$ & $\begin{array}{l}\text { Weight of } \\
\text { sample in size } \\
\text { fraction qm. }\end{array}$ & $\begin{array}{c}\text { Per cent heaviea } \\
\text { in size fraction } \\
5 / 17\end{array}$ \\
\hline 22 & 8.370 & 13.93 & 60.07 \\
\hline 22 & 8.090 & 10.71 & 75.50 \\
\hline 23 & 2.035 & 24.20 & 8.41 \\
\hline 24 & 2.035 & 24.20 & 8.41 \\
\hline 25 & 7.157 & 91.80 & 7.80 \\
\hline 26 & .848 & 11.60 & 7.31 \\
\hline 27 & 5.327 & 180.00 & 2.96 \\
\hline 27 & 8.041 & 94.10 & 8.54 \\
\hline 28 & 71.006 & 163.90 & 43.32 \\
\hline 28 & 37.906 & 219.60 & 17.26 \\
\hline 29 & 19.406 & 59.70 & 32.51 \\
\hline 29 & 20.836 & 59.39 & 35.08 \\
\hline 30 & 14.133 & 79.50 & 17.78 \\
\hline 30 & 14.908 & 95.40 & 15.63 \\
\hline 31 & 1.255 & 31.85 & 3.94 \\
\hline 31 & 1.484 & 24.10 & 6.16 \\
\hline 32 & .834 & 28.00 & 2.98 \\
\hline 32 & .762 & 30.12 & 2.53 \\
\hline 33 & 2.264 & 49.60 & 4.56 \\
\hline 33 & 1.764 & 62.11 & 2.84 \\
\hline 34 & 1.961 & 200.10 & 0.98 \\
\hline 34 & 2.742 & 73.30 & 3.74 \\
\hline $35+36+37$ & .699 & 191.50 & 0.36 \\
\hline 35 & 1.008 & 98.50 & 1.02 \\
\hline 36 & .332 & 85.13 & .39 \\
\hline 37 & .471 & 44.02 & 1.07 \\
\hline 38 & 21.252 & 180.10 & 11.80 \\
\hline 38 & 20.585 & 62.93 & 32.71 \\
\hline 39 & 31.193 & 267.30 & 11.67 \\
\hline 39 & 31.453 & 99.50 & 31.61 \\
\hline 40 & 10.963 & 37.10 & 29.55 \\
\hline 40 & 5.418 & 15.41 & 35.18 \\
\hline 40 & 11.708 & 64.63 & 18.12 \\
\hline 40 & 8.012 & 20.95 & 38.33 \\
\hline 41 & 9.643 & 28.12 & 34.29 \\
\hline 41 & 5.373 & 13.54 & 39.68 \\
\hline 42 & 6.982 & 35.28 & 19.83 \\
\hline 42 & 3.593 & 9.80 & 36.66 \\
\hline 43 & 6.295 & 37.89 & 16.60 \\
\hline 43 & 2.070 & 5.74 & 36.04 \\
\hline 44 & 4.601 & 19.42 & 23.71 \\
\hline
\end{tabular}


Table 1 (contd.)

\begin{tabular}{|c|c|c|c|}
\hline 1 & 5 & 17 & 18 \\
\hline $\begin{array}{c}\text { Sample } \\
\text { No. }\end{array}$ & $\begin{array}{l}\text { Weight of } \\
\text { heavies in } \\
\text { size fraction } \\
\text { gm. }\end{array}$ & $\begin{array}{l}\text { Welght of } \\
\text { sample in size } \\
\text { fraction qm. }\end{array}$ & $\begin{array}{c}\text { Per cent heavies } \\
\text { in size fraction } \\
5 / 17\end{array}$ \\
\hline 44 & 2.110 & 5.86 & 36.79 \\
\hline 44 & 5.804 & 61.11 & 9.99 \\
\hline 44 & 1.808 & 32.80 & 5.51 \\
\hline 45 & 4.575 & 22.93 & 20.77 \\
\hline 45 & 2.067 & 7.83 & 26.40 \\
\hline 45 & 7.938 & 55.79 & 14.23 \\
\hline 45 & 2.817 & 18.51 & 15.23 \\
\hline 46 & 25.633 & 100.62 & 25.48 \\
\hline 46 & 13.844 & 43.72 & 31.69 \\
\hline 47 & 7.318 & 39.18 & 18.67 \\
\hline 47 & 1.403 & 3.89 & 36.02 \\
\hline 47 & 4.546 & 25.40 & 17.90 \\
\hline 47 & 1.492 & 15.88 & 9.38 \\
\hline 48 & 73.536 & 92.96 & 79.64 \\
\hline 48 & 19.053 & 53.42 & 35.61 \\
\hline 48 & 38.802 & 64.27 & 60.34 \\
\hline 48 & 13.840 & 46.55 & 29.73 \\
\hline 49 & 22.227 & 119.81 & 18.55 \\
\hline 49 & 8.922 & 102.54 & 8.70 \\
\hline 49 & 20.307 & 106.10 & 19.10 \\
\hline 49 & 8.511 & 116.63 & 7.30 \\
\hline 50 & 10.000 & 82.73 & 12.09 \\
\hline 50 & 4.394 & 37.18 & 11.81 \\
\hline 51 & -- & $-\infty$ & $\cdots$ \\
\hline 51 & 11.334 & 23.60 & 48.01 \\
\hline 52 & $-\infty$ & $\infty$ & $\infty$ \\
\hline 52 & 31.311 & 66.00 & 47.44 \\
\hline 53 & 3.652 & 10.52 & 34.78 \\
\hline 53 & 3.869 & 5.37 & 72.05 \\
\hline 53 & 7.740 & 11.80 & 65.59 \\
\hline 53 & 8.010 & 10.12 & 79.13 \\
\hline 54 & 13.840 & 22.39 & 61.79 \\
\hline 54 & 14.131 & 20.43 & 69.16 \\
\hline 55 & 10.508 & 13.41 & 78.42 \\
\hline 55 & 1.077 & 1.60 & 67.31 \\
\hline 56 & 12.722 & 18.30 & 69.52 \\
\hline 56 & 1.888 & 1.99 & 59.40 \\
\hline 57 & 28.038 & 44.48 & 63.01 \\
\hline 57 & 4.548 & 7.77 & 58.56 \\
\hline 57 & 13.747 & 27.33 & 50.40 \\
\hline $\begin{array}{l}57 \\
58\end{array}$ & $\begin{array}{r}1.524 \\
50.638\end{array}$ & $\begin{array}{r}2.30 \\
105.82\end{array}$ & $\begin{array}{l}66.26 \\
47.85\end{array}$ \\
\hline
\end{tabular}


Table 1 (contd.)

\begin{tabular}{|c|c|c|c|}
\hline 1 & 5 & 17 & 18 \\
\hline $\begin{array}{c}\text { Sample } \\
\text { No. }\end{array}$ & $\begin{array}{l}\text { Weight of } \\
\text { heavies in } \\
\text { size fraction } \\
\mathrm{gm} .\end{array}$ & $\begin{array}{l}\text { Weight of } \\
\text { sample in size } \\
\text { fraction qm. }\end{array}$ & $\begin{array}{c}\text { Per cent heavies } \\
\text { in size fraction } \\
5 / 17\end{array}$ \\
\hline 58 & 25.275 & 50.37 & 40.18 \\
\hline 59 & 0.687 & 1.99 & 34.57 \\
\hline
\end{tabular}


A-2 Results of study of the direction of littoral drift in the vicinity of San Francisco bar

Table 2

\begin{tabular}{|c|c|c|c|c|c|c|}
\hline \multirow{3}{*}{$\begin{array}{l}\frac{1}{\text { Sample }} \\
\text { No. }\end{array}$} & \multirow{3}{*}{$\begin{array}{l}\frac{2}{\text { Surface }} \\
\text { or } \\
\text { deep }\end{array}$} & \multirow{3}{*}{$\frac{3}{\text { Location }}$} & \multirow{3}{*}{\begin{tabular}{l}
\multicolumn{4}{c}{ Size } \\
fraction \\
analyzed
\end{tabular}} & \multirow{3}{*}{$\begin{array}{l}5 \\
\text { Welght of } \\
\text { heavies in } \\
\text { size fraction } \\
\text { gm. }\end{array}$} & 6 & 7 \\
\hline & & & & & \multicolumn{2}{|c|}{$\begin{array}{l}\text { Correction } \\
\text { Coefficient }\end{array}$} \\
\hline & & & & & $\mathrm{C}_{1}$ & $\mathrm{C}_{2}$ \\
\hline 60 & SD & $\begin{array}{l}\text { Pacific Ocean } \\
\text { in vicinity of } \\
\text { San Francisco } \\
\text { Bar }\end{array}$ & 1 & 0.728 & 1.000 & 1.000 \\
\hline 61 & SD & $"$ & 1 & 2.339 & 1.000 & 1.000 \\
\hline 62 & $\mathrm{SD}$ & $"$ & 1 & 1.974 & 1.000 & 1.000 \\
\hline 63 & SD & $"$ & 1 & 1.518 & 1.000 & 1.000 \\
\hline 64 & $\mathrm{SD}$ & $"$ & 1 & 1.276 & 1.000 & 1.000 \\
\hline 65 & $\mathrm{SD}$ & $"$ & 1 & 37.844 & 0.871 & 0.695 \\
\hline 66 & $\mathrm{SD}$ & $" 1$ & 1 & 2.446 & 1.000 & 1.000 \\
\hline 67 & $\mathrm{SD}$ & $n$ & 1 & 3.587 & 1.000 & 1.000 \\
\hline 68 & $\mathrm{SD}$ & $" 1$ & 1 & 21.283 & 0.940 & 0.845 \\
\hline 69 & SD & $"$ & 1 & 8.627 & 1.000 & 1.000 \\
\hline
\end{tabular}


A - 2 Results of study of the direction of Iittoral drift in the vicinity of San Francisco bar

Table 2 (contd .)

\begin{tabular}{crccc}
1 & 8 & 9 & 10 & 11 \\
\hline $\begin{array}{c}\text { Sample } \\
\text { No. }\end{array}$ & $\begin{array}{c}\text { Net counting rate cpm. } \\
0.188 \mathrm{mev} . \\
0.238 \mathrm{mev} \\
\mathrm{R}_{1}\end{array}$ & $\begin{array}{c}\text { Corrected counting rate cpm. } \\
\mathrm{R}_{2}\end{array}$ & $\begin{array}{c}0.188 \mathrm{mev} . \\
\mathrm{R}_{1}=8 / 6\end{array}$ & $\begin{array}{c}0.238 \mathrm{mev} . \\
\mathrm{R}_{2}=9 / 7\end{array}$ \\
\hline 60 & 0.300 & 0.309 & 0.300 & 0.309 \\
61 & 0.207 & 0.417 & 0.207 & 0.417 \\
62 & 0.419 & 0.492 & 0.419 & 0.492 \\
63 & 0.402 & 0.529 & 0.402 & 0.529 \\
64 & 0.644 & 0.831 & 0.644 & 0.831 \\
65 & 32.196 & 54.393 & 36.964 & 78.263 \\
66 & .582 & .886 & .582 & .886 \\
67 & .724 & 1.071 & .724 & 1.071 \\
68 & 17.172 & 33.420 & 18.268 & 39.550 \\
69 & 2.766 & 4.847 & 2.766 & 4.847
\end{tabular}


A - 2 Results of study of the direction of littoral drift in the vicinity of San Prancisco bar

Table 2 (continued)

\begin{tabular}{|c|c|c|c|c|c|}
\hline 1 & 12 & 13 & 14 & 15 & 16 \\
\hline $\begin{array}{l}\text { Sample } \\
\text { No. }\end{array}$ & $\begin{array}{cc}2.832 & R_{2} \\
c p m . & \\
\end{array}$ & $\begin{array}{r}12-10 \\
\mathrm{cpm} .\end{array}$ & $\begin{array}{l}Y \mathrm{cpm} .= \\
12 / 2.446\end{array}$ & $\begin{array}{l}\text { Th. in mg. } \\
14 \times 0.09\end{array}$ & $\begin{array}{c}\text { Th, in } \mathrm{ppm} . \\
15 / 5\end{array}$ \\
\hline 60 & 0.875 & 0.575 & 0.235 & 0.021 & 28.84 \\
\hline 61 & 1.181 & 0.974 & 0.398 & 0.036 & 15.39 \\
\hline 62 & 1.393 & 0.974 & 0.398 & 0.036 & 18.24 \\
\hline 63 & 1.498 & 1.096 & 0.448 & 0.040 & 26.35 \\
\hline 64 & 2.353 & 1.709 & 0.699 & 0.063 & 49.37 \\
\hline 65 & 221.641 & 184.677 & 75.502 & 6.795 & 179.55 \\
\hline 66 & 2.509 & 1.927 & 0.788 & 0.071 & 29.03 \\
\hline 67 & 3.033 & 2.309 & 0.944 & 0.085 & 23.70 \\
\hline 68 & 112.006 & 93.738 & 38.323 & 3.449 & 162.05 \\
\hline 69 & 13.727 & 10.961 & 4.481 & 0.403 & 46.71 \\
\hline
\end{tabular}


A 2 Results of study of the direction of littoral drift in the vicinity of San Francisco bar

Table 2 (contd.)

\begin{tabular}{cccc}
1 & 5 & 17 & 18 \\
\hline $\begin{array}{c}\text { Sample } \\
\text { No. }\end{array}$ & $\begin{array}{l}\text { Weight of } \\
\text { heavieg in } \\
\text { gize fraction } \\
\text { gm. }\end{array}$ & $\begin{array}{l}\text { Weight of } \\
\text { gample in size } \\
\text { fraction qm }\end{array}$ & $\begin{array}{c}\text { Per cent heavies } \\
\text { in size fraction } \\
5 / 17\end{array}$ \\
\hline & & & \\
60 & 0.728 & 58.90 & 1.23 \\
61 & 3.339 & 86.90 & 2.69 \\
62 & 1.974 & 86.90 & 2.27 \\
63 & 1.518 & 40.00 & 3.79 \\
64 & 1.276 & 17.50 & 7.29 \\
65 & 37.844 & 86.20 & 43.90 \\
66 & 2.446 & 60.50 & 4.04 \\
67 & 3.587 & 64.40 & 5.57 \\
68 & 21.283 & 80.00 & 26.60 \\
69 & 8.627 & 43.30 & 19.92
\end{tabular}


B-1 Results of the study of the variation in thorlum along a profile

Table 3

\begin{tabular}{|c|c|c|c|c|c|c|}
\hline 1 & 2 & 3 & 4 & 5 & 6 & 7 \\
\hline \multirow[t]{2}{*}{$\begin{array}{l}\text { Sample } \\
\text { No. }\end{array}$} & \multirow{2}{*}{$\begin{array}{l}\text { Surface } \\
\text { or } \\
\text { deep }\end{array}$} & \multirow[t]{2}{*}{ Location } & \multirow{2}{*}{$\begin{array}{l}\text { Size } \\
\text { fraction } \\
\text { analyzed }\end{array}$} & \multirow{2}{*}{$\begin{array}{l}\text { Weight of } \\
\text { heaviet in } \\
\text { size fraction } \\
\text { gm. }\end{array}$} & \multicolumn{2}{|c|}{$\begin{array}{l}\text { Correction } \\
\text { Coefficient }\end{array}$} \\
\hline & & & & & $\mathrm{C}_{1}$ & $\mathrm{C}_{2}$ \\
\hline $\mathbf{a}$ & $S$ & $\begin{array}{l}\text { Location No, } \\
30,140^{8}\end{array}$ & 1 & 39.174 & 0.867 & 0.690 \\
\hline b & $\mathbf{S}$ & $\begin{array}{l}\text { Location No. } \\
30,180^{\prime}\end{array}$ & 1 & 4.912 & 1.000 & 1.000 \\
\hline c & 5 & $\begin{array}{l}\text { Location No. } \\
30,205^{\prime}\end{array}$ & 1 & 10.393 & 0.995 & 0.995 \\
\hline d & $\mathbf{S}$ & $\begin{array}{l}\text { Location } \mathrm{Na} \text {. } \\
30,220^{\prime}\end{array}$ & 1 & 5.749 & 1.000 & 1.000 \\
\hline $\mathbf{e}$ & $\mathbf{S}$ & $\begin{array}{l}\text { Location No. } \\
30,250^{\prime}\end{array}$ & 1 & 10.334 & 0.995 & 0.995 \\
\hline $\mathbf{f}$ & $\mathbf{S}$ & $\begin{array}{l}\text { Loceation No. } \\
30,280^{\prime}\end{array}$ & 1 & 7.735 & 1.000 & 1.000 \\
\hline$g$ & $\mathbf{s}$ & $\begin{array}{l}\text { Location No. } \\
30,310^{\prime}\end{array}$ & 1 & 0.858 & 1.000 & 1.000 \\
\hline h & $\mathbf{s}$ & $\begin{array}{l}\text { Locition No. } \\
30,325^{\prime}\end{array}$ & 1 & 6.963 & 1.000 & 1.000 \\
\hline
\end{tabular}


B - 1 Results of the study of the variation in thorium along a profile

Table 3 (contd.)

\begin{tabular}{ccccc}
1 & 8 & 9 & 10 & 11 \\
\hline $\begin{array}{c}\text { Sample } \\
\text { No. }\end{array}$ & $\begin{array}{c}\text { Net counting rate cpm. } \\
0.188 \mathrm{mev} . \\
\mathrm{R}_{1}\end{array}$ & $\begin{array}{c}0.238 \mathrm{mev} . \\
\mathrm{R}_{2}\end{array}$ & $\begin{array}{c}\text { Corrected counting rate cpm. } \\
0.188 \mathrm{mev} . \\
\mathrm{R}_{1}=8 / 6\end{array}$ & $\begin{array}{c}0.238 \mathrm{mev} . \\
\mathrm{R}_{2}=9 / 7\end{array}$ \\
\hline a & 22.894 & 32.106 & 26.406 & 46.530 \\
b & 2.282 & 3.925 & 2.293 & 3.945 \\
c & 1.639 & 2.551 & 1.639 & 2.551 \\
d & 1.987 & 3.184 & 1.997 & 3.200 \\
e & 1.287 & 1.912 & 1.287 & 1.912 \\
f & 0.516 & 0.461 & 0.516 & 0.461 \\
g & 1.961 & 2.872 & 1.961 & 2.872 \\
h & 1.456 & 2.396 & 1.456 & 2.396
\end{tabular}


B - 1 Results of the study of the variation in thorium along a profile

Table 3 (continued)

\begin{tabular}{|c|c|c|c|c|c|}
\hline 1 & 12 & 13 & 14 & 15 & 16 \\
\hline $\begin{array}{l}\text { Sample } \\
\text { No. }\end{array}$ & $\begin{array}{cc}2.832 & R_{2} \\
\mathrm{cpm} . & \end{array}$ & $\begin{array}{r}12-10 \\
\mathrm{cpm} .\end{array}$ & $\begin{array}{l}\text { Y cpm. }= \\
13 / 2,446\end{array}$ & $\begin{array}{l}\text { Th. in } \mathrm{mg} \text {. } \\
14 \times 0.09\end{array}$ & $\begin{array}{c}\text { Th. in ppm. } \\
15 / 5\end{array}$ \\
\hline a & 131.773 & 105.367 & 43.077 & 3.877 & 98.97 \\
\hline$b$ & 11.172 & 8.879 & 3.630 & 0.327 & 31.46 \\
\hline$c$ & 7.224 & 5.585 & 2.395 & 0.216 & 37.57 \\
\hline d & 9.062 & 7.065 & 2.888 & 0.260 & 25.16 \\
\hline e & 5.415 & 4.228 & 1.728 & 0.155 & 20.04 \\
\hline $\mathrm{f}$ & 1.306 & 0.790 & 0.323 & 0.029 & 33.80 \\
\hline g & 8.133 & 6.172 & 2.523 & 0.227 & 32.60 \\
\hline h & 6.785 & 5.329 & 2.179 & 0.196 & 39.40 \\
\hline
\end{tabular}


B - 1 Results of the study of the variation in thorium along a profile

Table 3 (contd.)

\begin{tabular}{cllc}
1 & 5 & 17 & 18 \\
\hline $\begin{array}{c}\text { Sample } \\
\text { No. }\end{array}$ & $\begin{array}{l}\text { Weight of } \\
\text { heavies in } \\
\text { size fraction } \\
\text { gm. }\end{array}$ & $\begin{array}{l}\text { Weight of } \\
\text { samples in size }\end{array}$ & $\begin{array}{c}\text { Per cent heavies } \\
\text { in size fraction qm. }\end{array}$ \\
\hline
\end{tabular}

$\begin{array}{lrrr}\text { a } & 39.174 & 83.37 & 46.99 \\ \text { b } & 10.393 & 49.49 & 21.00 \\ \text { c } & 5.749 & 35.95 & 15.99 \\ \text { d } & 10.334 & 44.93 & 23.00 \\ \text { e } & \mathbf{7 . 7 3 5} & 50.83 & 15.22 \\ \text { f } & 0.858 & 4.44 & 19.30 \\ \text { g } & 6.963 & 40.34 & 17.36 \\ \text { h } & 4.975 & 24.81 & 20.05\end{array}$


C-1 Results of the study of the variation in thorium concentration with time at a certain location

\section{Table 4}

\begin{tabular}{|c|c|c|c|c|c|c|c|}
\hline \multirow[t]{2}{*}{$\begin{array}{c}\text { Sample } \\
\text { No. }\end{array}$} & \multirow[t]{2}{*}{$\begin{array}{l}\text { Date of } \\
\text { Collection }\end{array}$} & \multirow{2}{*}{$\begin{array}{c}\text { Surface } \\
\text { or } \\
\text { Deep }\end{array}$} & \multirow[t]{2}{*}{ Location } & \multirow{2}{*}{$\begin{array}{l}\text { Size } \\
\text { fraction } \\
\text { analyzed }\end{array}$} & \multirow{2}{*}{$\begin{array}{l}\text { Weight of } \\
\text { heavies } \\
\text { size } \\
\text { fraction }\end{array}$} & \multicolumn{2}{|c|}{$\begin{array}{l}\text { Correction } \\
\text { coefficient }\end{array}$} \\
\hline & & & & & & $\mathrm{C}_{1}$ & $\mathrm{C}_{2}$ \\
\hline $\mathbf{a}$ & $6 / 18 / 61$ & $\mathbf{S}$ & Fleishhacker & 1 & 19.053 & 0.950 & 0.871 \\
\hline a & $6 / 18 / 61$ & $\mathrm{D}$ & $"$ & 1 & 13.840 & 0.975 & 0.945 \\
\hline b & $1 / 10 / 61$ & $\mathbf{S}$ & $"$ & 1 & 4.913 & 1.000 & 1.000 \\
\hline c & $12 / 2 / 61$ & $\mathbf{S}$ & $"$ & 1 & 18.296 & 0.950 & 0.880 \\
\hline c & $12 / 2 / 61$ & $\mathrm{D}$ & $"$ & 1 & 23.796 & 0.925 & 0.815 \\
\hline d & $12 / 18 / 61$ & $\mathbf{S}$ & $"$ & 1 & 10.317 & 1.000 & 1.000 \\
\hline d & $12 / 18 / 61$ & $\mathbf{D}$ & $"$ & 1 & 9.980 & 1.000 & 1.000 \\
\hline
\end{tabular}




\section{C - 1 Results of the study of the variation in thorium con- centration with time at a certain location}

Table 4 (contd.)

\begin{tabular}{ccccc}
1 & 8 & 9 & 10 & 11 \\
\hline $\begin{array}{c}\text { Sample } \\
\text { No. }\end{array}$ & $\begin{array}{c}\text { Net counting rate cpm. } \\
0.188 \mathrm{mev} \\
\mathrm{R} 1\end{array}$ & $\begin{array}{c}0.238 \mathrm{mev} \\
\mathrm{R} 2\end{array}$ & $\begin{array}{c}\text { Corrected counting rate cpm. } \\
0.188 \mathrm{mev} . \\
\mathrm{R}_{1}-8 / 6\end{array}$ & $\begin{array}{c}0.238 \mathrm{mev} . \\
\mathrm{R}_{2}=9 / 7\end{array}$ \\
\hline a & 10.062 & 21.048 & 10.592 & 24.165 \\
$\mathrm{a}$ & 2.718 & 6.050 & 2.788 & 6.402 \\
$\mathrm{~b}$ & 1.109 & 2.098 & 1.109 & 2.098 \\
$\mathrm{c}$ & 4.707 & 8.433 & 4.952 & 9.583 \\
$\mathrm{c}$ & 7.795 & 12.487 & 8.427 & 15.321 \\
$\mathrm{~d}$ & 4.183 & 5.531 & 4.183 & 5.531 \\
$\mathrm{~d}$ & 5.307 & 8.901 & 5.307 & 8.901
\end{tabular}


C - 1 Results of the study of the variation in thorium concentration with time at a certain location

Table 4 (continued)

\begin{tabular}{cccccc}
1 & 12 & 13 & 14 & 15 & 16 \\
\hline $\begin{array}{c}\text { Sample } \\
\text { No. }\end{array}$ & $\begin{array}{c}2.832 \\
c p m_{2}\end{array}$ & $\begin{array}{r}12-10 \\
\text { cpm. }\end{array}$ & $\begin{array}{c}\text { Y-cpm. } \\
13 / 2.446\end{array}$ & $\begin{array}{c}\text { Th. in mg. } \\
14 \times 0.09\end{array}$ & $\begin{array}{c}\text { Th. in ppm } \\
15 / 5\end{array}$ \\
\hline a & 68.435 & 57.843 & 23.648 & 2.128 & 111.69 \\
a & 18.130 & 15.342 & 6.272 & 0.564 & 40.75 \\
b & 5.941 & 4.832 & 1.975 & 0.178 & 36.23 \\
c & 27.139 & 22.187 & 9.071 & 0.816 & 44.60 \\
c & 43.389 & 34.962 & 14.293 & 1.286 & 54.04 \\
d & 15.664 & 11.481 & 4.694 & 0.422 & 40.90 \\
d & 25.208 & 19.901 & 8.136 & 0.732 & 73.35
\end{tabular}



C-1 Result of the study of the variation in thorium con-
centration with time at a certain location

Table 4 (contd.)

\begin{tabular}{cccc}
1 & 5 & 17 & 18 \\
$\begin{array}{c}\text { Sample } \\
\text { No. }\end{array}$ & $\begin{array}{l}\text { Weight of } \\
\text { heavies in } \\
\text { size fraction } \\
\text { gm. }\end{array}$ & $\begin{array}{l}\text { Weight of } \\
\text { sample in alze } \\
\text { fraction qm. }\end{array}$ & $\begin{array}{c}\text { Per cent heavies } \\
\text { in size fraction } \\
5 / 17\end{array}$ \\
\hline a & 19.053 & 53.42 & 35.61 \\
a & 13.840 & 46.55 & 29.73 \\
b & 4.913 & 13.40 & 36.66 \\
c & 18.296 & 47.03 & 38.90 \\
C & 23.796 & 38.90 & 61.17 \\
d & 10.317 & 23.96 & 43.06 \\
d & 9.980 & 16.94 & 58.90
\end{tabular}


BEACH GROSION BOARD, C.E., U.S. ARMY, WASH., D.C. LTTTORAL STUDIBS NEAR SAN PRANCISCO USING TRACER TRCHNIQUZS by Ade $1 M$. Kame1, November 1962 $86 \mathrm{pp} ., 24$ illus., 6 tables, and 4 appendices TBCHNICAL MBMORANDUM No. 131 UNCLASSIPIED
1. Sed. Transport by waves \& currents 2. Tracers Radioactive

3. Ca1ifornia Lit tora 1 drift I. Kame1, A, M
A me thod of assaying naturally radioactive thoriun for detecting the direction of littoral drift along a coast was investigated and applied to the California
coast $f$ rom the Russian River mouth to Point San Pedro. The rethed proved to be very quick for gualitative results and rather simple compared to mineralogical analysis. The liong the cosst under study. Heavy winesals feep $\$ 2$ mples along the coast under study. heavy alnerals for a 1 imited size fractlon of the sand samples were separated and radioctivity present coot pectione ter $0.118 \mathrm{Mev}$. peak from Ra226 in the uranium series.
BEACH EROSION BOARD, C. B., U.S. ARMY, WASH., D.C.

LITTORAL STUDIES NEAR SAN PRANCINCO US ING TRACBR TBCHNIQUES by Ade $1 \mathrm{M}$. Kame 1 , November 1962 86 pp., 24 111us., 6 tables, and 4 appendices

TBCHNICAL MEMORANDUM No. 131 UNCLASSIPIED

A method of assaying naturally radioactive thorium for detecting the direction of littoral drift along a coast was investigated and applied to the California coast from the Russian River mouth to Point San Pedro. The method proved to be very quick for qualitative results and rather simple compared to mineralogical analysis. The method involved collection of surface and deep samples a long the coast under study. Heavy minerals for a $1 \mathrm{imited}$ size fraction of the sand samples were separated and radioactivity present counted by use of a 2-channel gama-rap spectrometer. One channel was adjusted on the 0.238 Mev. peak from $\mathrm{Pb}^{212}$ in the thorlum series and the other on the $0.118 \mathrm{Mev}$. peax from $\mathrm{Ra} 226$ in the uranium series.
BEACH BROSION BOARD, C. B., U. S. ARMY, MASH., D.C.

LITTORAL STUDIES NBAR SAN PRANCISCO USING TRACBR THCHNIQUBS by Ade1 M. Kame 1, November 1962 86 pp.. 24 illus., 6 tables, and 4 appendices

TBCHNICAL MRMORANDUM No. 131 UNCLASSIPIBD

A me thod of assaying naturally radioactive thorium for detecting the direction of 1it toral drift along const was investigated and applied to the Callifornia cosst from the Russian River mouth to Point San Perro. The wethod proved to be very quick for qualitative results and rather simple compared to mineralogical analysis The method involved collection of surface and deep samples long the const under study. Heavy minerals for a 1 imited size fraction of the sand samples vere separated and radioactivity present counted by uee of a 2-channel gama-ray spectrometer. One channe 1 was adjusted on the 0.238 Mev. penk from $P_{b} 212$ in the thorlum serles and the other on the $0.118 \mathrm{Mev}$. pear from Ra 226 in the uranium series.
1. Sed. Transport by

2. Tracers Tracers -

3. California Lit toral drift I. Kame $1, A$. $M$. ii. Tit1e

sis

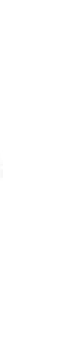

